Portland State University

PDXScholar

$11-22-1982$

\title{
The Effect of Dwarf Mistletoe (Arceuthobium americanum) Upon a Portion of the Carbon Budget of Lodgepole Pine (Pinus contorta)
}

Nancy Ellen Broshot

Portland State University

Follow this and additional works at: https://pdxscholar.library.pdx.edu/open_access_etds

Part of the Biology Commons, Ecology and Evolutionary Biology Commons, and the Plant Biology Commons

Let us know how access to this document benefits you.

\section{Recommended Citation}

Broshot, Nancy Ellen, "The Effect of Dwarf Mistletoe (Arceuthobium americanum) Upon a Portion of the Carbon Budget of Lodgepole Pine (Pinus contorta)" (1982). Dissertations and Theses. Paper 3138. https://doi.org/10.15760/etd.3130

This Thesis is brought to you for free and open access. It has been accepted for inclusion in Dissertations and Theses by an authorized administrator of PDXScholar. Please contact us if we can make this document more accessible: pdxscholar@pdx.edu. 
AN ABSTRACT FOR THE THESIS OF Nancy Ellen Broshot for the Master of Science in Biology presented November 23, 1982.

Title: The Effect of Dwarf Mistletoe (Arceuthobium americanum) upon a Portion of the Carbon Budget of Lodgepole Pine (Pinus contorta).

APPROVED BY MEMBERS OF THE THESIS COMMITTEE:
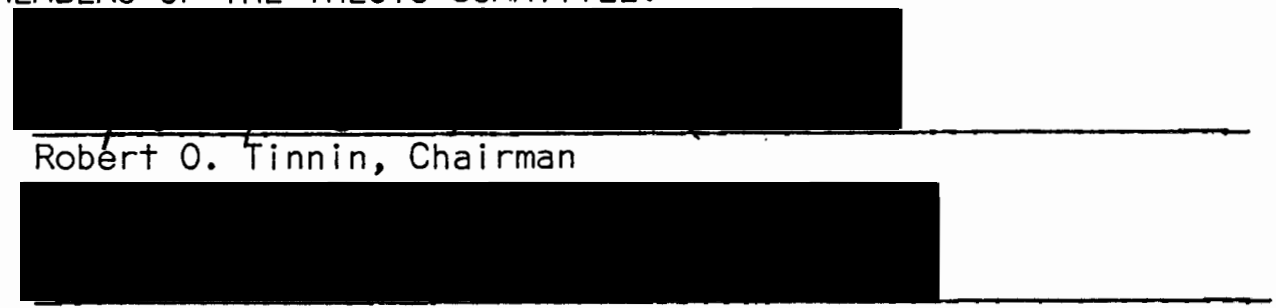

Richard D. Tocher
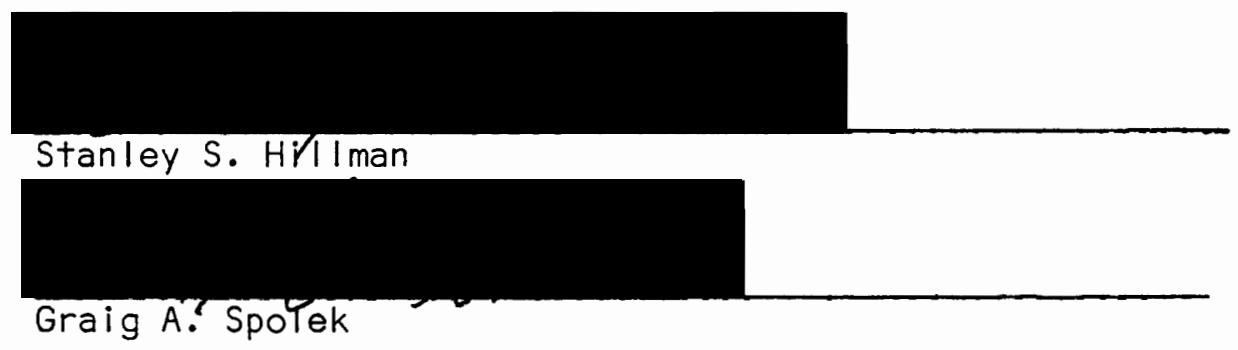

Arceuthobium americanum is a vascular plant which is parasitic upon Pinus contorta var. murrayana. Its documented effects include reductions in host growth, vigor and wood quality. The specific physiological changes that occur in the host are, for the most part, unknown.

In an attempt to understand the manner in which the mistletoe alters its host's carbon budget, a model is proposed which states that the host plant has priorities for carbon allocation. The model 
proposes that the parasite will access the host's carbon initially in terms of carbon intended for storage, next, in terms of carbon intended for growth, and finally, in terms of carbon allocated for respiration. If the model is accurate, then the presence of the parasite will initially be reflected in decreased amounts of stored carbon (i.e. starch), next, in decreased host growth (i.e. biomass allocation), and finally, by the death of the host.

To determine the accuracy of the proposed model, starch concentrations and several physical characteristics of uninfected and variously infected host trees were examined.

Physical characteristics which were altered as a result of dwarf mistletoe infection include needle number, mean needle length, needle biomass, mass per needle, total needle length and surface area, twig length, twig biomass, and twig unit mass. In general, the effect of the mistletoe was to decrease the annual allocation of carbon to infected tissues. This is what is predicted by the model.

The concentration of starch in infected tissues was found to be as much as 15 times that found in comparable uninfected tissues. This seems to be contradictory to the proposed model.

In terms of carbon budgets for branches, the proposed model was found to be inaccurate. Although the amount of carbon being allocated for biomass decreased, the concentration of starch in infected host tissues increased. However, in terms of the accuracy of the model for the entire tree, more work needs to be done. Work on whole tree biomass allocation has shown decreasing trends, however, no work has yet been done on entire tree starch concentrations. 
THE EFFECT OF DWARF MISTLETOE (ARCEUTHOBIUM AMERICANUM) UPON A PORTION OF THE CARBON BUDGET OF LODGEPOLE PINE (PINUS CONTORTA)

by

NANCY ELLEN BROSHOT

A thesis submitted in partial fulfillment of the requirements for the degree of

MASTER OF SCIENCE

in

BIOLOGY

Portland State University

1982 
TO THE OFFICE OF GRADUATE STUDIES AND RESEARCH:

The members of the Committee approve the thesis of Nancy Ellen Broshot presented November 22, 1982.

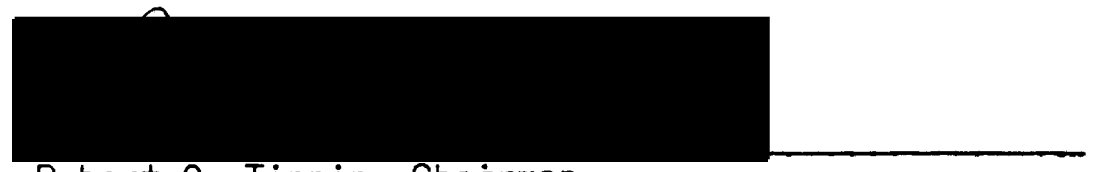

Robert 0. Tinnin, Chairman

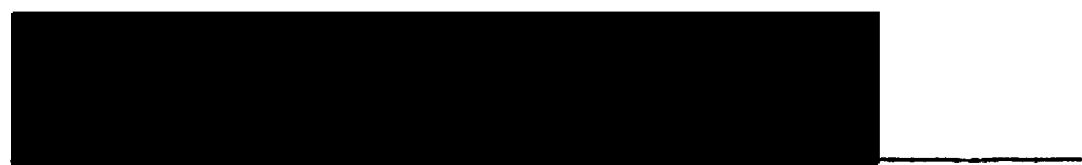

Richard D. Tocher

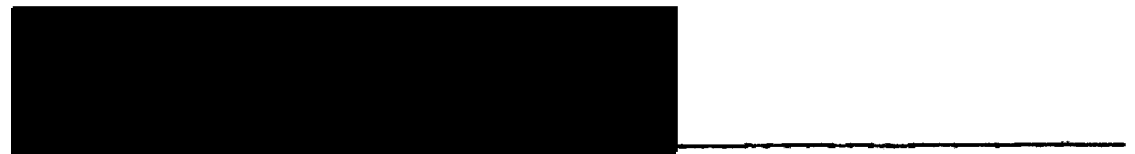

Stanley S. Hixlman

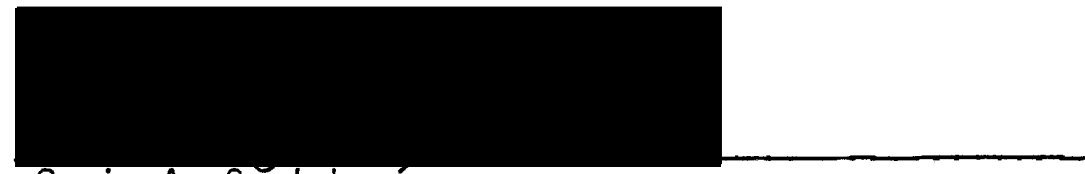

Graig A. Spolek

APPROVED:

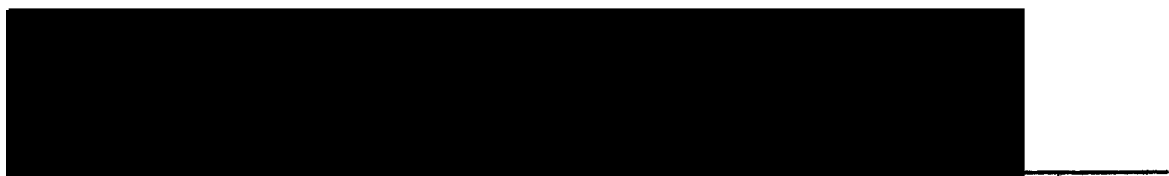

W. Herman Taylor, Head, Department of Biology

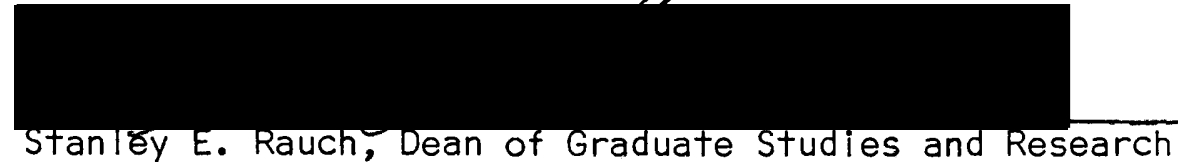




\section{ACKNOWLEDGEMENTS}

I wish to extend gratitude to all the members of my committee for their assistance: Richard Tocher, Stan Hillman, and especially, Robert Tinnin, for his unlimited patience and understanding.

Many thanks to Phil Withers for his invaluable assistance with computer programming, and for always answering all of my dumb questions.

I wish to thank all the people who helped and advised me: Steve Gustofson, Warren Webb, and Don Knutson at Oregon State University; Mary Taylor at Portland State University.

I'd I ike to thank the people who helped me collect my samples, especially Jim Campbell and Lee Kirkpatrick.

I wish to acknowledge the financial support that Dr Tinnin received through the Research and Publication Committee of Portland State University that helped provide equipment. I'd additionally like to acknowledge the financial support given to me by the Biology Department.

I also thank everyone who helped through their moral support, especially my husband, Morgan Hamilton, without whose help and understanding, none of this would have been possible. 
ACKNOWLEDGEMENTS $\ldots \ldots \ldots \ldots \ldots \ldots \ldots \ldots \ldots \ldots \ldots \ldots \ldots \ldots \ldots \ldots \ldots$

LIST OF TABLES $\ldots \ldots \ldots \ldots \ldots \ldots \ldots \ldots \ldots \ldots \ldots \ldots \ldots \ldots \ldots \ldots \ldots \ldots \ldots \ldots \ldots \ldots$

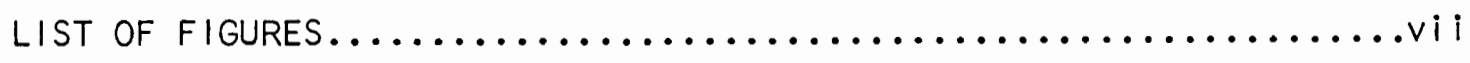

INTRODUCTION.......................................

The carbon budget of the host.................... 7

The proposed research...........................

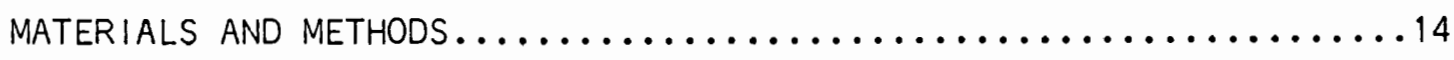

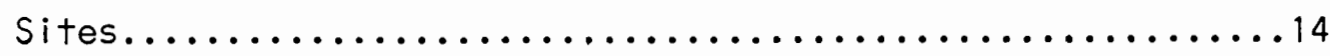

Measurements of twig samples...................... 15

Preparation of starch samples..................... 16

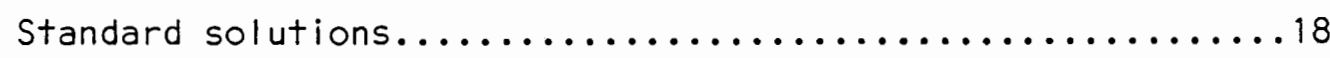

Chemical analysis of samples......................

Statistical analysis................................

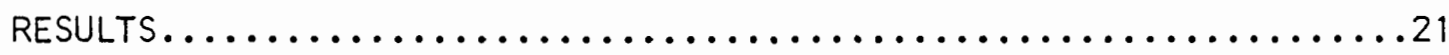

Physical features vs DMR (Dwarf Mistletoe Rating).........24

Physical features vs BRS (infection class).............27

Starch concentration VS DMR and BRS (infection class)......33

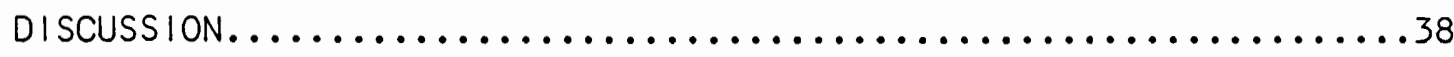

Starch....................................

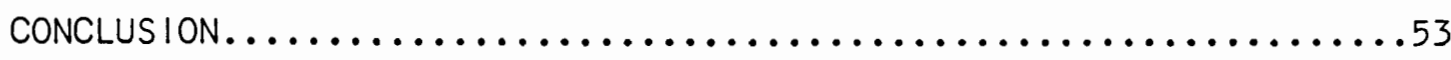

LITERATURE CITED.................................... 54

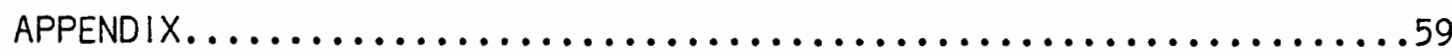




\section{LIST OF TABLES}

TABLE

PAGE

I Crescent Lake tree characteristics................. 22

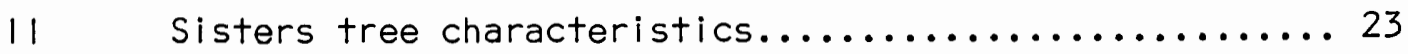

111 The effect of DMR (Dwarf Mistletoe Rating) system

on needle characteristics...................... 25

IV The effect of DMR on twig characteristics...........26

$\checkmark \quad$ The effect of branch rating on needle characteristics... 28

VI The effect of branch rating on twig characteristics.... 29

VII Infection class vs needle characteristics........... 31

VIII Infection class vs twig characteristics..............32

IX DMR vs starch concentration ( $\%$ dry mass).................

$X \quad$ Infection class vs starch concentration ( $\%$ dry mass).....35

XI Summary of the effects of dwarf mistletoe upon its host...37

XII DMR vs needle biomass $(g) \ldots \ldots \ldots \ldots \ldots \ldots \ldots \ldots \ldots \ldots \ldots \ldots . \ldots \ldots \ldots$

$x \mid 11 \quad$ DMR $v$ s number of needles.....................62

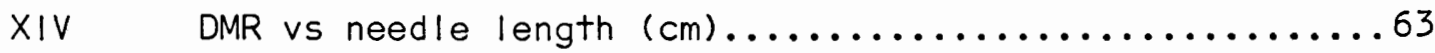

XV DMR vs mass per needle $(\mathrm{mg}) \ldots \ldots \ldots \ldots \ldots \ldots \ldots \ldots \ldots$

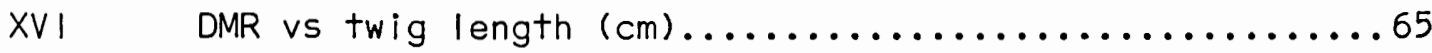

XVII $\quad$ DMR vs twig biomass $(g) \ldots \ldots \ldots \ldots \ldots \ldots \ldots \ldots \ldots \ldots \ldots \ldots \ldots \ldots \ldots$

XVIII DMR vs twig unit mass $(m g) \ldots \ldots \ldots \ldots \ldots \ldots \ldots \ldots \ldots \ldots$

XIX DMR vs radial increment.....................68

XX Branch rating vs number of needles...............69 
TABLE

PAGE

XXI Branch rating vs needle length $(\mathrm{cm}) \ldots \ldots \ldots \ldots \ldots \ldots$

XXII Branch rating vs needle biomass $(g) \ldots \ldots \ldots \ldots \ldots \ldots \ldots$

XXIII Branch rating vs mass per needle $(\mathrm{mg}) \ldots \ldots \ldots \ldots \ldots \ldots$

XXIV Branch rating vs total needle length $(\mathrm{cm}) \ldots \ldots \ldots \ldots . . . .73$

XXV Branch rating vs total needle surface area $\left(\mathrm{cm}^{2}\right) \ldots \ldots . .74$

XXVI Branch rating vs twig length $(\mathrm{cm}) \ldots \ldots \ldots \ldots \ldots \ldots$

XXV $11 \quad$ Branch rating vs twig biomass $(g) \ldots \ldots \ldots \ldots \ldots \ldots$

XXVIII Branch rating vs twig unit mass $(m g) \ldots \ldots \ldots \ldots \ldots \ldots$

XXIX Infection class vs number of needles...............78

KXX Infection class vs needle length $(\mathrm{cm}) \ldots \ldots \ldots \ldots \ldots \ldots$

XXXI Infection class vs needle biomass $(g) \ldots \ldots \ldots \ldots \ldots$

XXXII Infection class vs mass per needle (mg)............81

$X X X|1|$ Infection class vs total needle length $(\mathrm{cm}) \ldots \ldots \ldots . . .82$

XXXIV Infection class vs total needle surface area $\left(\mathrm{cm}^{2}\right) \ldots \ldots 83$

XXXV Infection class vs twig length $(\mathrm{cm}) \ldots \ldots \ldots \ldots \ldots \ldots$

XXXVI Infection class vs twig biomass $(g) \ldots \ldots \ldots \ldots \ldots$

XXXVII Infection class vs twig unit mass $(m g) \ldots \ldots \ldots \ldots . \ldots 86$

XXXVIII DMR vs starch content of needles ( $\%$ dry mass)........87

XXXIX DMR vs starch content of twigs (\% dry mass).........88

XXXX Branch rating vs starch content of needles (\% dry mass). 89

XXXXI Branch rating vs starch content of twigs ( $\%$ dry mass)... 90

XXXXII Infection class vs starch content of needles .........991

XXXXIII Infection class vs starch content of twigs ..........992 


\section{LIST OF FIGURES}

FIGURE

PAGE

1. Example of a local swelling on Pinus contorta

caused by Arceuthobium americanum.............. 3

2. Example of a systemic witch's broom on Pinus

contorta caused by $\underline{A}$. americanum.............. 6

3. Model of the carbon budget of the host $p l a n t \ldots . . . . . .8$

4. Model of the effects of a parasite upon its

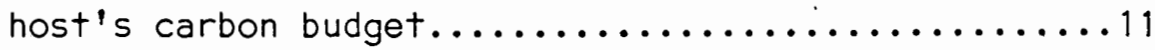

5. Diagram of a systemically infected twig showing

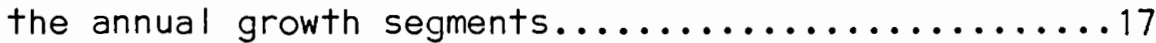

6. The effect of infection upon the mean needle

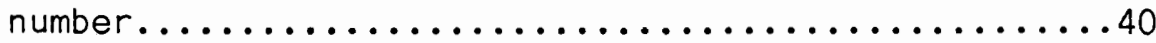

7. The effect of infection upon needle length...........41

8. The effect of infection upon needle biomass.........42

9. The effect of infection upon mass per needle........43

10. The effect of infection upon total needle length.......44

11. The effect of infection upon total needle surface

area

12. The effect of infection upon twig length............46

13. The effect of infection upon twig unit mass..........47

14. The effect of infection upon the starch content

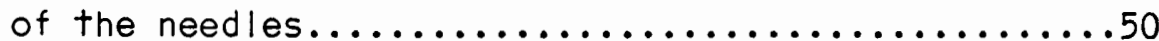


15 The effect of infection upon the starch content

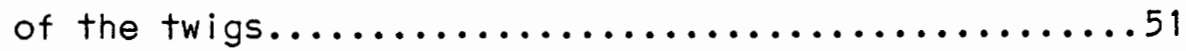


INTRODUCTION

Parasitism is an exceedingly common means of existence. Price (1980) has estimated that over half of the animal species in the world are parasitic during a portion of their life cycles. This figure is much lower. for plants. I estimate that approximately 3000 dicotyledonous species, or 1 to $2 \%$ of all higher plant species, are parasitic. Although the number of species of parasitic plants is low, many of the species are ecologically important because of their common occurrence and wide distribution.

Frequently, ecologists treat parasitism as a type of predatorprey relationship (e.g. Crofton, 1971; Odum, 1971; Ricklefs, 1979; Anderson and May, 1978; Pianka, 1978; and Price, 1980). In both the parasite-host and the predator-prey associations, the interaction is beneficial to one member and detrimental to the other (Odum, 1959). However, I believe there are substantial ecological differences between the two types of associations. The predator's effect is to remove an individual from the prey population. An individual predator uses as its energy resource some part of its prey population over the course of its life span. On the other hand, parasites obtain nourishment from a single host over some period of time, often allowing the host to continue as an active member of its population. Parasites have as their energy resource, one individual host organism which sustains them until parasite reproduction occurs. 
Throughout the time the host survives, its vigor and performance often decline as compared with uninfected individuals of similar age and type. This subtlety of decline may have very different effects on the community's structure and function than does the rapid removal of prey by predation.

Dwarf mistletoes (Arceuthobium) are a specialized group of vascular plant parasites which are parasltic primarily upon members of the family Pinaceae (figure 1). Arceuthobium is a member of the family Viscaceae and is represented in both the old and new worlds (Hawksworth and Wiens, 1972). As currently described, there are six old world species (Hawksworth and Wiens, 1972; 1976) and 32 new world species (Hawksworth and Wiens, 1972; 1977; and 1980). The greatest diversity occurs in northwest Mexico and the western United States and Canada. Seventeen of the new world species occur in the United States, of which, eight are found in Oregon (Hawksworth and Wiens, 1972; Knutson and Tinnin, 1981).

There is a range of host response to infection by Arceuthobium. Some of the host species show little response other than a local swelling of the twig at the site of infection. Other species show extensive modification of growth by the branch supporting the infection (Tinnin, Hawksworth and Knutson, 1982). I have selected for study from among the species readily available, a host-parasite complex which displays the widest range of host response.

When Arceuthobium americanum (Nutt. ex. Engelm.) infects its host (Pinus contorta var. murrayana (Dougl..)), there are two types of infections which may result. The first type is a local swelling 


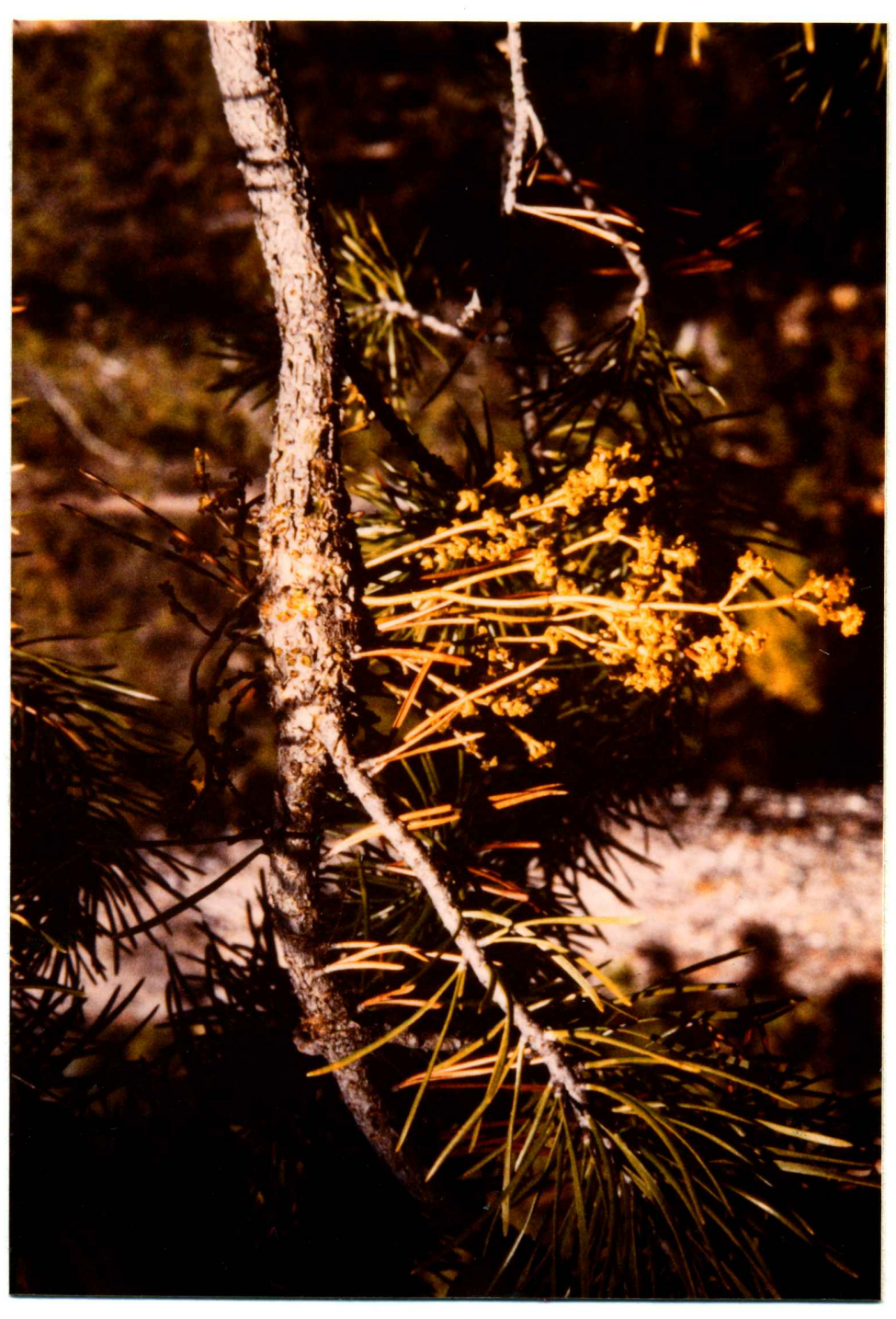

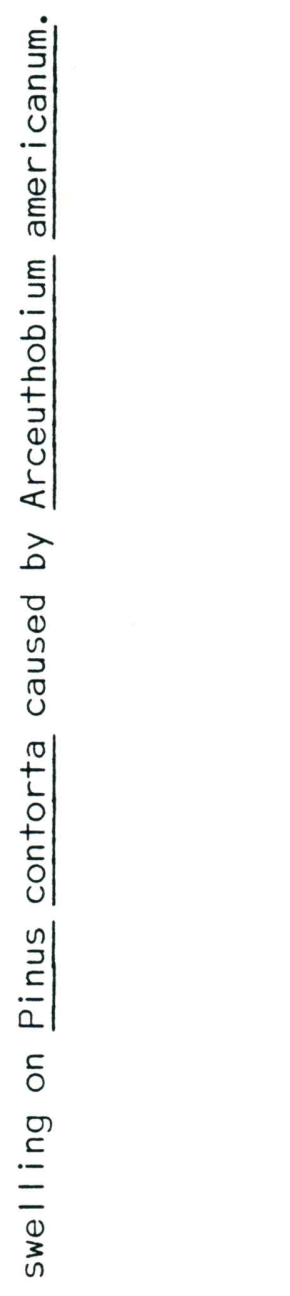

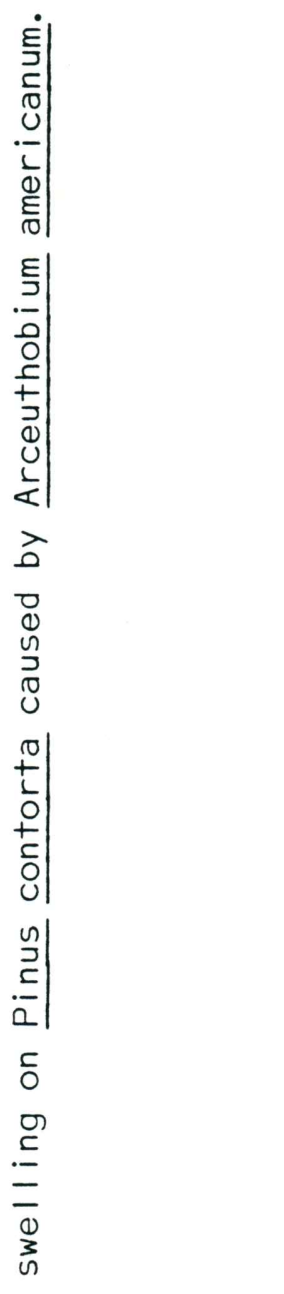

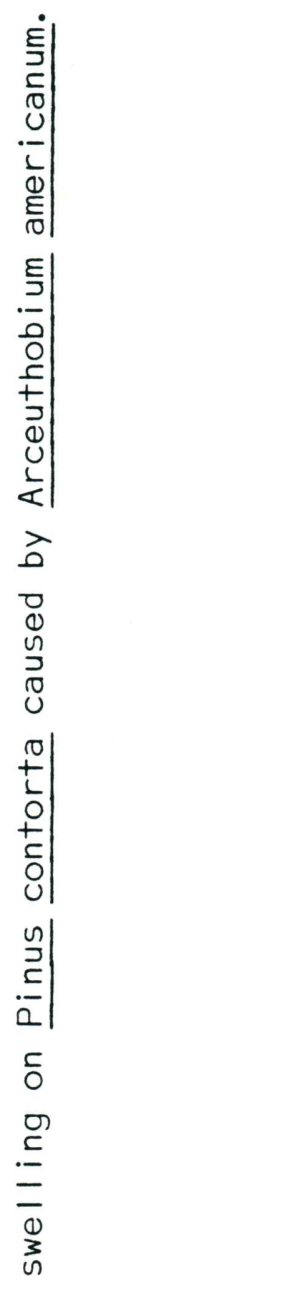

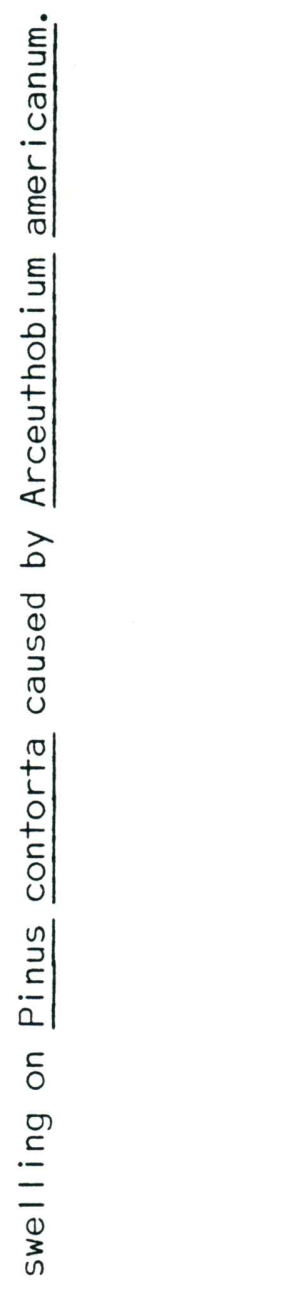

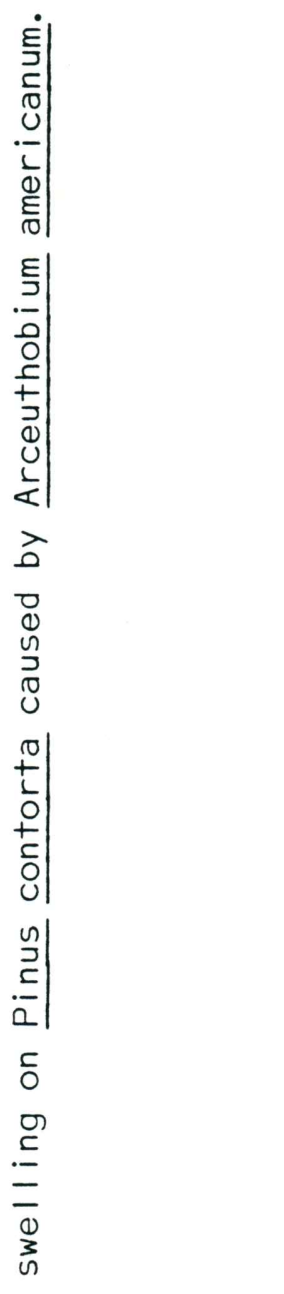

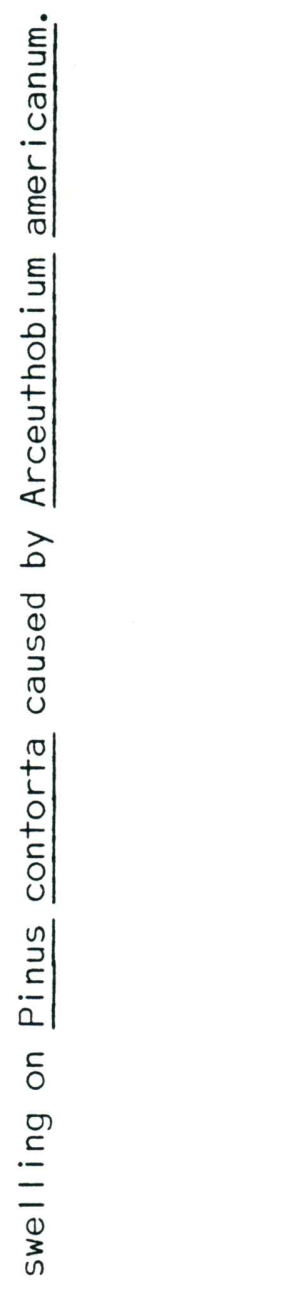

రृ

$\pi$

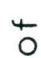

产

安

造 
(figure 1). In this type of infection, the endophytic system (the part of the Arceuthobium plant inside the host) is confined to that portion of the branch where the seed first landed. The host branch at this point becomes swollen, and the aerial shoots are confined to the swelling. The other type of infection is a systemic infection (figure 2). In this type of infection, the endophytic system of the parasite invades host buds and grows along with newly formed twigs. There is a loss of apical dominance which results in a proliferation of lateral shoots (Hawksworth and Wiens, 1972). In Pinus contorta, aerial shoots arise near bud scars on portions of twigs that are 3 to 10 years old. The various species of Arceuthobium are relatively host specific (i.e. they grow predominantly on one host species). Arceuthobium americanum is found predominantly on Pinus contorta (lodgepole pine) and $\underline{P}$. banksiana (jack pine), but it also occurs on $\underline{P}$. ponderosa, $\underline{P}$. aristata, $\underline{P}$ albicaulis, $\underline{P}$. flexilis, and is rarely found on Picea glauca, P. engelmanni i, and P. pungens (Gill and Hawksworth, 1964; Hawksworth and Wiens, 1972). Arceuthobium americanum has the largest range of any of the North American dwarf mistletoes, occurring widely throughout the western United States and Canada (Hawksworth and Wiens, 1972): Throughout its range, $\underline{A}$. americanum is responsible for heavy timber losses (e.g. Hawksworth and Lusher, 1956; Hawksworth, 1958a; Hawksworth and Graham, 1963; Gill and Hawksworth, 1964; Hawksworth and Hinds, 1964; Baranyay, 1970; Baranyay and Safranyik, 1970; Baranyay and Smith, 1972; Hawksworth and Wiens, 1972; Johnson, Hawksworth and Drummond, 1981). Studies have shown that from one-third to greater than one-half of all commercial, merchantable, lodgepole pine trees 
are infected with this parasite (Hawksworth, 1958b; Gill and Hawksworth, 1964; Hawksworth and Hinds, 1964; Baranyay, 1970; Baranyay and Safranyik, 1970; Hawksworth and Wiens, 1972; Johnson, Hawksworth and Drummond, 1981). The amount of damage done is positively correlated with the length of time since infection and negatively correlated with the age of the stand when it became infected (Hawksworth, 1958; Hawksworth and Graham, 1963; Gill and Hawksworth, 1964; Hawksworth and Hinds, 1964). Reductions in growth (both in height and diameter) are reported to be 0.7 percent per year (Hawksworth and HInds, 1964) with total reductions in growth of up to $31 \%$ in older trees (Baranyay and Smith, 1972).

Consequential reductions in volume occur with estimated merchantable volume losses at 270,750 cubic meters in Colorada and Wyoming national forests (Johnson, Hawksworth and Drummond, 1981) or 1.9 percent per year for stands in Colorado (Hawksworth and Hinds, 1964). As the infection becomes locally widespread throughout the canopy, mortality may result (Hawksworth and Lusher, 1956; Hawksworth, 1958; Andrews and Daniels, 1960; Gill and Hawksworth, 1964; Baranyay, 1970; Johnson, Hawksworth and Drummond, 1981). The mortality rate in severely infected stands may increase to as much as 5 times that of healthy stands (Hawksworth, 1958a). Often, the presence of the infection seems to predispose the host tree to a variety of other pathogens (e.g. fungi and insects) which kill the tree (Weir, 1916a; 1916b; Kuijt, 1960; Gill and Hawksworth, 1964; Baranyay and Smith, 1972; Hawksworth and Wiens, 1972). Just in the Colorado and Wyoming national forests, losses in potential income from timber sales due to $\underline{A}$. americanum have been estimated at $\$ 1.5 \mathrm{million}$ per year (Johnson, 


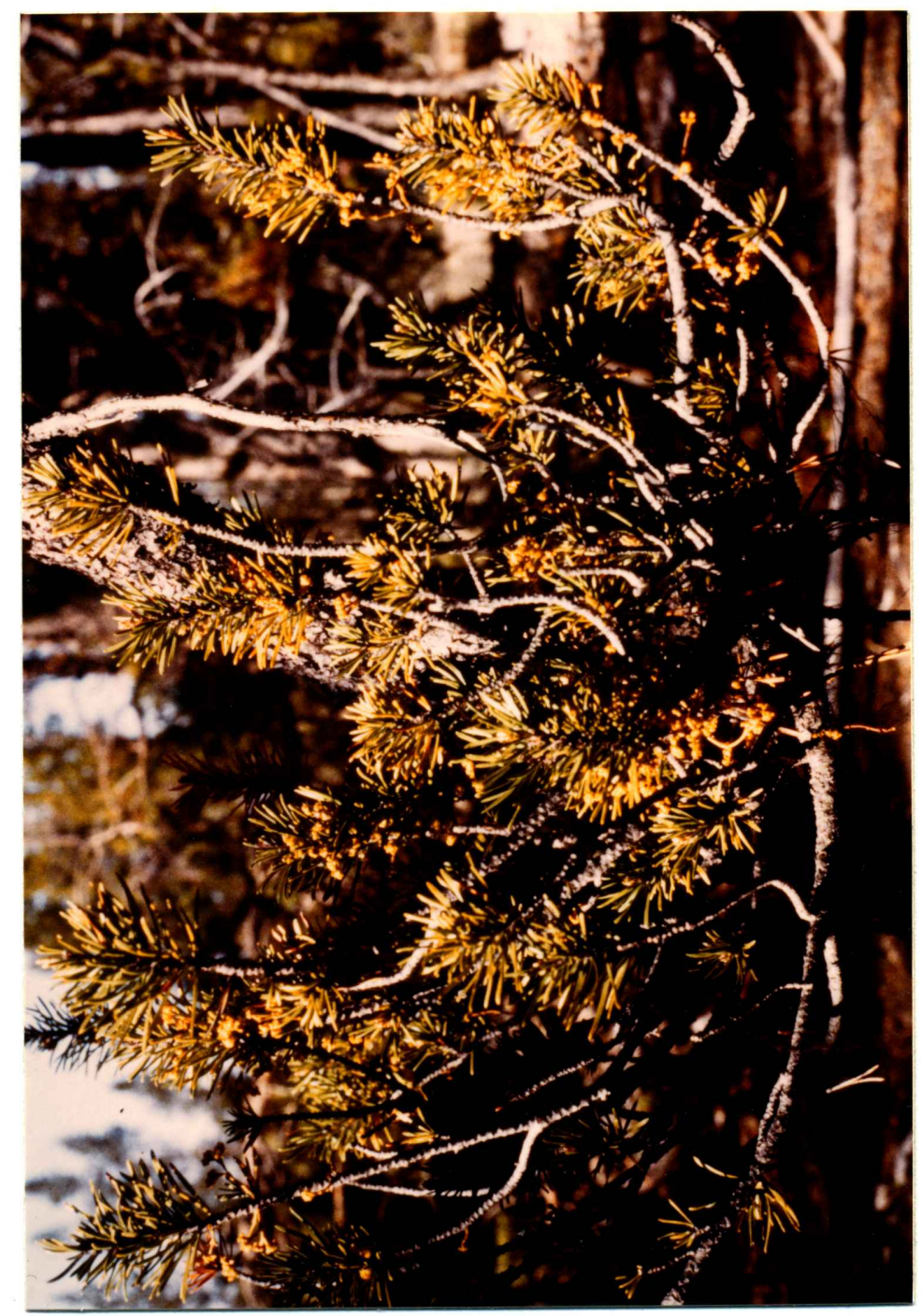

\begin{tabular}{c}
$\dot{E}$ \\
\multicolumn{2}{c}{} \\
$\frac{1}{0}$ \\
$\frac{0}{1}$ \\
\hdashline$\frac{1}{0}$ \\
$\frac{E}{0}$
\end{tabular}

¿i

วิ

D

茎

0
+

0
+
등
0

$n$
2
$\frac{n}{0}$

ㄷํㅇ

름

ᄃ

$+\frac{+}{3}$

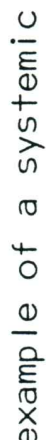

定

$\dot{\sim}$

$\frac{1}{\frac{1}{3}}$ 
Hawksworth and Drummond, 1981).

The manner in which dwarf mistletoe reduces host growth is not known. It has been demonstrated that it is a strong sink on its host for water (Baranyay and Safranyik, 1970; Clark and Bonga, 1970; Mark and Reid, 1971; Fisher, 1975), minerals (McDowell, 1964), and carbon (Rediske and Shea, 1961; McDowell; 1964; Hull and Leonard, 1964a; 1964b; Leonard and Hull, 1965; Smith, et al, 1969; and Clark and Bonga, 1970). It has also been demonstrated to have the ability to alter its host's normal hormonal levels (Paquet, 1979). To what extent any or all of these factors play a role has yet to be determined. The goal of my research is to study the cause of decline among the hosts of $\underline{A}$. americanum.

The carbon budget of the host

As the host plant photosynthesizes (figure 3), it fixes carbon, which is then utilized by the plant. Some of this carbon is irreversibly lost from the system through respiration, herbivory, or breakage. Some of the carbon is converted into structural components (i.e. cellulose) or secondary compounds (i.e. resin). Some of the carbon is converted into metabolic compounds (i.e. enzymes) and storage products (i.e. starch). While both of the latter components may be used by the plant, it is the storage component which is mobilized in times of carbon shortage. The addition of the parasite to the model adds a new dimension. It is not enough to know that the parasite is a carbon "sink". It is also important to know where and how the parasite alters its host's carbon budget.

The aerial shoots of Arceuthobium contain chlorophylls a and b 


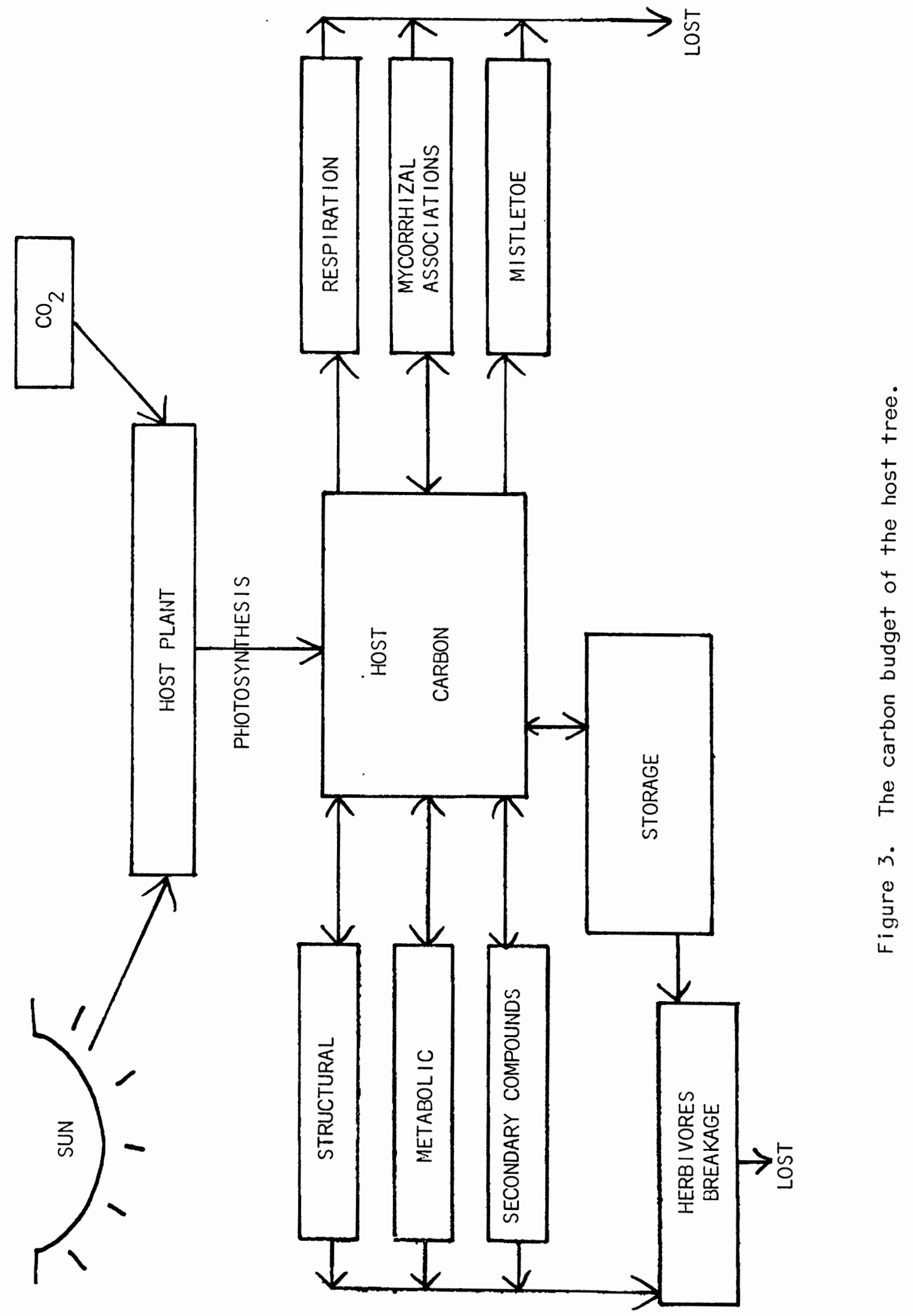


(Hull and Leonard, 1964b), and are capable of photosynthesis. Miller and Tocher (1975) have shown that the aerial shoots of Arceuthobium tsugense are capable of supplying approximately 25 percent of their respiratory needs. The remainder must be made up by the host plant. Rediske and Shea (1961) demonstrated that translocation of photosynthate from the host to the parasite did occur. They also found a small amount of reverse flow (i.e. from the dwarf mistletoe, back to the host). They concluded that the mistletoe acts as a physical "girdle" to the host, preventing the boleward translocation of distally produced photosynthate beyond the point of infection. When Hull and Leonard (1964a; 1964b; and Leonard and Hull, 1965) repeated the experiments, they too came to the conclusion that the host supplies large quantities of photosynthate to the mistletoe, but they found no reverse flow, attributing Rediske and Shea's results to "leakage" in the experimental setup. Not only did Hull and Leonard find no translocation from the mistletoe back to the host, but they also found that there was no translocation from the aerial shoots back to the endophytic system of the dwarf mistletoe. They found no evidence of a physical barrier to translocation in the host, but that at certain times of the year, the mistletoe acted as such a strong sink, that little photosynthate remained available beyond the point of infection. Leonard and Hull also found that the presence of dwarf mistletoe could stimulate translocation from the main bole into defoliated, infected, lateral branches.

Since dwarf mistletoe is such a strong carbon sink, it seems reasonable to expect that any effect should be reflected in the most 
mutable component of its host's carbon budget, storage. One of the primary storage products in pine is starch (Kozlowski and Keller, 1966; Kramer and Kozlowski, 1979; Webb, 1981). The effect that parasites have upon the starch content of their hosts has been examined for a variety of parasites (Allen, 1942; Inman, 1962; Singh, et al, 1968; Wardlaw, 1968; Smith, et al, 1969; Misra, 1970; MacDonald and Strobel, 1970; Daly, 1976; and DeLe Harpe, et al, 1981). Any type of parasitic infection generally leads to an increase in the starch concentration of the infected host tissues (Allen, 1942; Inman, 1962; MacDonald and Strobel, 1970; Daly, 1976). However, investigators working with parasitic vascular plants have found contradictory results. Singh, et a) (1968), while finding an accumulation of starch in the tissues of Orobanche and Cuscuta, found that the infected host tissues generally contained less starch than uninfected controls. Misra (1970) found higher concentrations of starch in the host tissues that were infected with Dendrophthoe falcata. Munteanu and Kalo (1971) found higher concentrations of carbohydrates in host tissues infected with Viscum album. In Arceuthobium, Weir (1918) concluded that infected branches from witch's brooms contained higher amounts of starch than did uninfected branches. Hull and Leonard (1964a) found the opposite.

\section{The proposed research}

The specific aim of my study was to investigate the effect that Arceuthobium americanum has upon a part of the carbon budget of its host, Pinus contorta (lodgepole pine). As shown in figure 4 , the host plant may be expected to have priorities for carbon allocation (Kramer and Kozlowski, 1979; Waring, et al, 1980). Assimilated carbon that 


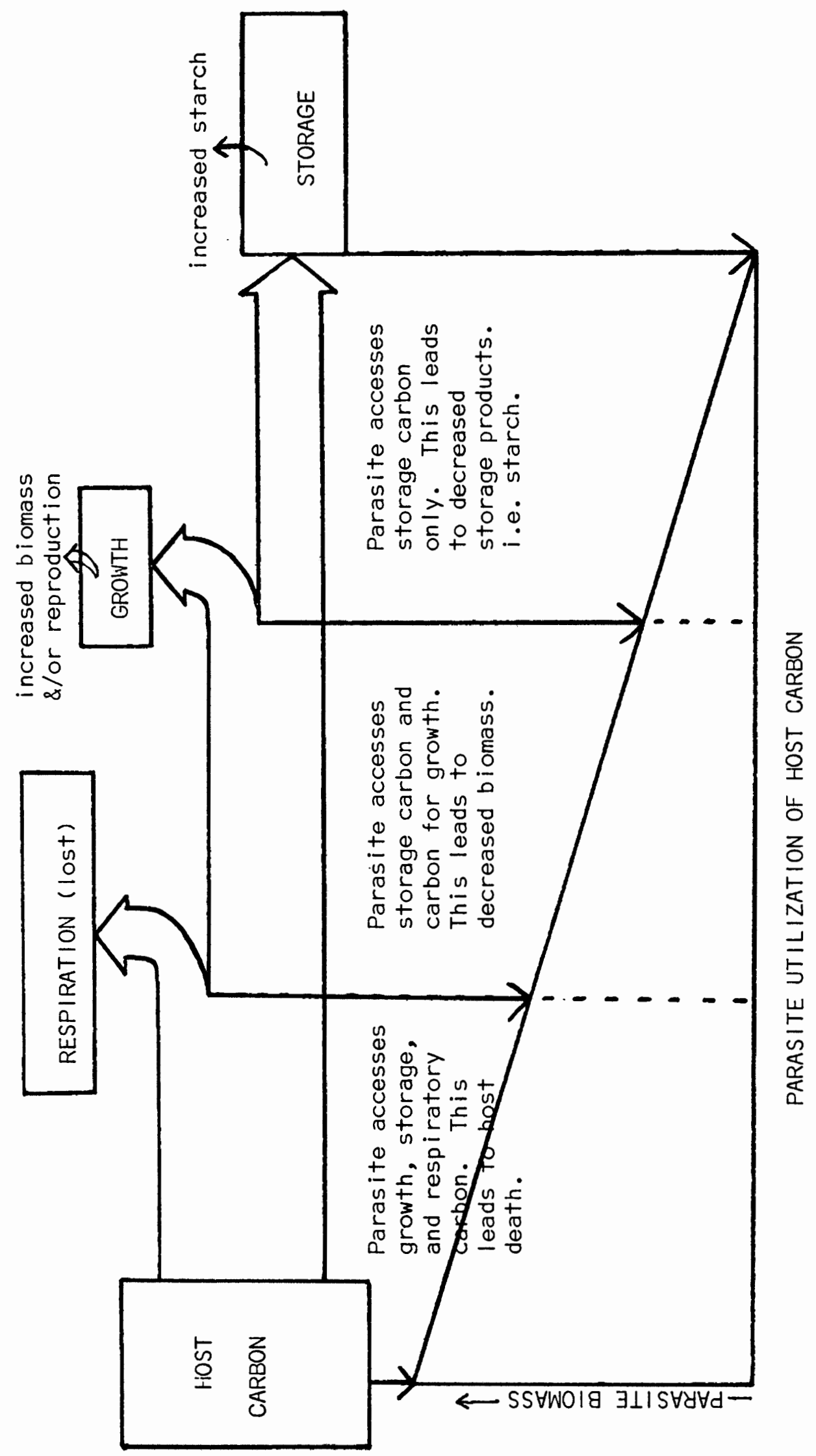


is in excess of the amount necessary to maintain metabolic functions can go for increases in structural biomass and finally for storage. The proposed model suggests that the parasite will initially access the host's carbon budget by way of its most available component, starch. Subsequent carbon removal would affect that allocated for growth, and finally, that allocated for respiration. If the model is accurate, the presence of the mistletoe should be reflected first, in a decreased amount of starch, then by decreased growth (i.e. biomass allocation), and finally, by decreased metabolic processes followed shortly thereafter by the death of the host tree. These effects will be directly related to the biomass of the parasite, although the amount of the parasite necessary to produce the effects is not known. The shape and slope of the function are also unknown.

My research investigated the storage and biomass allocation of the host and how it was altered with the addition of the parasite. Although the manner in which parasites alter the starch concentrations of their hosts has been reported (Weir, 1918; Hull and Leonard, 1964a; Singh, et al, 1968; Misra, 1970; Munteanu and Kalo, 1971; Daly, 1976), the results have been contradictory. Many workers have demonstrated decreases in both height and diameter growth in infected plants (Weir, 1916a; 1916b; 11918; Kuijt, 1960; Gill and Hawksworth, 1964; Hawksworth and HInds 1964; Baranyay and Safranyik, 1970; Baranyay and Smith, 1972). There have also been indications of reductions in growth (both in needles and stems) of infected branches (Weir, 1916a; 1918; Kuijt, 1960). Recent work on Douglas fir (Tinnin and Knutson, 1980) has demonstrated branch and twig alterations caused by dwarf mistletoe such as reductions in twig mass per unit length, individual needle 
mass, and increases in twig length.

I have tested the accuracy of my model by looking at concentrations of starch in uninfected and variously infected host tissues (both needles and twigs), and by measuring the following physical features of needles and twigs: needle number, needle length, needle biomass, total needle biomass, mass per needle, total needle surface area, twig length, twig biomass, and twig unit mass. 


\section{MATERIALS AND METHODS}

Sites

Plant material was collected from two sites. Site 1 was located 13 miles south of Sisters, Oregon, on US Forest Service road 1534. This site was located at an elevation of approximately $2000 \mathrm{~m}$. Site 2 was located on US Forest Service road 243-1, 1 mile off of highway 58. This intersection was 1.7 miles east of the Crescent Lake junction. This site was at an approximate elevation of $1750 \mathrm{~m}$. Both sites were predominantly single species stands of Pinus contorta having mature trees of similar age, and growing on nearly level terrain.

At each site, the study area was divided into a $3 \times 3$ grid of one hectare squares. Three plots were than randomly selected from each grid. On each plot, all major canopy trees were numbered and rated according to the "6-point" dwarf mistletoe rating (DMR) system (Hawksworth and Lusher, 1956). 'The trees were also placed in subcategories according to whether the majority of infections present were of the local or the systemic type. Three trees from each subcategory in each available DMR class were then randomly selected.

1. In this system, the tree canopy is divided into three sections and each section is rated as: 0 , uninfected; 1 , lightly infected; or 3 , heavily infected. The sum total of the values from the three sections is the DMR for that tree. A tree can thus be placed in categories ranging from 0 to 6 , with 6 being a very heavily infected tree. 
Other measurements were taken at the sites. At the time of twig collection, each tree was cored to determine its age, and height and DBH (diameter at breast height) were measured. At a later date, corings were again made to determine a 5 year radial growth increment. Also noted was bark thickness, overall needle color, needle longevity, and density.

Measurements of twig samples

Samples for chemical analysis were taken from branches that were located on the southwest sides of the trees. An attempt was made to collect all the samples from the same height on the trees (except in the case of the Sister's May 14, 1981 sample). As each sample was removed, the infection level was noted according to the following "branch rating" system (BRS): 0, uninfected branch from an uninfected tree; 1, uninfected branch from a infected tree; 2 , one local swelling with no broom; 3, more than one local swelling with no broom; 4, nonsystemic broom; 5, systemic broom; and 6, systemic broom with at least one local swelling. At the Crescent Lake site, samples were collected on June 22, 1980; November 15, 1980; and January 13, 1981. At the Sister's site, samples were collected on January 11,1981 and May 14, 1981. The May 14th sample was collected in a different manner than the normal. An attempt was made to collect uninfected, local and systemic samples from each tree sampled. In doing so, samples were collected from several heights and compass orientations on each host tree.

All samples were labeled and placed in plastic bags which were 
quickly placed on dry ice, transported back to the lab and placed in a freezer at $-40^{\circ} \mathrm{C}$.

Samples were removed from the freezer one at a time. Measurements of twig length, number of needles, and length of needles were made for the annual growth segments of 1978, 1979 and 1980 (figure 5). For the 1978 and 1980 categories, the needles and stems were separated and measured, and the fresh masses were determined to the nearest $0.1 \mathrm{mg}$. The samples were then placed in a drying oven at $80^{\circ} \mathrm{C}$. for 48 hours and reweighed to determine dry mass. The 1979 growth increment was treated differently. As the needles were counted, one of each pair was set aside for further treatment. They were placed back in the freezer until they could be weighed and further prepared for chemical analysis. The other half of each fascicle was treated as a regular twig sample to obtain fresh and dry masses.

\section{Preparation of starch samples}

To determine the amount of starch in the tissue, the needles were ground in $10-20 \mathrm{ml}$ of $0.5 \mathrm{~N} \mathrm{NaOH}$ in a Sorvall Omni mixer at medium speed. Grinding time continued for five minutes after the last recognizable needle or stem segment was observed. The slurry was allowed to stand for 30 minutes, after which time it was neutralized with $0.5 \mathrm{~N}$ acetic acid.

To remove photometrically interfering compounds (i.e. pigments and phenolics) from the samples, enough Methanol:Chloroform:Water was added to the ground samples to bring the volumes to the desired ratio ( $M: C: W, 12: 5: 3$ by volume). The samples were centrifuged, and the supernatant was removed and saved. The remaining residue was 

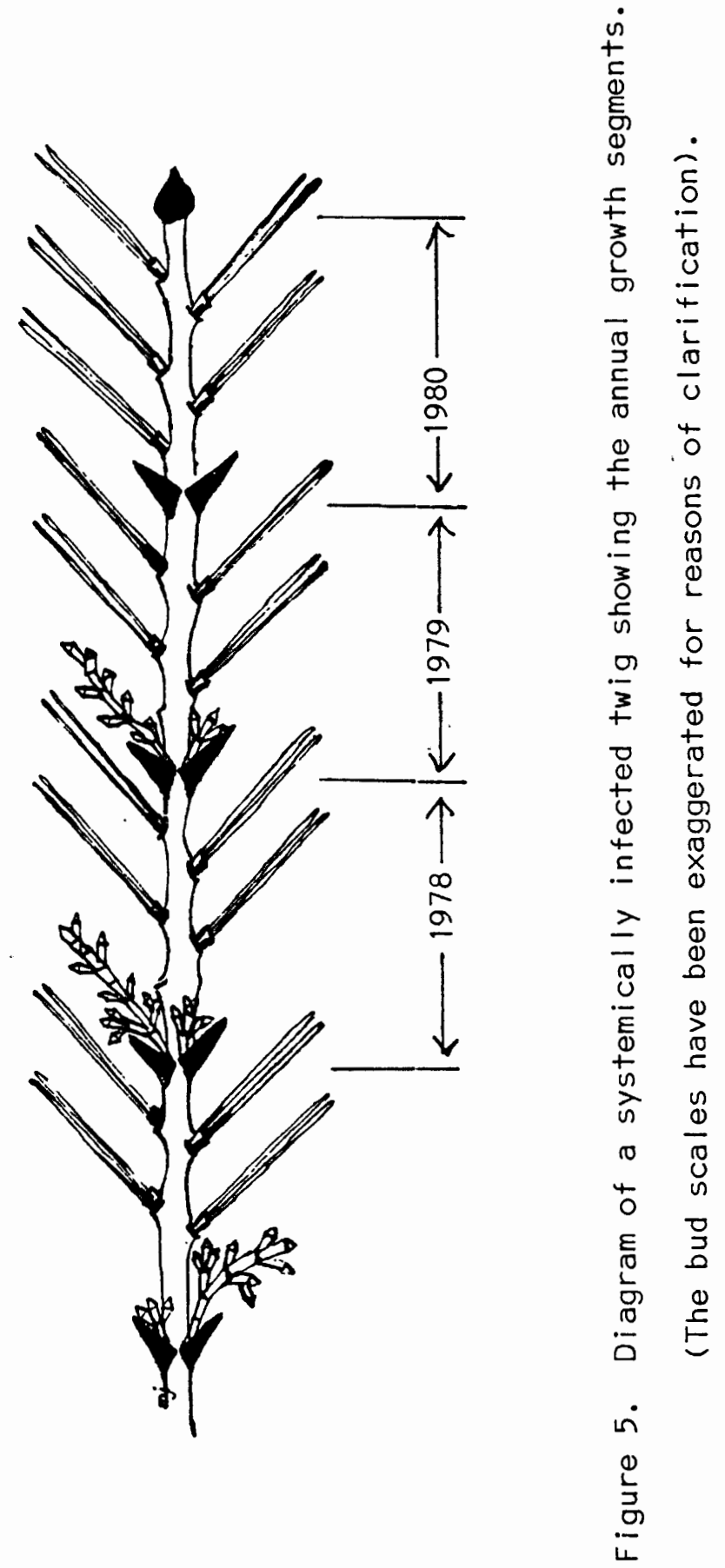
reextracted in a similar manner by adding $M: C: W, 12: 5: 3$, two to four times, until all pigments were removed and the resulting supernatant was clear. Polar compounds were separated from the pigments and lipids by adding $3 \mathrm{ml}$ of glass distilled water per $5 \mathrm{ml} \mathrm{M:C:W.} \mathrm{Samples} \mathrm{were}$ mixed and allowed to stand several hours or overnight until the mixture separated. The pigmented lower layer (the chloroform layer) was removed and discarded and the upper, water-soluble layer was saved. The interface area between the two layers was centrifuged to ensure complete separation. The samples were placed in a $50^{\circ} \mathrm{C}$. water bath overnight, under the hood, to drive off any remaining chloroform. One $\mathrm{ml}$ of $50 \%$ ethanol was added to the samples, which were then placed in a boiling water bath for 30 minutes to gelatinize the starch. After cooling, the samples were measured to the nearest $\mathrm{ml}$, placed in glass bottles, and stored in the freezer (Haissig and Dickson, 1979).

\section{Standard solutions}

Starch: Approximately $4.5 \mathrm{mg}$ of dried soluble starch was weighed accurately to the nearest $0.1 \mathrm{mg}$ and dissolved in $2.5 \mathrm{ml}$ of $0.5 \mathrm{~N} \mathrm{NaOH}$. This was stirred until all the starch was in solution, then diluted with distilled water to $20 \mathrm{ml}$. Acetic acid $(0.5 \mathrm{~N} ; 2.5$ $\mathrm{ml}$ ) was added and the solution diluted to a final volume of $45 \mathrm{ml}$. This solution served as a measured amount of starch used to calibrate the efficiency of the enzymes.

Enzymes: $10 \mathrm{mg}$ of amyloglucosidase from Rhizopus (Sigma) was dissolved in $10 \mathrm{ml}$ of sodium acetate buffer $(0.1 \mathrm{M}$; $\mathrm{pH}=4.8)$. This solution was centrifuged before use (Dekker and Richard, 1971). In addition to amyloglucosidase, alpha amylase was added to ensure the 
complete breakage of all starch chains (Webb and Karchesy, 1977). Alpha amylase (type X-A; from Aspergillus oryzae) $(0.5 \mathrm{~g}$ ) was added to $30 \mathrm{ml}$ of buffer $(0.02 \mathrm{M}$ sodium phosphate buffer; $\mathrm{pH}=6.9)$. This solution $(0.5 \mathrm{ml})$ was added to $30 \mathrm{ml}$ of the amyloglucosidase solution to give 10 units of amylase activity per $\mathrm{ml}$ of solution (Webb, pers. comm. ).

A glucose oxidase solution was made by dissolving $30 \mathrm{mg}$ of glucose oxidase (Sigma, type 11, from Aspergillus niger), $10 \mathrm{mg}$ of o-dianisidine hydrochloride (Sigma), and $3 \mathrm{mg}$ of peroxidase (Sigma, from "horseradish") in $100 \mathrm{ml}$ of tris-glycerol buffer $(0.5 \mathrm{M} ; \mathrm{pH}=7.0)$ (Dekker and Richards, 1971). This solution was stored at $4^{\circ} \mathrm{C}$. in a brown glass bottle.

Chemical analysis of samples

Samples were divided into two aliquots; half were run with amylase to determine the total glucose content and half were run without amylase to determine the free glucose content. The amount of starch in the plant tissue was determined by the difference between free and total glucose.

To determine total glucose, $0.5 \mathrm{ml}$ of the sample was mixed with $0.5 \mathrm{ml}$ amyloglucosidase and alpha amylase solution, and placed in a $30^{\circ} \mathrm{C}$. incubator for one hour. Two $\mathrm{ml}$ of glucose oxidase solution was then added, the solution was mixed and again placed in a $30^{\circ} \mathrm{C}$. incubator for one hour. Four $\mathrm{ml}$ of $5 \mathrm{~N} \mathrm{HCl}$ were added and the absorbance read in a Perkin-Elmer (model 124D) dual beam spectrophotometer at 540 $\mathrm{nm}$.

To determine free glucose, one $\mathrm{ml}$ of sample was mixed with two $\mathrm{ml}$ 
of glucose oxidase solution, and placed in a $30^{\circ} \mathrm{C}$. incubator for one hour. Four $\mathrm{ml}$ of $\mathrm{HCl}$ were added, and the absorbance read.

A standard curve was run with each batch of samples. The standard curve consisted of known amounts of glucose from 0 to $54 \mu \mathrm{g}$ glucose/ml sodium acetate buffer.

Since fresh mass only was available for the ground samples, dry mass had to be estimated in order that the starch content could be expressed as $\mu \mathrm{g}$ starch per gram dry mass. Dry needle mass was estimated from the fascicle halves that were dried and weighed. The dry mass of the stems was estimated as the average of that from the years before and after the sample.

\section{$\underline{\text { Statistical analysis }}$}

Statistical analyses were run on all the data. All data were compared to the dwarf mistletoe rating system (DMR), the branch rating system (BRS), and the infection class of the branch by means of a OneWay ANOVA and a linear regression with more than one value of $y$ for each value of $x$. All the values were also subjected to a studentNewman-Keuls test (Sokal and Rohlf, 1969; computer program by Withers). 


\section{RESULTS}

Tables 1 and 11 show the mean DBH (diameter at breast height), height, age, annual radial increment, and 5 year radial growth increment for each DMR at each site. There was not an entire DMR range at either site. At the Crescent Lake site, the DMR ranged from 0 to 5, and at the Sisters site, the DMR ranged from 3 to 6 . Thus, the entire DMr range could be examined only by reference to both sites. Because of the methods used to select sample trees, the data in Tables 1 and 11 are not characteristic for the stand as the whole, but are only representative of the trees slected for study.

A compilation of all data collected has been placed in the appendix. Not all trees were studied during each sampling date. The June 22 and the November 15 samples from the Crescent Lake site are incomplete due to mechanical failure. The Crescent Lake January 13 and the Sisters January 11 samples were randomly selected subsamples of the trees. Since different numbers of samples were taken from the trees, the number of samples in each DMR category varies. It is these two dates which will be extensively discussed in the text as they were most thoroughly sampled and all chemical procedures were well established.

As the Crescent Lake site was without systemic infections, several trees with systemic brooms were non-randomly selected from just outside the site. 
$z \nabla \sigma \sigma \infty \omega \infty$

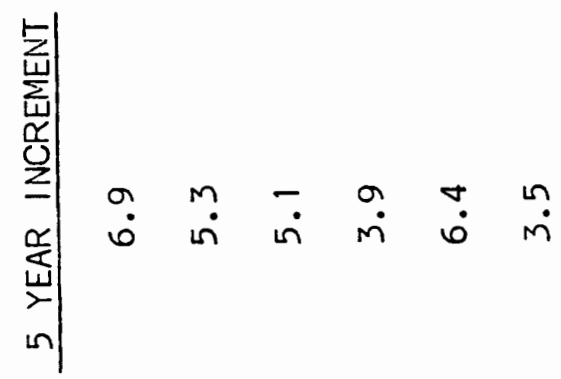

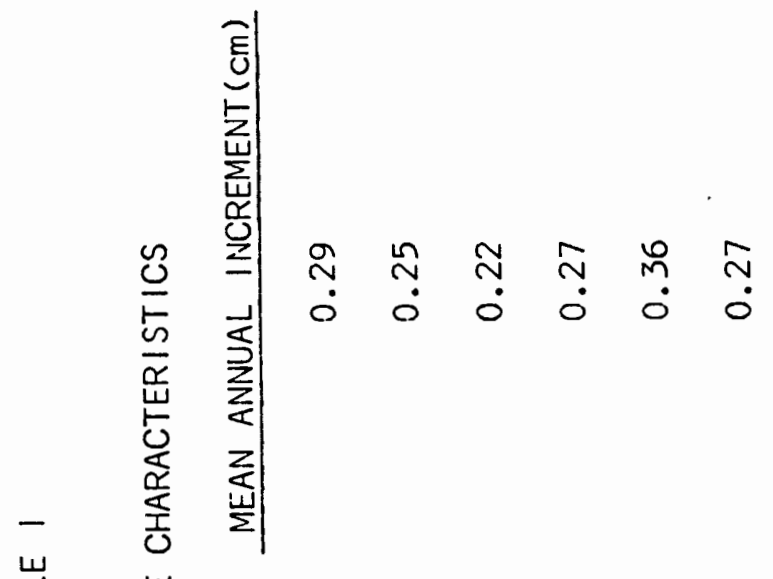

岩崖店

岁

岕

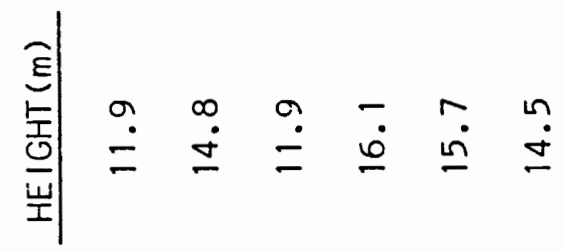

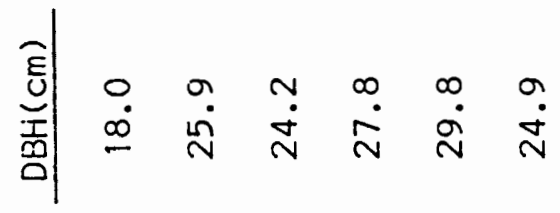

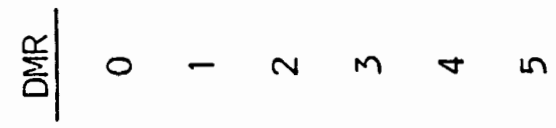


$z \mid=0$ 의

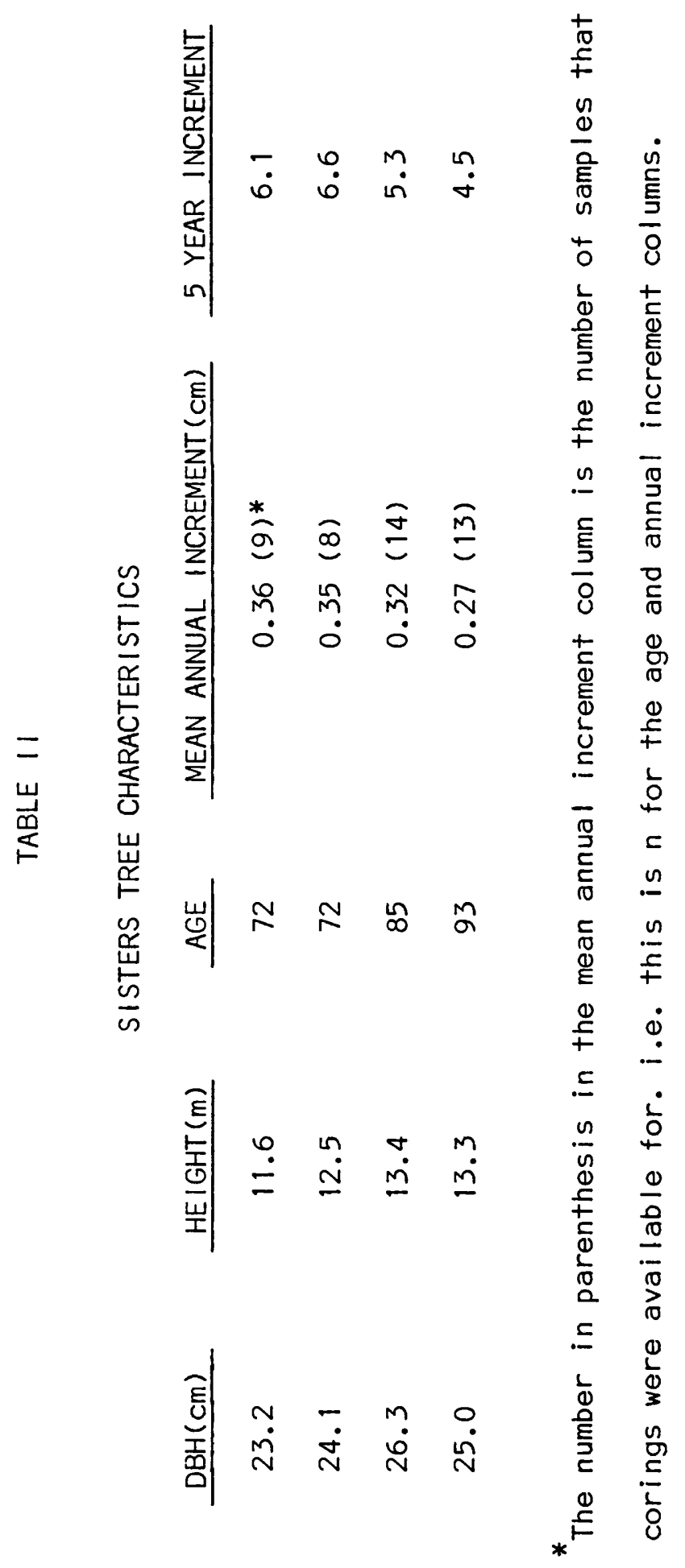

$\frac{\alpha}{D} \mid m \quad \sigma \quad$ in 
Physical features vs DMR

Needle biomass (Table 111 ) showed significant decreases as the dwarf mistletoe rating (DMR) increased. Results from the StudentNewman-Keuls (SNK) test showed this to be due to significant differences between uninfected and moderately to heavily infected trees. Mean needle number (Table 111 ) exhibited a tendency to decrease as the DMR increased, but no significant difference was found. Mean needle length and mean mass per needle (Table 111 ) were not significant with regard to DMR.

Length of twig segments (Table IV) did exhibit a significant relationship with DMR. Mean twig length tended to decrease, except with a DMR of 6 , where an increase was found. SNK showed differences between uninfected and moderately infected trees, and moderately infected trees and trees with a DMR of 6 . Twig biomass (Table IV) showed some tendencies for reduction in means with increasing DMR, but the relationship was, for the most part, insignificant. Twig unit mass (Table IV) showed no significant relationship with DMR.

Also examined was overall needle color, needle longevity, and needle density, bark thickness, and five year radial growth increment. Of these, only the radial growth increment (Table 1, 11) was found to be statistically significant ( $p<0.01$ for both sites), with means decreasing as the DMR increased.

Overall, DMR seemed to bear little relationship to any of the physical features of the tree. Needle mass, twig length, and radial growth increment were the only characteristics that were found to be significantly related to DMR, with needle biomass and radial growth 


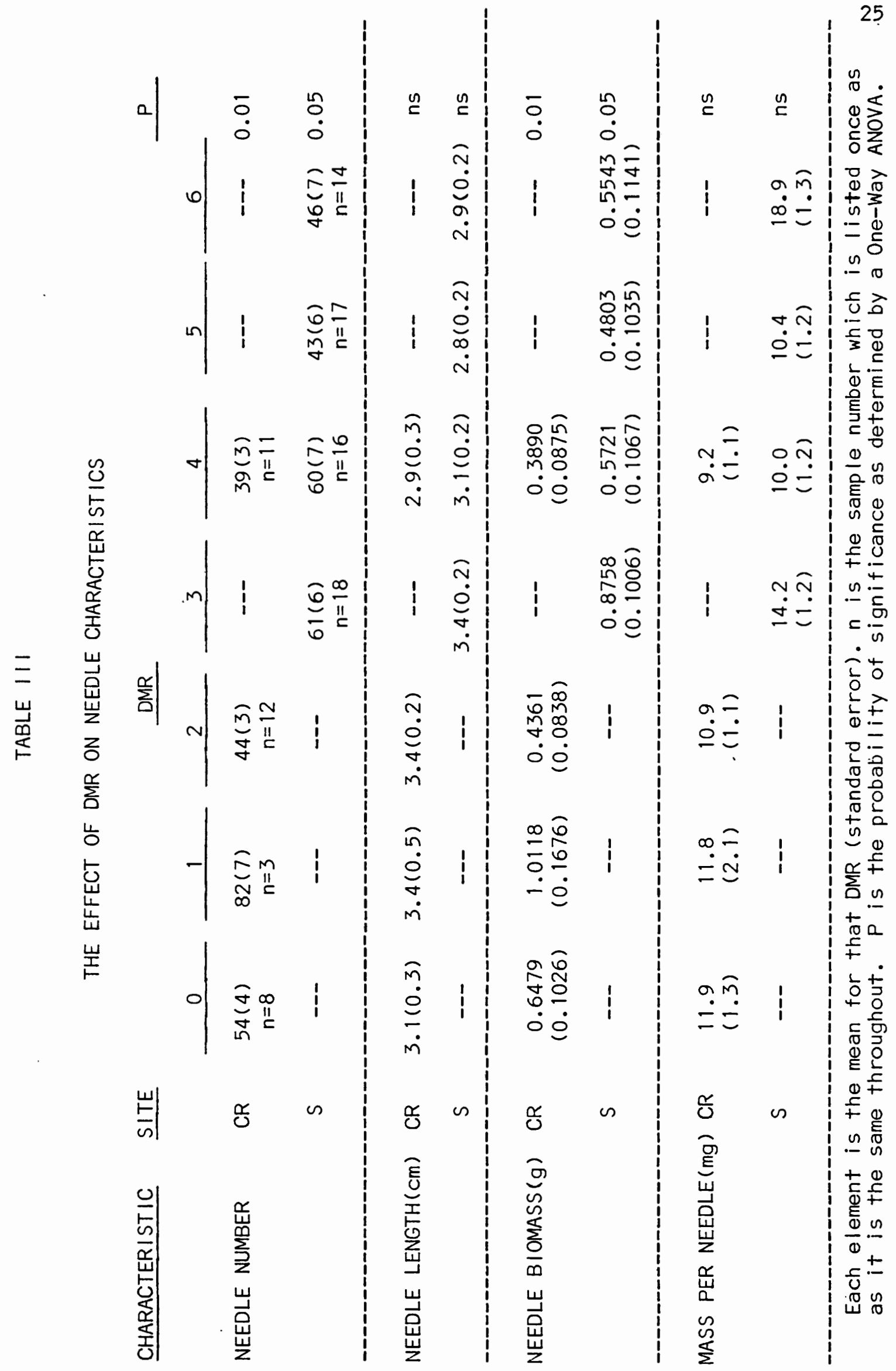




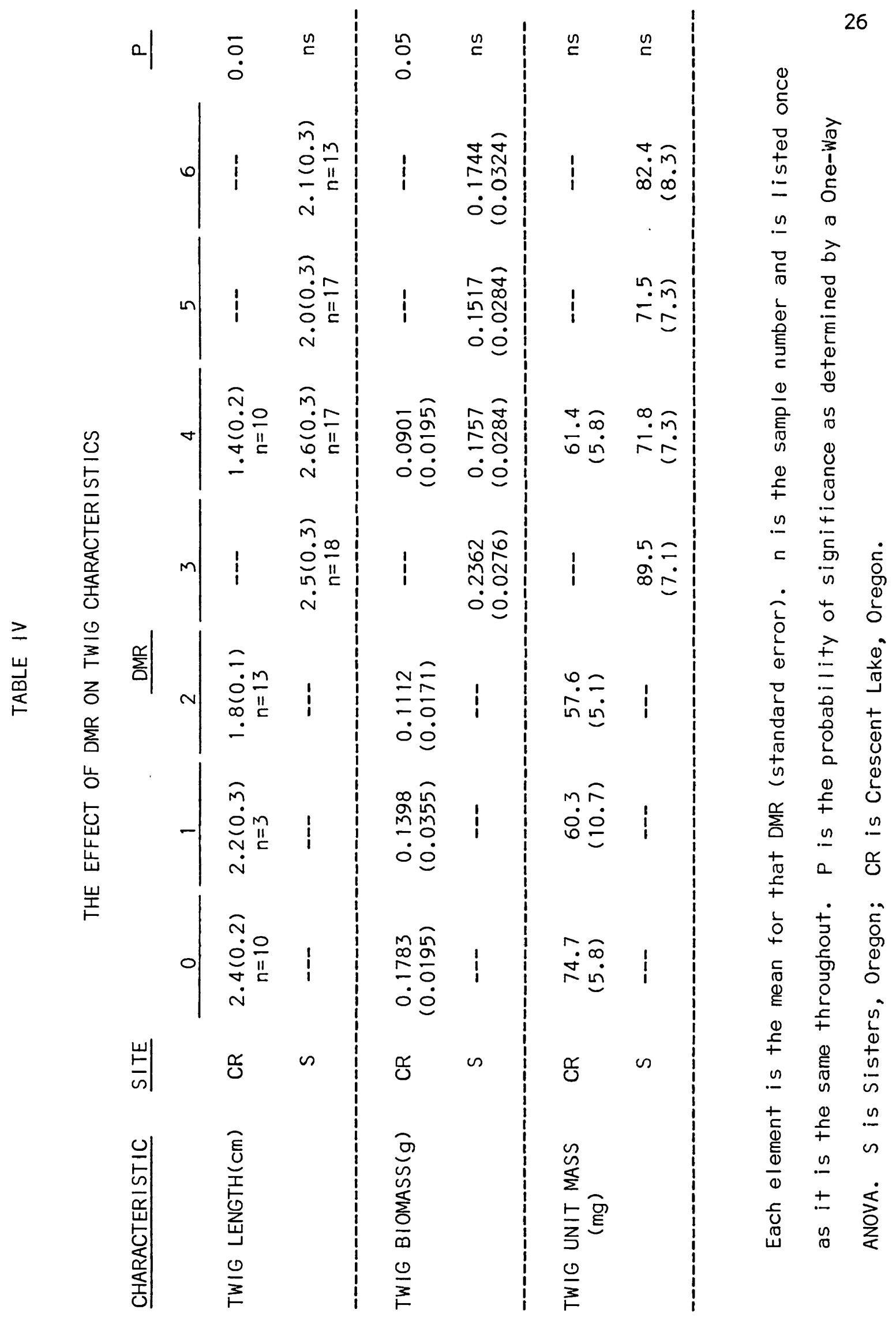


decreasing as DMR increases, and twig length at first decreasing, and then increasing in trees with increasing DMR.

\section{Physical features vs BRS (Infection class)}

In an attempt to evaluate the mistletoe's localized effects on its host, the branch rating system (BRS) was devised. This method, rather than comparing the various growth characteristics to the infection level of the tree, instead compared the characteristics to the infection status of the branch from which they were collected. One interesting feature to emerge from this comparison, was the fact that the type of infection present seemed to have a greater impact on the host than the number of individual infections (i.e. one local infection had the same effect as did many). The branch rating system was, therefore, simplified to the infection class system and the same data was again analyzed. In this system, the samples were classified according to the infection status of the branch that they were taken from. There are three infection classes: 1) an uninfected branch; 2) a locally infected branch; and 3) a systemically infected branch.

Mean needle number (Tables $V, V I I)$ showed significant decreases as the branch rating increased. The number of needles was significantly less on locally infected branches. No apparent differences were found between systemic and nonsystemic branches. This result was observed at both sites.

Mean needle length (Tables $V, V I I$ ) was significantly reduced at both sites as the branch rating increased. The differences were less definate between local and healthy branches, but needles from systemically infected branches were significantly shorter than from either 
TABLE $V$

THE EFFECT OF BRANCH RATING ON NEEDLE CHARACTERISTICS

\begin{tabular}{|c|c|c|c|c|c|c|c|c|c|}
\hline CHARACTERISTIC & SITE & & & BRANCH RAT & & & & & $P$ \\
\hline & & 0 & 1 & 2 & 3 & 4 & 5 & 6 & \\
\hline NEEDLE NUMBER & CR & $\begin{array}{l}54(5) \\
n=8\end{array}$ & $\begin{array}{l}65(6) \\
n=5\end{array}$ & $\begin{array}{l}43(3) \\
n=17\end{array}$ & $\begin{array}{l}30(10) \\
n=2\end{array}$ & $\begin{array}{l}40(10) \\
n=2\end{array}$ & -- & --- & 0.05 \\
\hline & 5 & $\rightarrow$ & $\begin{array}{l}85(13) \\
n=4\end{array}$ & $\begin{array}{l}36(5) \\
n=23\end{array}$ & $\begin{array}{l}49(7) \\
n=16\end{array}$ & $\begin{array}{l}43(18) \\
n=2\end{array}$ & $\begin{array}{l}49(6) \\
n=18\end{array}$ & $\begin{array}{l}28(18) \\
n=2\end{array}$ & ns \\
\hline NEEDLE LENGTH $(\mathrm{cm})$ & CR & $\begin{array}{l}3.1 \\
(0.2)\end{array}$ & $\begin{array}{l}4.3 \\
(0.3)\end{array}$ & $\begin{array}{l}3.0 \\
(0.2)\end{array}$ & $\begin{array}{c}2.2 \\
(0.5)\end{array}$ & $\begin{array}{l}3.4 \\
(0.5)\end{array}$ & -- & $-\infty$ & 0.01 \\
\hline & S & -- & $\begin{array}{l}4.1 \\
(0.3)\end{array}$ & $\begin{array}{l}3.5 \\
(0.1)\end{array}$ & $\begin{array}{l}3.3 \\
(0.2)\end{array}$ & $\begin{array}{c}4.2 \\
(0.4)\end{array}$ & $\begin{array}{c}2.0 \\
(0.1)\end{array}$ & $\begin{array}{c}2.7 \\
(0.4)\end{array}$ & 0.001 \\
\hline $\operatorname{NEEDLE~BIOMASS}(g)$ & CR & $\begin{array}{c}0.6479 \\
(0.1026)\end{array}$ & $\begin{array}{l}0.8705 \\
(0.1297)\end{array}$ & $\begin{array}{c}0.3959 \\
(0.0704)\end{array}$ & $\begin{array}{l}0.1964 \\
(0.2051)\end{array}$ & $\begin{array}{c}0.5359 \\
(0.2051)\end{array}$ & -- & -- & 0.05 \\
\hline & S & -- & $\begin{array}{c}1.5884 \\
(0.1708)\end{array}$ & $\begin{array}{c}0.7304 \\
(0.0712)\end{array}$ & $\begin{array}{l}0.6250 \\
(0.0854)\end{array}$ & $\begin{array}{c}0.6222 \\
(0.2416)\end{array}$ & $\begin{array}{c}0.3344 \\
(0.0805)\end{array}$ & $\begin{array}{c}0.2142 \\
(0.2416)\end{array}$ & 0.001 \\
\hline $\begin{array}{c}\text { MASS PER NEEDLE } \\
\text { (mg) }\end{array}$ & CR & $\begin{array}{r}11.9 \\
(1.0)\end{array}$ & $\begin{array}{r}15.1 \\
(1.2)\end{array}$ & $\begin{array}{c}8.9 \\
(0.7)\end{array}$ & $\begin{array}{l}6.7 \\
(2.0)\end{array}$ & $\begin{array}{l}13.6 \\
(2.0)\end{array}$ & -- & -- & 0.001 \\
\hline & s & -- & $\begin{array}{r}20.2 \\
(1.8)\end{array}$ & $\begin{array}{l}13.2 \\
(0.8)\end{array}$ & $\begin{array}{r}12.6 \\
(0.9)\end{array}$ & $\begin{array}{l}14.4 \\
(2.5)\end{array}$ & $\begin{array}{l}6.4 \\
(0.8)\end{array}$ & $\begin{array}{l}7.7 \\
(2.5)\end{array}$ & 0.001 \\
\hline $\begin{array}{l}\text { TOTAL NEEDLE } \\
\text { LENGTH }(\mathrm{cm})\end{array}$ & CR & $\begin{array}{l}165.5 \\
(20.9)\end{array}$ & $\begin{array}{l}272.7 \\
(26.5)\end{array}$ & $\begin{array}{l}129.8 \\
(14.3)\end{array}$ & $\begin{array}{l}66.0 \\
(41.8)\end{array}$ & $\begin{array}{l}135.6 \\
(41.8)\end{array}$ & $-\infty$ & - & 0.001 \\
\hline & S & -- & $\begin{array}{l}333.7 \\
(43.7)\end{array}$ & $\begin{array}{l}195.0 \\
(18.2)\end{array}$ & $\begin{array}{l}162.2 \\
(21.9)\end{array}$ & $\begin{array}{l}180.5 \\
(61.9)\end{array}$ & $\begin{array}{l}104.5 \\
(20.6)\end{array}$ & $\begin{array}{l}74.5 \\
(61.9)\end{array}$ & 0.001 \\
\hline $\begin{array}{l}\text { TOTAL NEEDLE } \\
\text { SURFACE AREA }\end{array}$ & $C R$ & $\begin{array}{l}606.1 \\
(47.8)\end{array}$ & $\begin{array}{l}834.1 \\
(60.5)\end{array}$ & $\begin{array}{l}580.2 \\
(32.8)\end{array}$ & $\begin{array}{l}439.2 \\
(95.7)\end{array}$ & $\begin{array}{l}672.5 \\
(95.7)\end{array}$ & $\cdots$ & -- & 0.01 \\
\hline & s & $-\cdots$ & $\begin{array}{l}795.6 \\
(59.4)\end{array}$ & $\begin{array}{l}681.6 \\
(24.8)\end{array}$ & $\begin{array}{l}638.6 \\
(29.7)\end{array}$ & $\begin{array}{r}816.7 \\
(84.0)\end{array}$ & $\begin{array}{l}396.6 \\
(28.0)\end{array}$ & $\begin{array}{l}521.6 \\
(84.0)\end{array}$ & 0.001 \\
\hline
\end{tabular}

Eaci element is the mean for that brancin rating (standard error). $n$ is the sample number and is listed only once. $P$ is the probability of significance as determined by a OneWay AivOVA. 


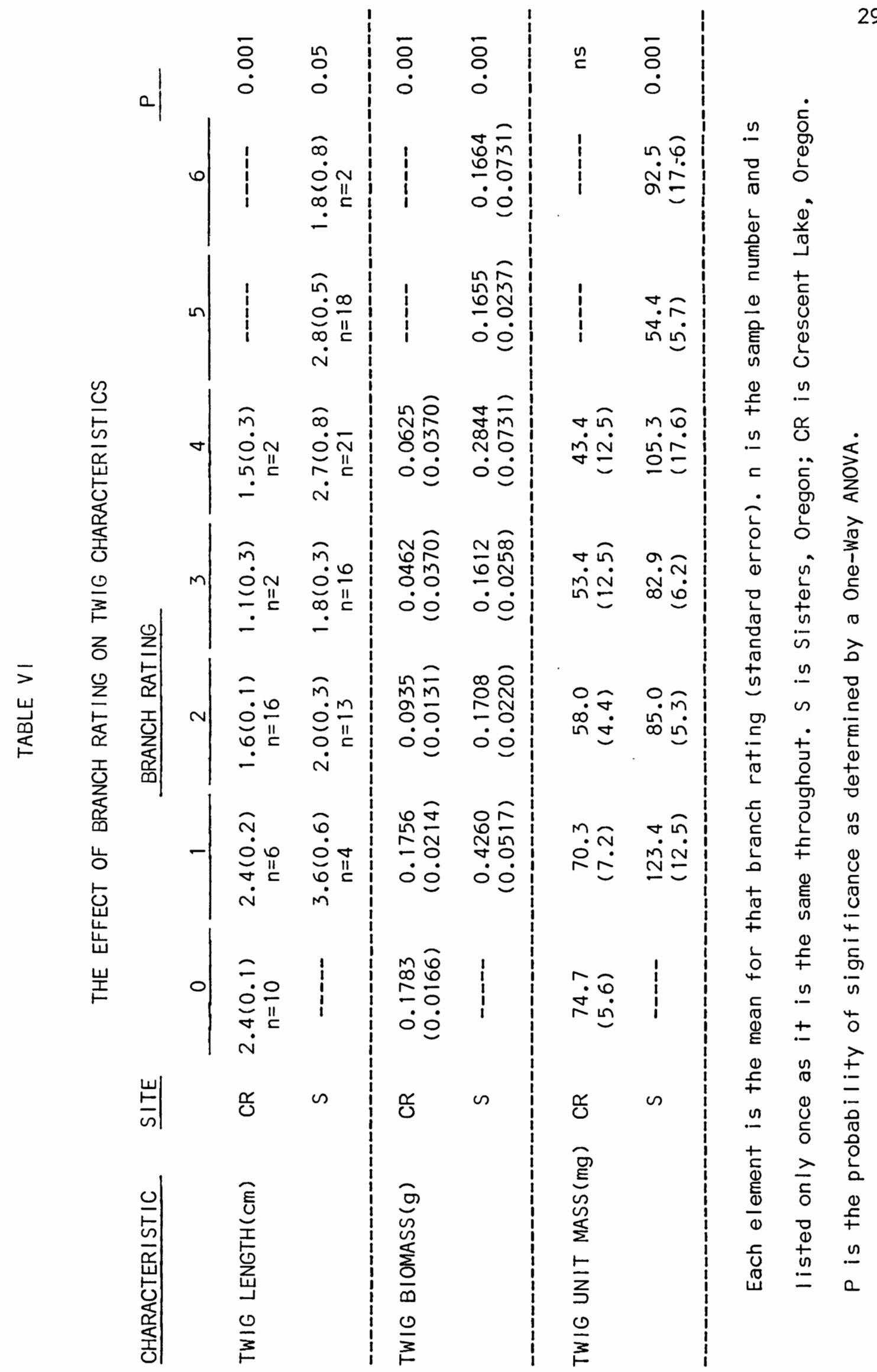


healthy or locally infected branches.

Needle biomass (Tables $V, V I I$ ) showed significant decreases as the branch rating increased. Needle biomass was significantly reduced by the presence of infection, and at the Sister's sites, showed significant reductions between systemically and locally infected branches.

Mass per needle (Tables V, VII) was significantly decreased with increasing infection level. In almost all cases, mass per needle decreased significantly from healthy to locally infected branches. In all cases with systemic samples, the systemic samples had significantly less mass per needle than did the non-systemic ones.

Total length of all the needles on the annual growth segment (Tables $V$, VII) was significantly reduced as the branch rating increased. This number decreased with increasing infection level.

Total surface area (as calculated from Mellor and Tregunna (1972)) (Tables V, VII) was significantly reduced as branch rating increased. As leaf surface area is commonly used as a measure of photosynthetic efficiency, the reductions here could be indicative of a corresponding decrease in the photosynthetic potential of the branch.

Twig length (Tables VI, VIII) was significantly reduced with increasing branch rating. Samples from locally infected branches were significantly shorter than those from healthy branches, while twigs from systemic brooms increased significantly in length over those from locally infected branches.

Even though twig length showed a decrease, followed by an 


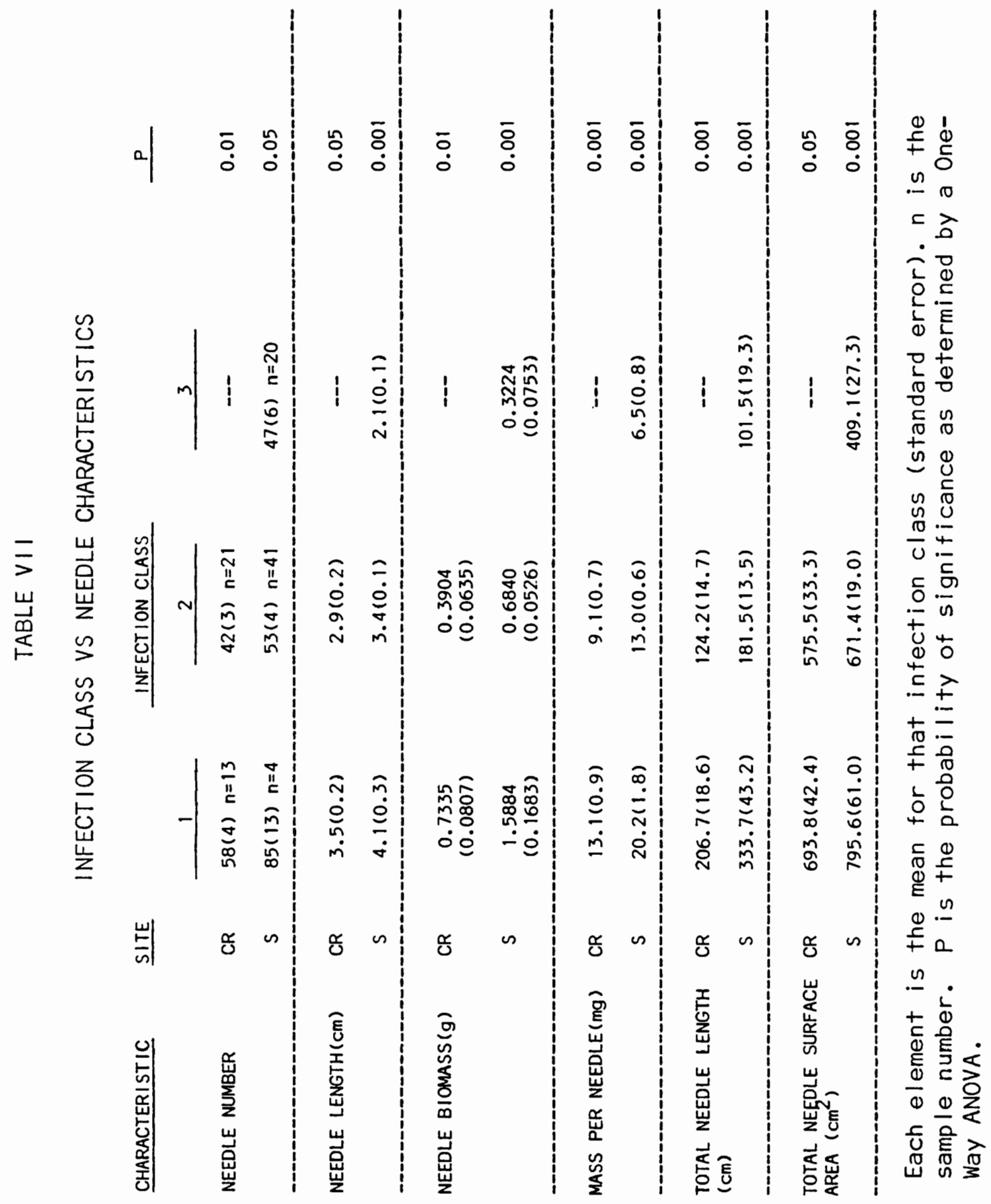




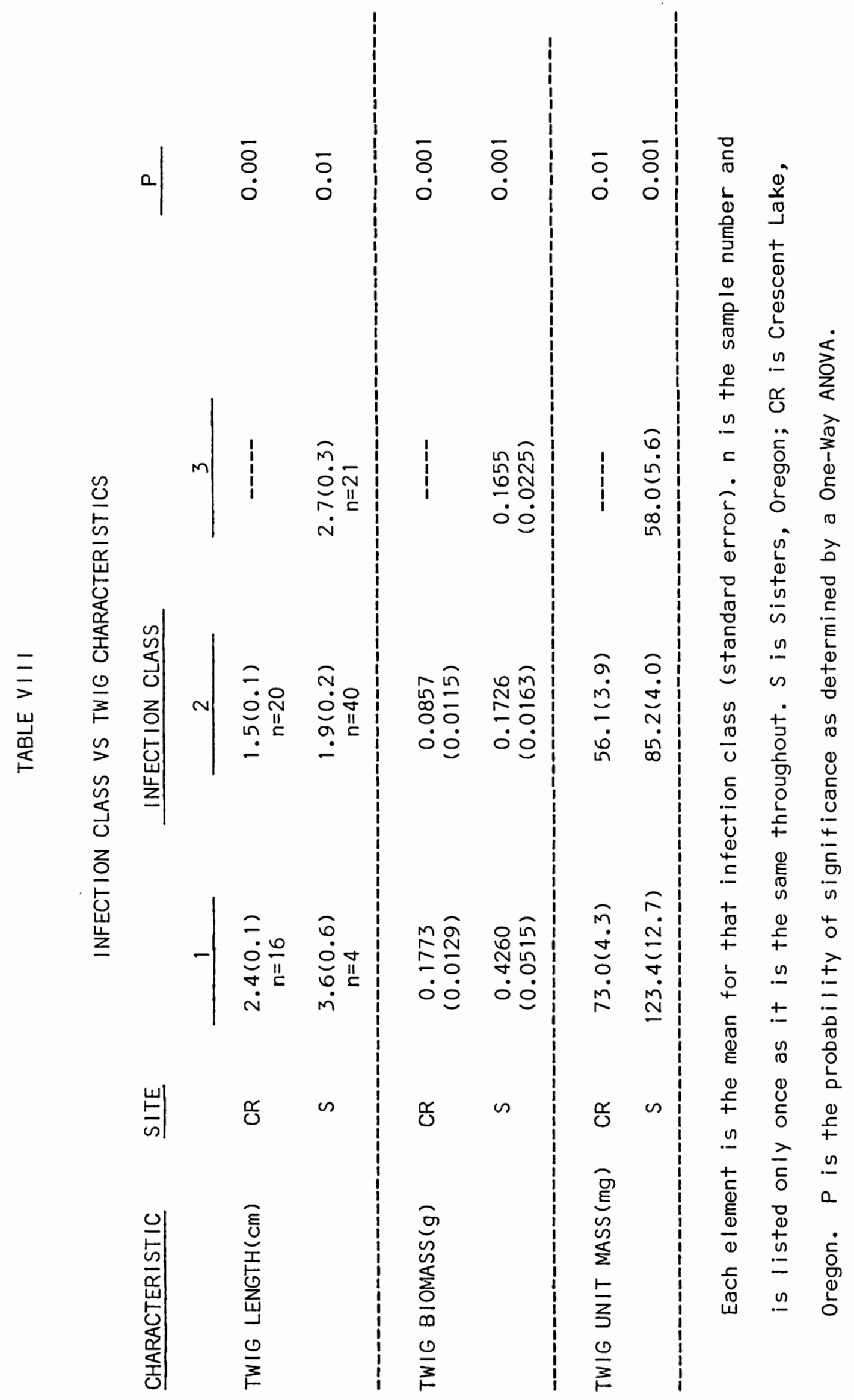


increase, as infection class rose, twig biomass (Tables VI, VIII) was reduced with the presence of infection. And twig unit mass (Tables VI, VIII) was found to be significantly decreased among all three classes. Infection class was found to be a highly significant method of predicting mistletoe's effect on its host's branches. Reductions were found in needle number, needle biomass, and twig biomass from uninfected to infected branches; needle length from healthy and local to systemic branches; and mass per needle, total needle length, total needle surface area, and twig unit mass from healthy to locally infected to systemically infected. Twig length decreased from healthy to locally infected twigs, and then increased in systemically infected twigs.

Starch concentration VS DMR and BRS (infection class).

The starch content of needles vs DMR (Table IX) was found to be significant in only one instance. In this case, it was shown by SNK as a matter of lightly infected vs moderately infected trees, but no clear trends emerged. Starch content of the twigs (Table IX) showed no significant differences in terms of DMR.

Needle starch content was significantly related to infection class (Table $X$ ) in all of the sample dates shown. In both cases, all classes were significantly different from the other classes, with the increasing infection classes ( $i . e$. increasing infection level) causing increasing starch concentrations in the host tissues. The results from the Sister's May 14th sample were found to be not significant. However, this was the sample where there were increased variation in sampling techniques. Even so, the means show the same trends.

Twig starch content (Table $X$ ) was significant only at the 


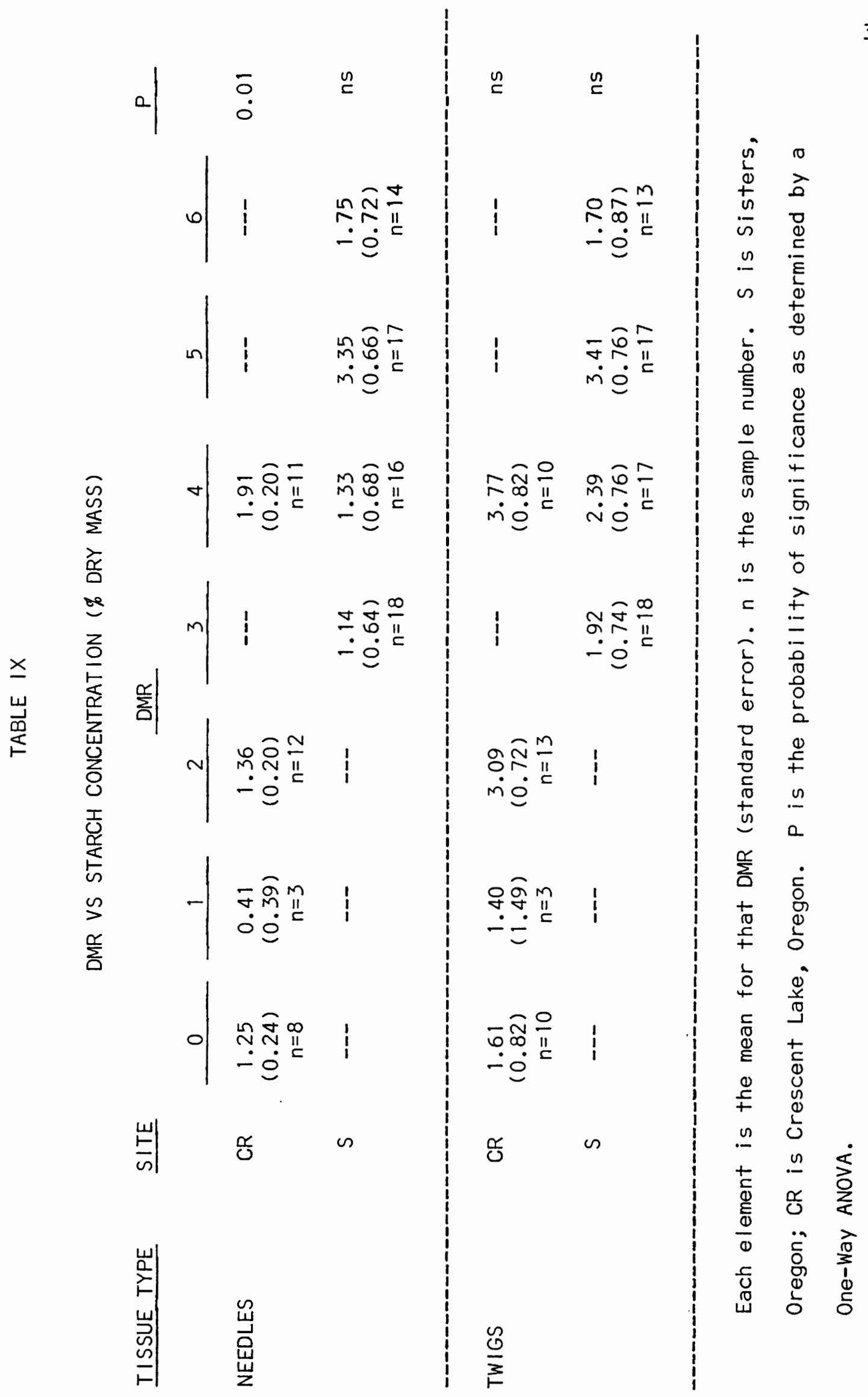




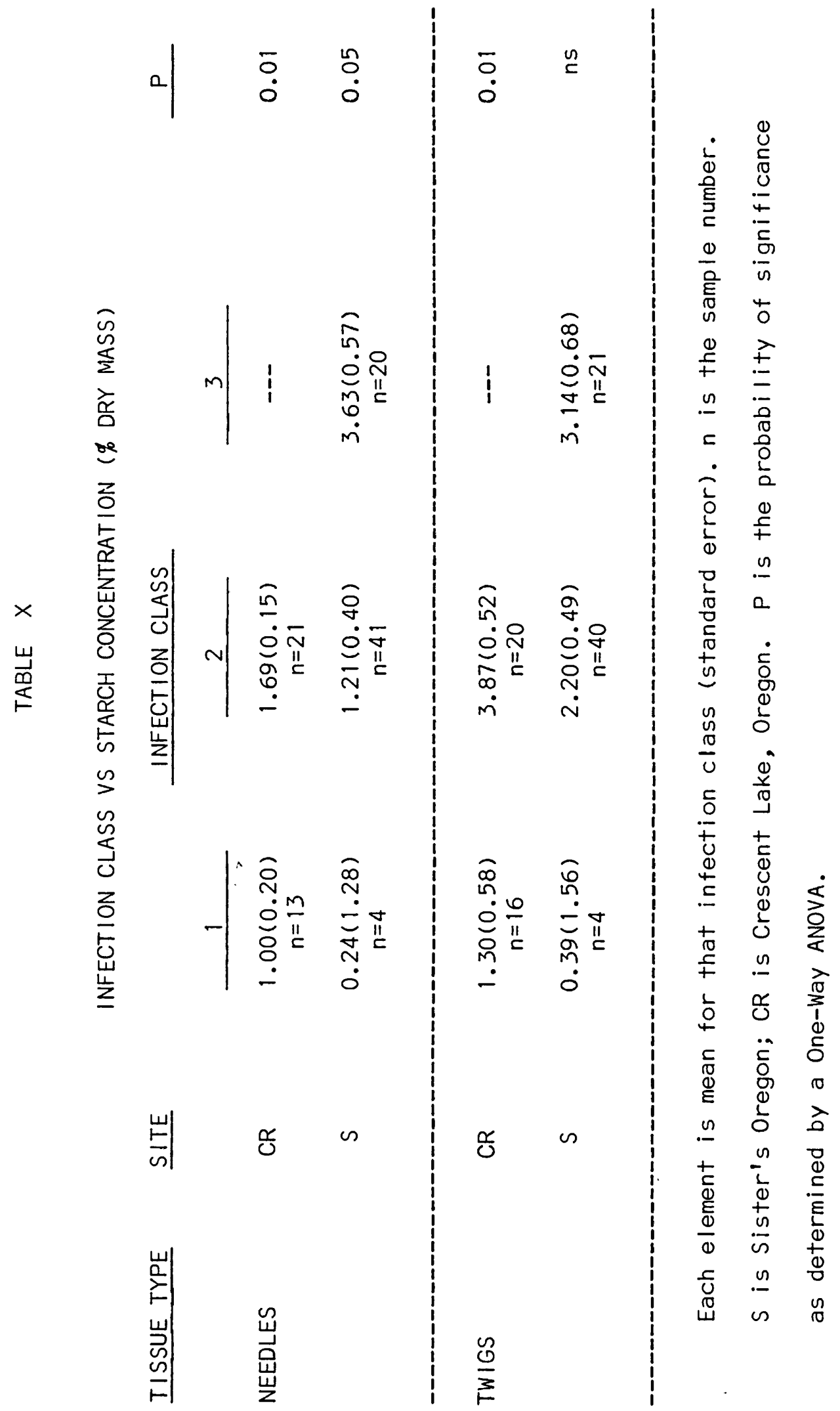


Crescent Lake site, where the locally infected branches had significantly more starch than the healthy branches. Nevertrieless, the twig samples from the Sister's site showed the same increasing tendencies as the needle samples.

The effects that Arceuthobium americanum has ufon the sampled characteristics of its host, Pinus contorta, are summarized in Table XI. 
SUMMARY OF THE EFFECTS OF DWARF MISTLETOE UPON ITS HOST

\section{CHARACTERISTIC}

Needle number

Needle length

Needle biomass

Mass per needle

Total needle length

Total needle surface area

Twig length

Twig biomass

Twig unit mass

Needle starch content

Twig starch content
SISTERS

$\downarrow$

$\downarrow$

$\downarrow$

$\downarrow$

$\downarrow$

$\downarrow$

$+\uparrow$

$\downarrow$

$\downarrow$

$\uparrow$

ns
CRESCENT LAKE

$\downarrow$

$\downarrow$

$\downarrow$

$\downarrow$

$\downarrow$

$\downarrow$

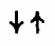

$\downarrow$

$\downarrow$

$\uparrow$

$\uparrow$

Arrows refer to the effect of increasing infection class on the characteristic's mean. $\uparrow$ :means increase; $\downarrow$ : means decrease; ns: means are not significantly different as determined by a One-Way ANOVA. 


\section{DISCUSSION}

Standard forestry techniques commonly use the dwarf mistletoe rating system (DMR) to categorize the infection level of the tree. Implicit in this is the implication that DMR is a useful indicator of the mistletoe's effect on its host. My data show agreement with the previously recorded decreases (Weir, 1916a; 1916b; Gill and Hawksworth, 1964; Hawksworth and Hinds, 1964; Baranyay and Safranyik, 1970; Baranyay and Smith, 1972) in radial growth (Tables I, II, IV) as the level of infection increases. This decrease in the annual allocation of carbon to wood volume is of primary concern to the timber industry. In this aspect, DMR seems to be a good indicator of how the parasite affects the lumber potential of its host. But, in terms of how the parasite alters the host physiologically, DMR seems to be a poor indicator. Besides radial growth, my results showed only needle biomass (Table III) and twig length (Table IV) to be significantly related to DMR and in both cases, it was uninfected vs heavily infected trees where the differences were apparent. These data suggest that DMR is not a very useful indicator of the mistletoe's effects on its host, except in cases of extremely infected trees.

The branch rating system (BRS) seemed to be a better method of estimating the localized effects of dwarf mistletoe upon its host than was DMR. Needle number, needle length, needle biomass, mass per needle, total needle length, total needle surface area (Tables V, VII), 
twig biomass, and twig unit mass (Tables VI, VIII) were all significantly decreased as the level of the branch infection increased. Dwarf mistletoe seems to affect the infected host branches in accord with the type of infection. The effects demonstrated by my data include: fewer needles on infected twigs (figure 6); smaller needles on infected twigs (figure 7), particularly in the case of systemic brooms; less massive needles on infected twigs (figure 8); and each needle having less mass as the infection level rises (figure 9). Calculated total length of all the needles for that year's annual growth segment (figure 10 ), as well as total surface area of those needles (figure 11), were both significantly reduced by infection. Although twig length (figure 12) showed an increase in the presence of systemic infection, the twigs showed a decrease in unit mass (figure 13) as the infection level rose.

The primary effect of dwarf mistletoe upon its host!s physical features appears to be a reduction of carbon being allocated for biomass increases. This is in agreement with the proposed model (figure 4). These data also are in agreement with the known data (Weir, 1916a; 1916b; Gill and Hawksworth, 1964; Hawksworth and Hinds, 1964; Baranyay and Safranyik, 1970; Baranyay and Smith, 1972) on the subject. Tinnin and Knutson (1980) have demonstrated similar conditions in the systemically infected branches of Douglas fir. They too found reductions in twig unit mass and mass per needle, as well as an increase in twig length.

The biomass decrease, found in both needles and twigs, seems to be greater in systemically infected branches than in locally 


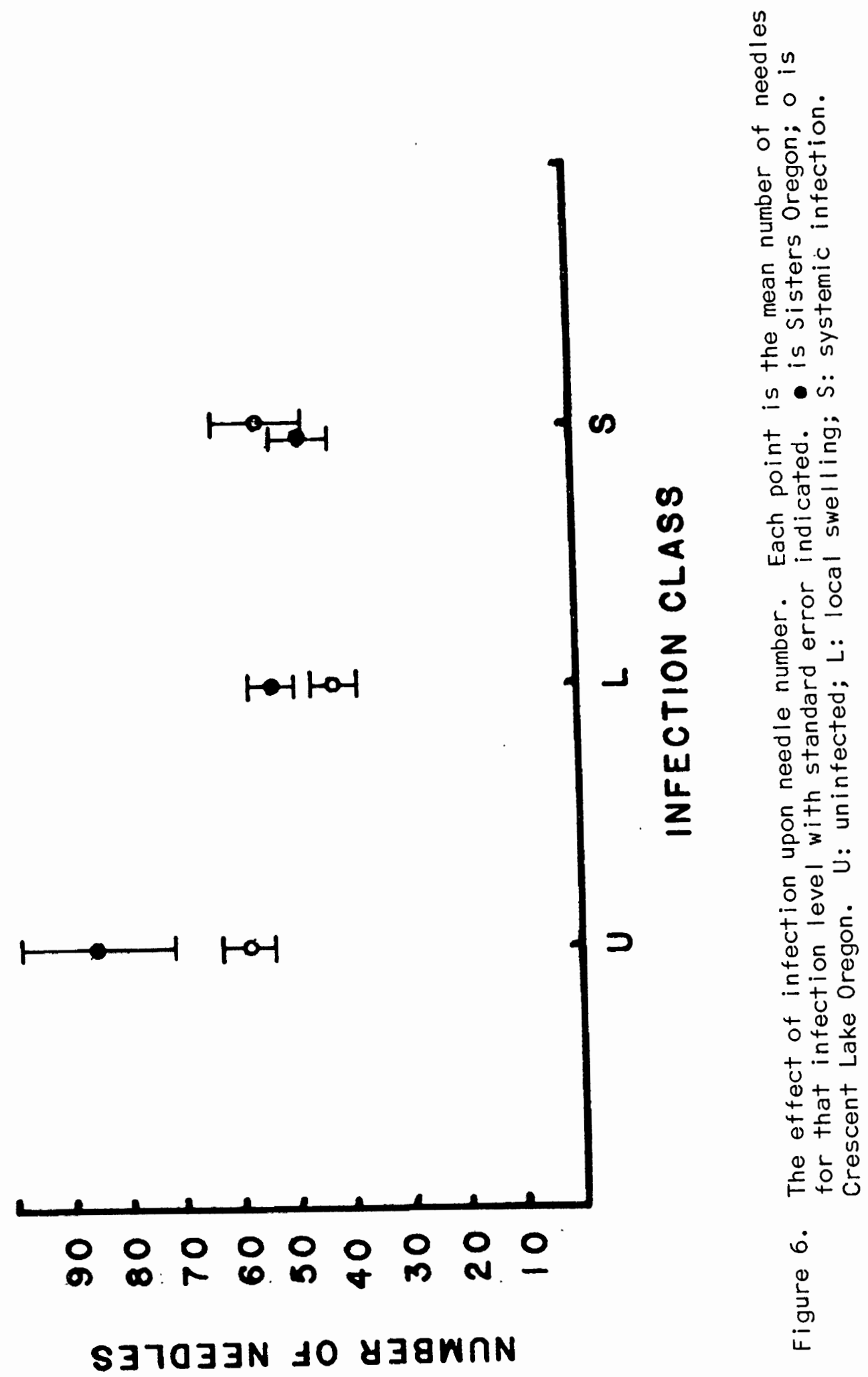




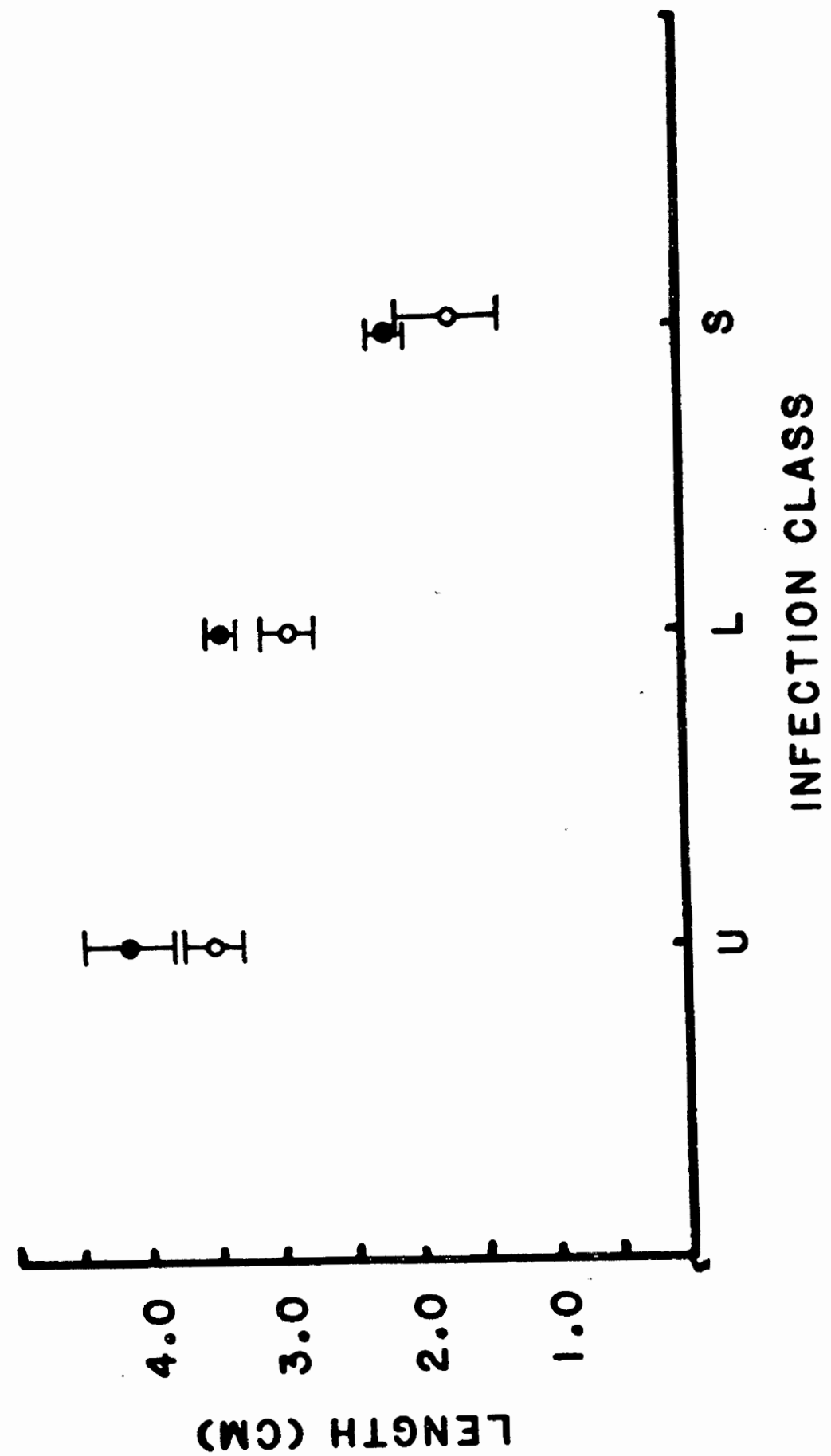




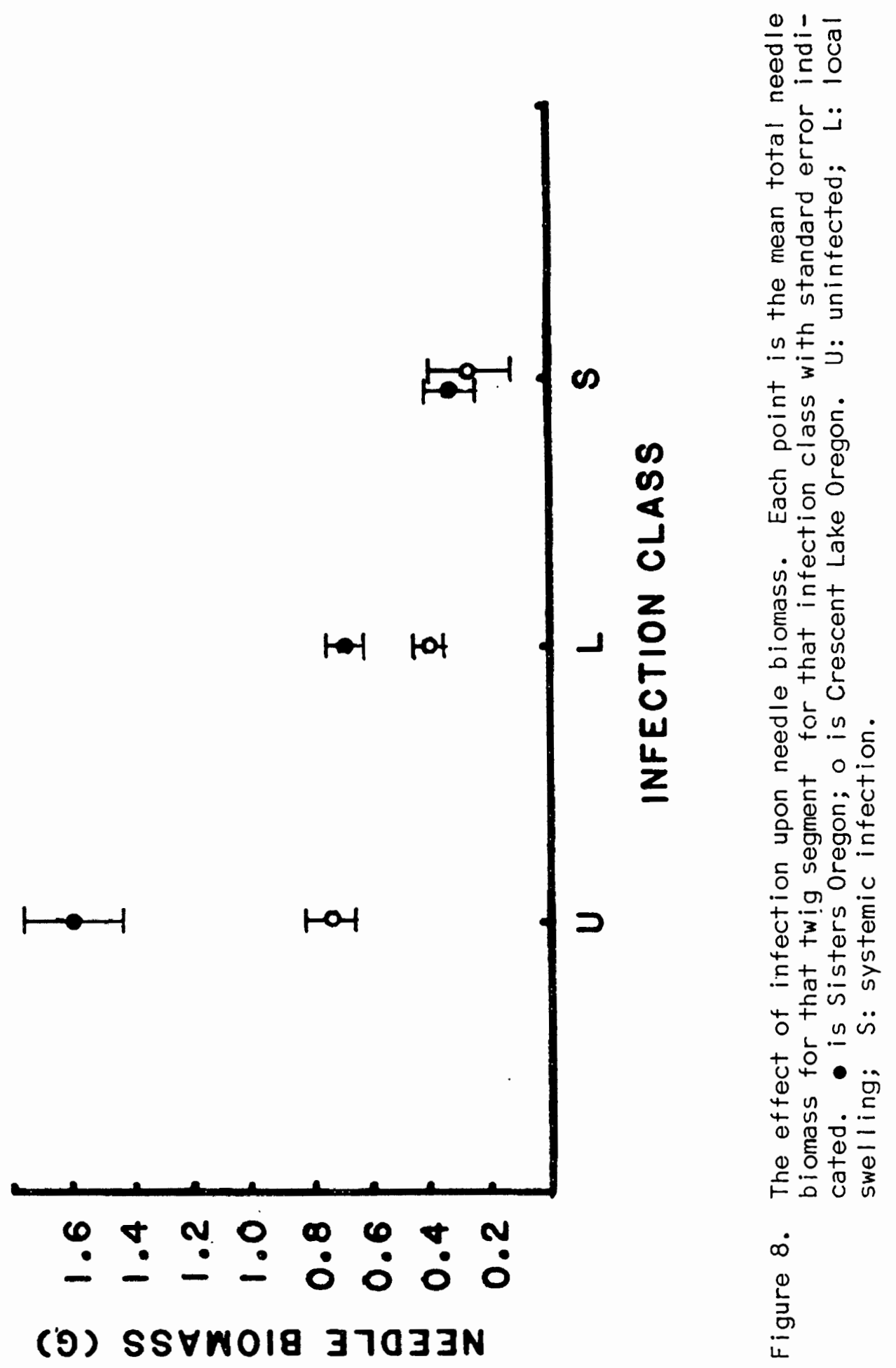




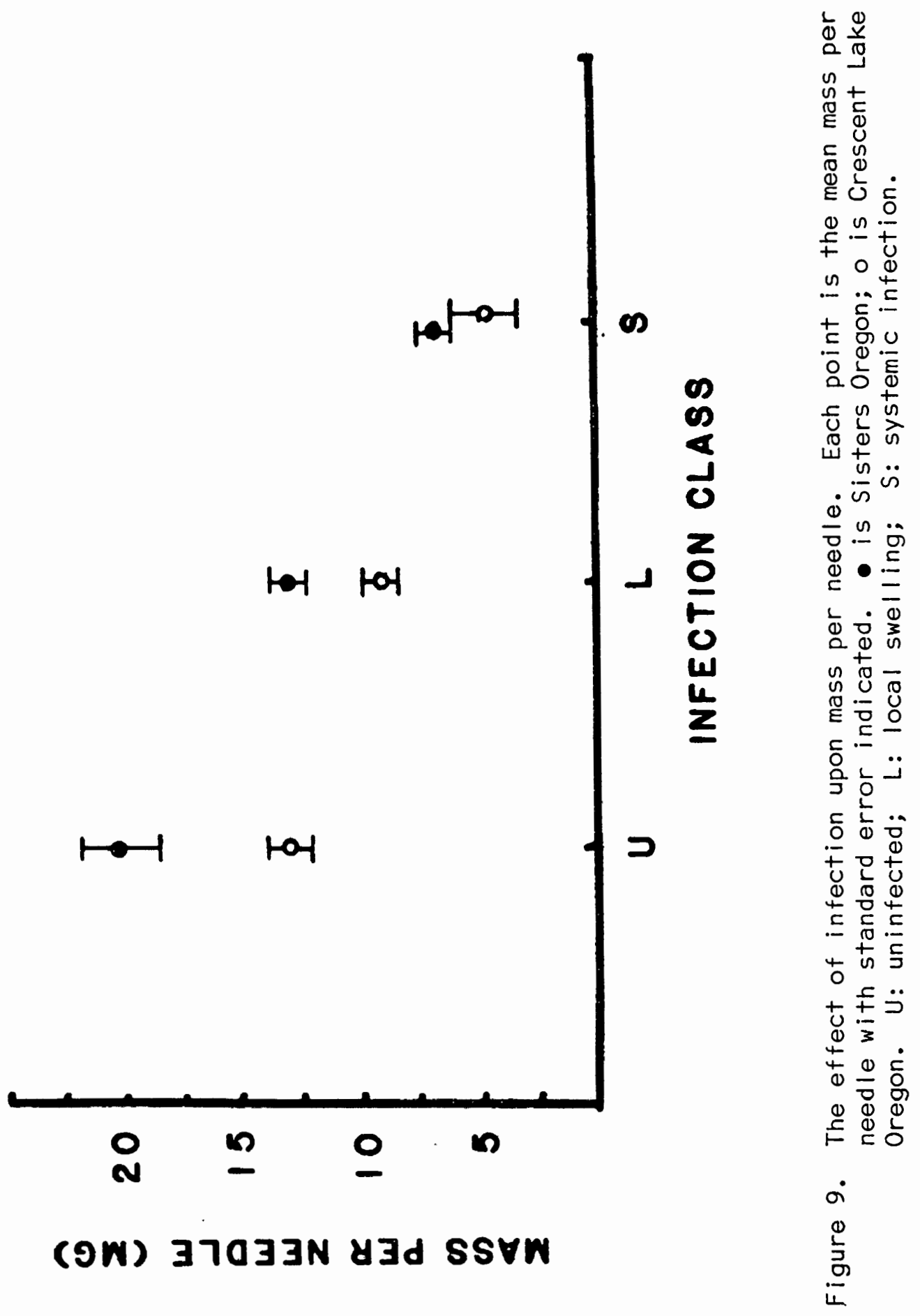




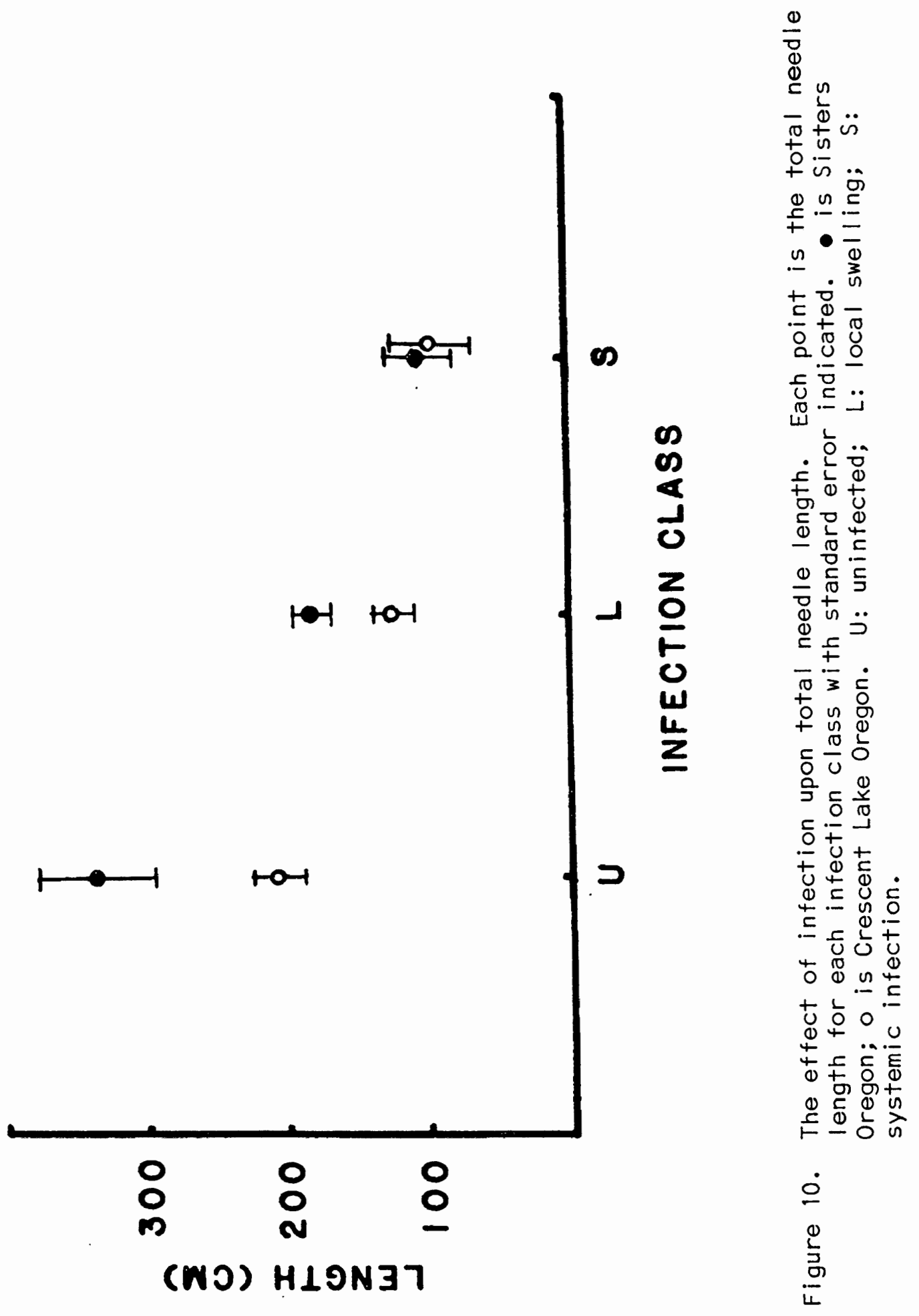




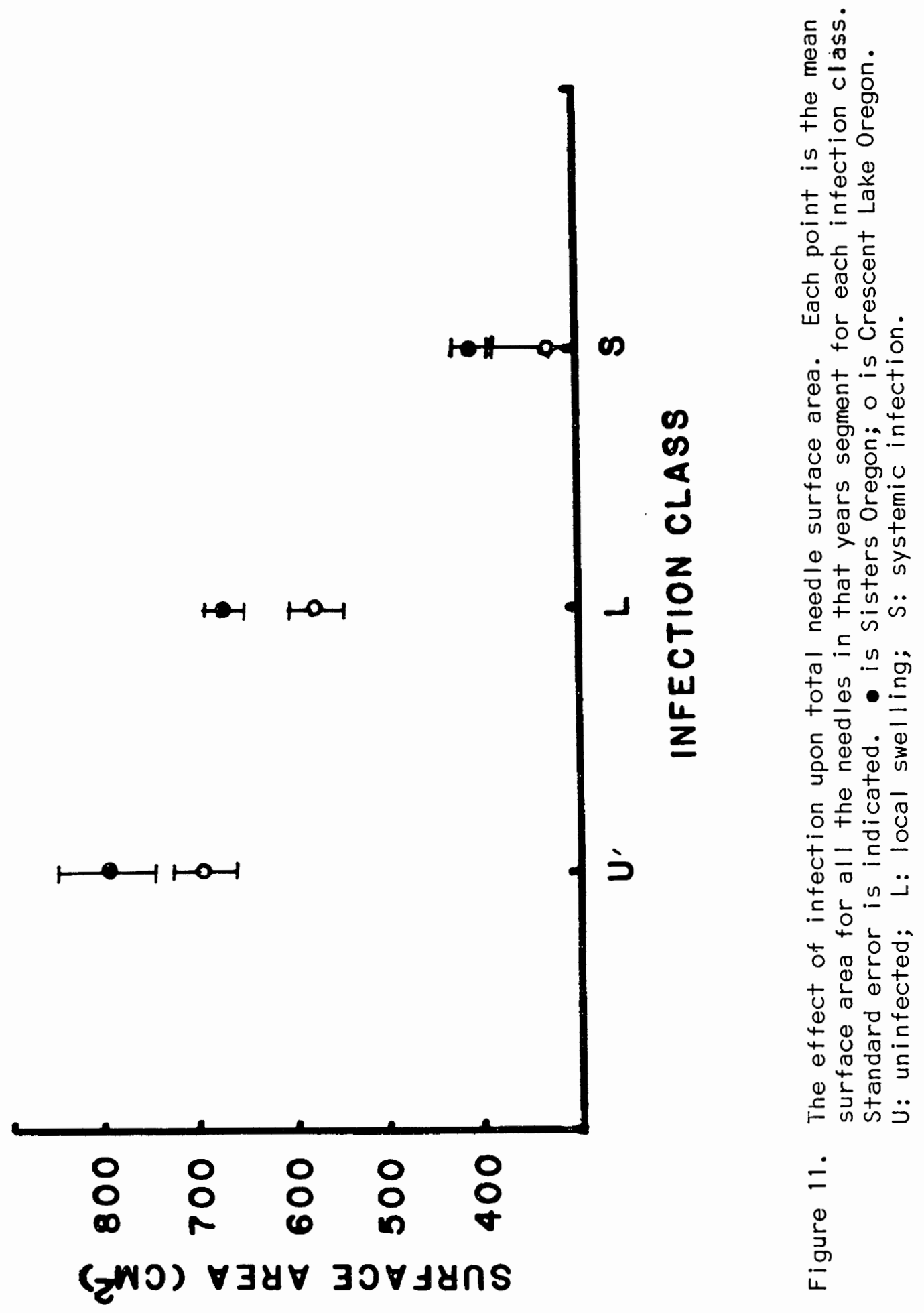




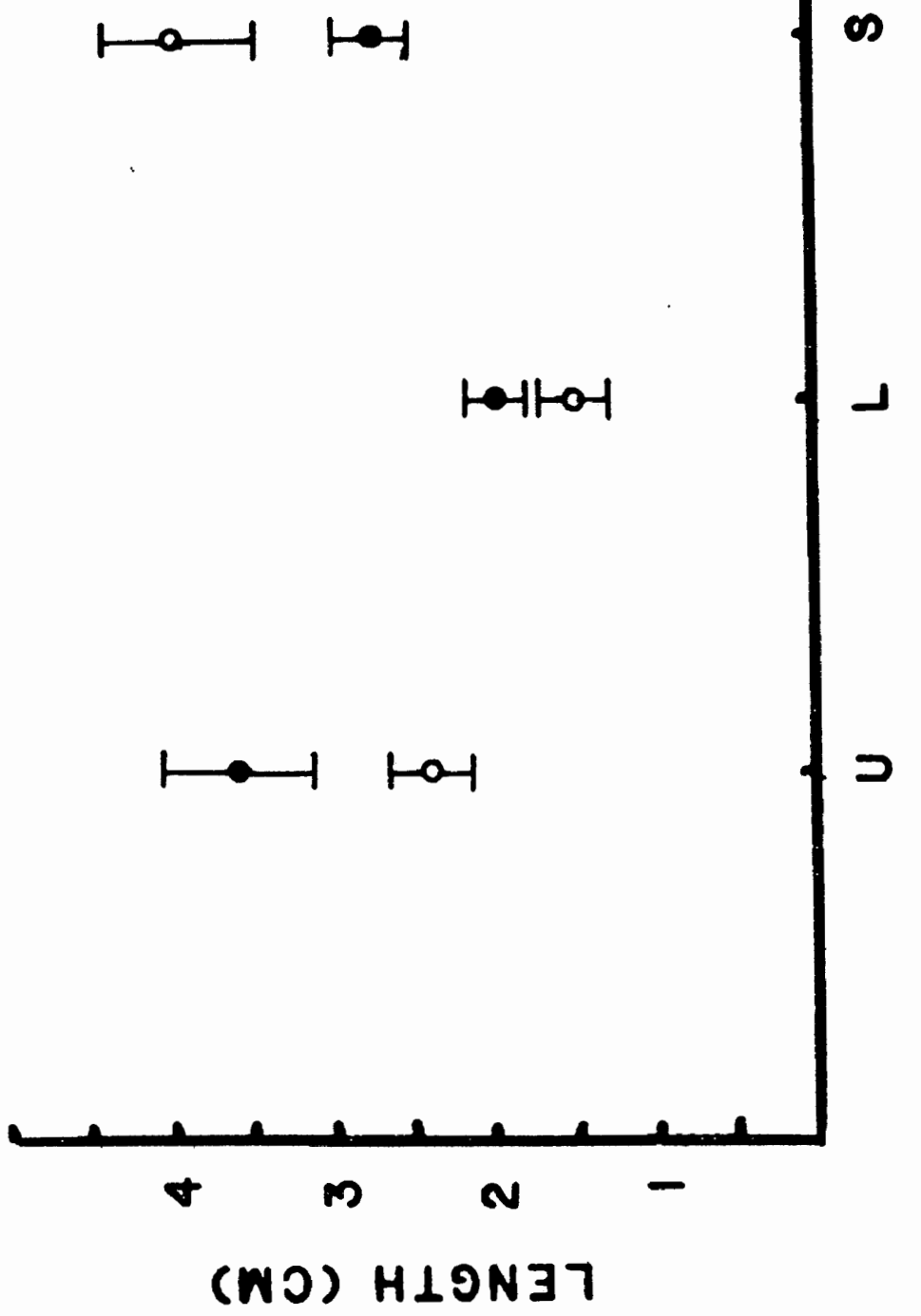

$\frac{5}{\frac{1}{3}}$

ذَ

당

3

品

(0)

$\stackrel{\oplus}{E}+$

足

a

$\infty$

-0
$+\infty$

$\infty$

$+.0$

1

이웡

들

0 离

2
0
0
$w$
$u$
$z$

- 它

兵莎

का ए

$0 \quad \underline{0}+$

II) $\quad$ on

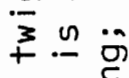

든.

ㄱ.

$5 \dot{0}$ i

$\mp 0 \overline{0}$

뭉으

드.

-

0 t

$+\frac{1}{0}$

4 눈

4

들

点芯高

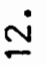

$\frac{0}{3}$ 


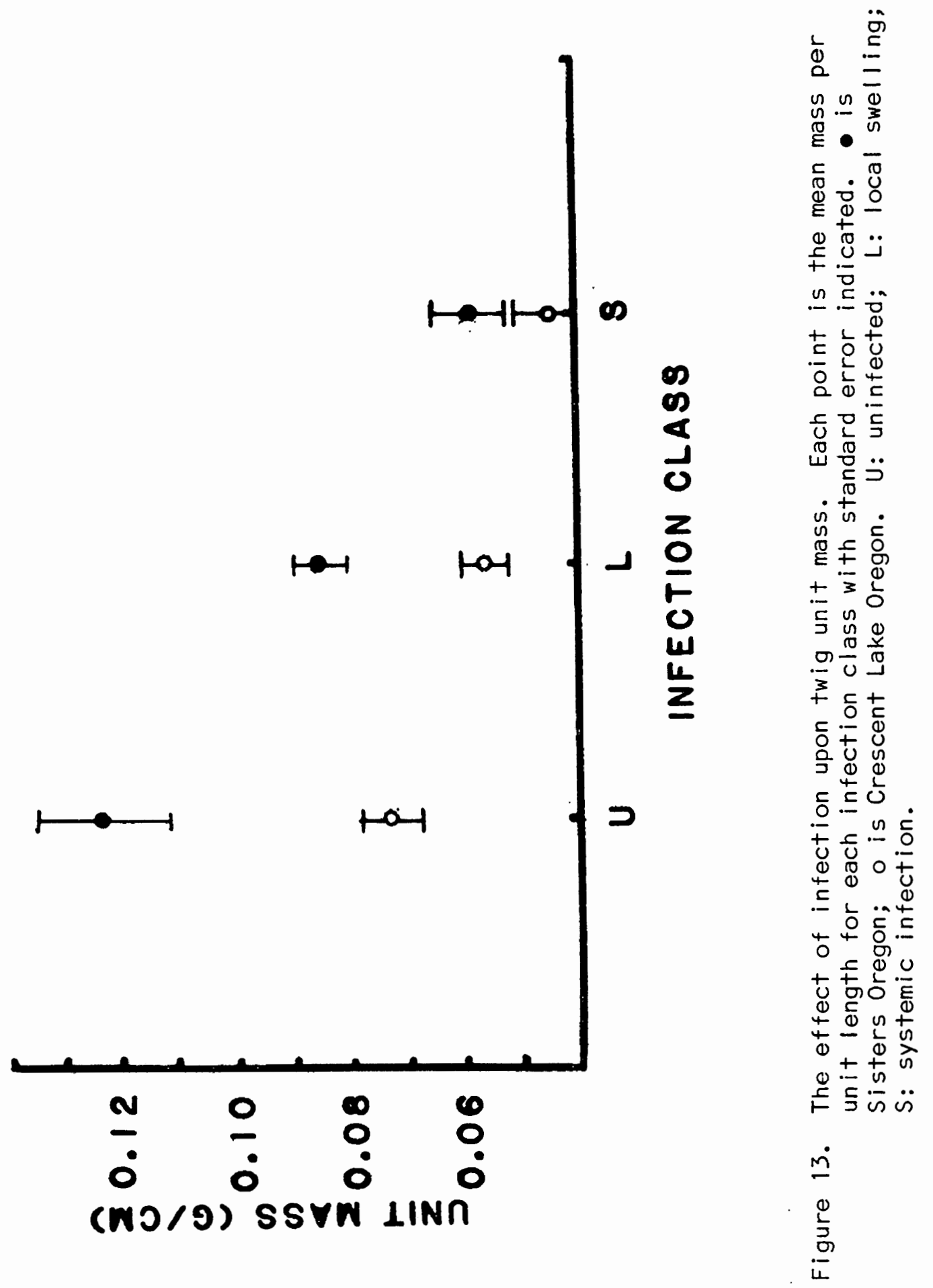


infected branches. This suggests that the systemic type of infection may be more effective in controlling the carbon budget of the host, at least within a single branch.

My data also suggest that there may be a decrease in the photosynthetic efficiency of the host, as witnessed by the decreases in total needle length (figure 10) and total needle surface area (figure 11). But again, this represents losses to the branches, and not the tree.

While there seems to be a decrease in the amount of carbon being annually allocated to twig biomass, especially in systemic infections, it is necessary to keep in mind the unusual growth form of systemic brooms. Systemic brooms have many more actively growing shoots than do healthy branches. Tinnin and Knutson (1980) have reported that even small brooms may weigh 2.5 times more than comparable healthy host branches. As such, systemic brooms represent a significant rearrangement of host carbon, not necessarily a net loss of carbon.

The effect of the parasite on the host as a whole cannot be determined from my data. Recent work in our lab, however, has been conducted on biomass partitioning for the entire tree. Pairs of trees with near identical basal diameters, in close proximity to one another, were selected for comparison. One of each pair was heavily infected, and the other was as lightly infected as could be found. Analyses of the tree pairs reveal a tendency for net biomass and annual biomass allocation to be lower in heavily infected trees. There also seems to be a decrease in the ratio of needles to branches 
in heavily infected trees so that they have a lower overall photosynthetic potential.

\section{Starch}

When DMR was utilized, no significant relationship with starch content was apparent. However, when either the branch rating system (BRS) or infection class were used, the starch content of the needles increased significantly as the level of the branch infection increased (figure 14). The starch content of the twigs did not show as strong a relationship as did the starch content of the needles, but the means still showed the same tendencies ( $f$ igure 15). Starch concentrations for healthy twigs and needles averaged about $1 \%$ dry mass, whereas in infected tissues, means were $2 \%$ dry mass for locally infected tissues, and $3 \%$ dry mass for systemically infected tissues. However, the starch concentration of the local swellings themselves was never greater then $1 \%$ dry mass $(n=5)$ with a mean of $0.1 \%$ dry mass.

The extremely low concentration of starch found in the infected tissue itself is in agreement with previously reported findings of Hull and Leonard (1964a), and makes sense in lieu of the fact that the mistletoe is such a strong carbon sink. The increase in starch content of the needles and twigs of that portion of the branch distal to the infection does not fit the model.

In reviewing the model of the parasite's effect on its host (figure 4), the assumption was that the first place the mistletoe would be drawing off of its host's carbon would be from the storage component (i.e. starch) and then from its structural component (i.e. biomass). On the basis of the observed tendencies of decreasing 


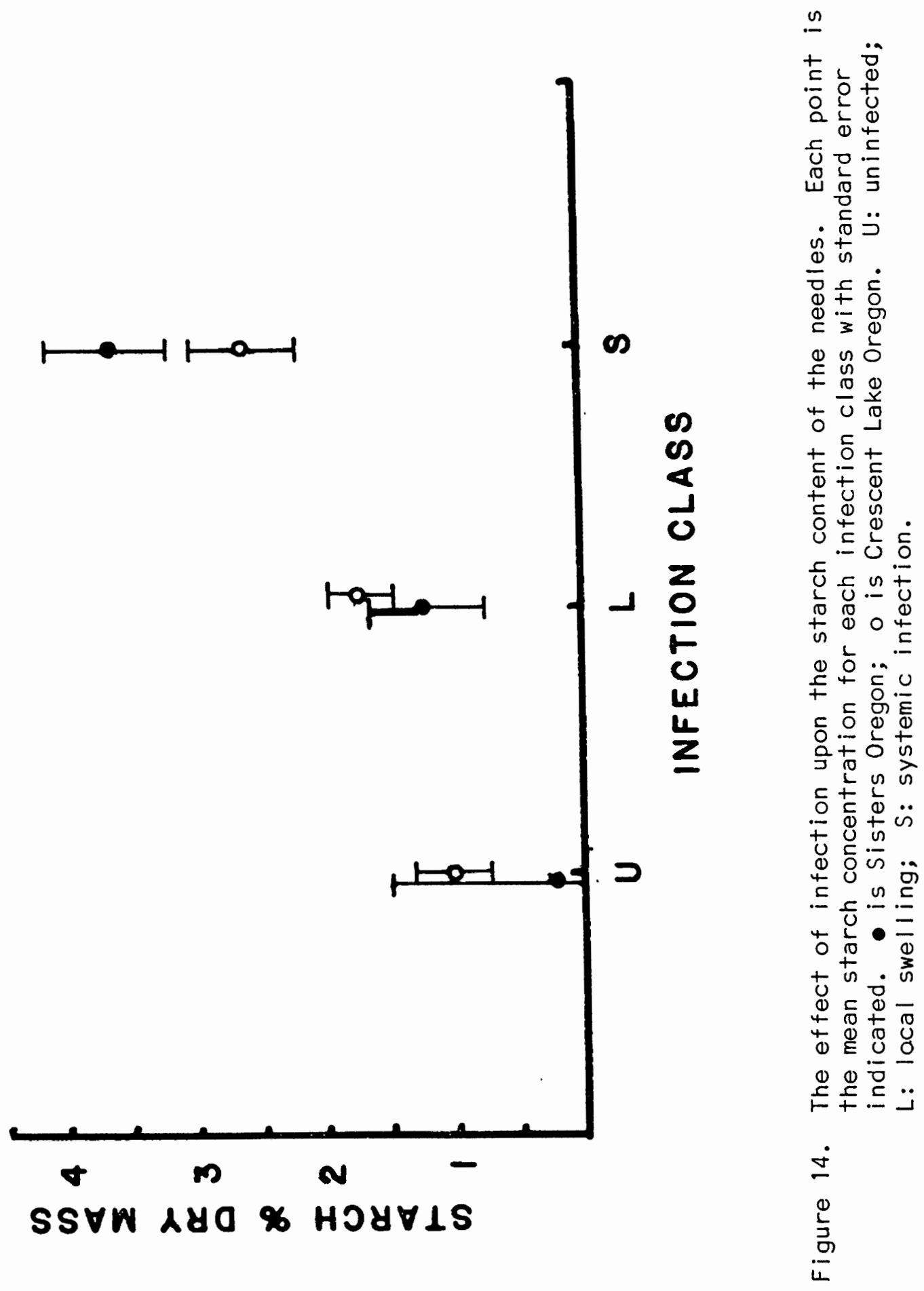




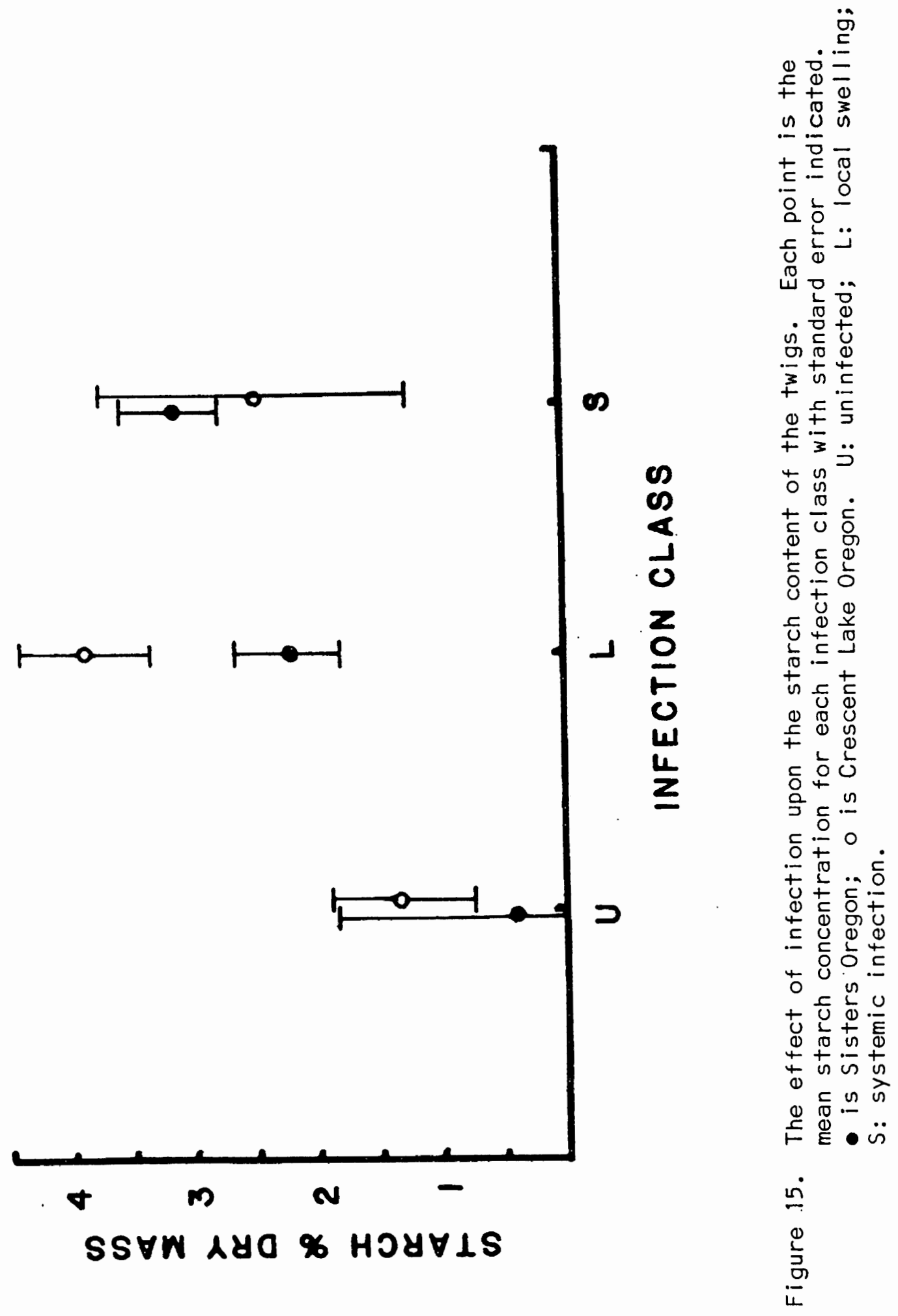


biomass both in branches and for the entire tree, it would appear that the mistletoe is indeed removing carbon from the structural pool. However, for the model to be correct, the mistletoe must be drawing a large amount of its carbon from the host's starch reserves. My data show the latter prediction to be invalid, within the organization of a single branch. It is possible, that in some manner, the mistletoe is altering the host branch so that it has an abnormally large starch reserve. This could be accomplished in a variety of ways: 1) by increasing the rate of photosynthesis in infected branches; 2) by decreasing the rate of respiration in infected branches; and 3) by altering the host's translocation rate, either into or out of the infected host branch. Work being conducted on the first two problems has revealed trends toward decreased respiratory rates in infected plants. Work on the third problem would best be accomplished through the use of labeled compounds.

The mistletoe also could be affecting the host plant so that the entire infected branch is acting as the sink, rather than just the parasite itself. This could be accomplished by altering the hormone concentrations of the infected host tissues, an already documented effect of Arceuthobium (Paquet, 1979). The dwarf mistletoe indirectly could be preventing or at least reducing the translocation rate out of the infected branch and into the rest of the plant. It also could in some manner prevent the plant from converting the excess carbon thus attained, into structural compounds. By maintaining the carbon in a more mutable form than that found in structural compounds, the starch would be readily available to the parasite. 


\section{CONCLUSION}

It has long been recognized that Arceuthobium acts as a strong carbon sink upon its host (Rediske and Shea, 1961; Hull and Leonard, 1964a; 1964b; Leonard and Hull, 1965). The work presented here is a preliminary investigation into the physiological effects that dwarf mistletoe has upon the carbon budget of its host.

Physical features of the host which are altered as a result of mistletoe infection include needle number, mean needle length, needle biomass, mass per needle, total needle length and surface area, twig length, twig biomass, and twig unit mass. In general, the effect of the mistletoe is to decrease the annual allocation of carbon to the infected host tissues.

In contrast, the mistletoe's effect on the host's starch content is to increase it in infected tissue to as much as 15 times that in healthy branches. These two effects are seemingly contradictory. But while other studies have reported overall decreases in host growth, there is no knowledge of host starch content for the entire tree. Until this is known, the mistletoe's effect on the storage component will remain questionable. 


\section{Literature Cited}

Allen, P. J. 1942. Changes in the metabolism of wheat leaves induced by infection with powdery mildew. Am. J. Bot., 29:425-435.

Anderson, R. M. and R. M. May. 1978. Regulation and stability of host-parasite population interactions. 1. Regulatory processes. J. Anim. Ecol., 47:219-247.

Andrews, S. R. and J. P. Daniels. 1960. A survey of dwarfmistletoes in Arizona and New Mexico. U.S. For. Serv. Sta. Paper 49. $17 p p$.

Baranyay, J. A. 1970. Lodgepole pine dwarf mistletoe in Alberta. Can. For. Serv. Publ. 1286. 22pp.

Baranyay, J. A. and L. Safranyik. 1970. Effect of dwarf mistletoe on growth and mortality of lodgepole pine in Alberta. Can. For. Serv. Publ. 1285. 19pp.

Baranyay, J. A. and R. B. Smith. 1972. Dwarf mistletoe in British Columbia and recommendations for their control. Pac. For. Res. Centre. 18pp.

Clark, J. and J. M. Bonga. 1970. Photosynthesis and respiration in black spruce (Picea mariana) parasitized by eastern dwarf mistletoe (Arceuthobium pusillum). Can. J. Bot., 48:2029-2031.

Crofton, H. D. 1971. A model of host-parasite relationships. Parasitology, 63:343-364

Daly, J. M. 1976. The carbon balance of diseased plants: Changes in respiration, photosynthesis and translocation. Encycl. Plant. Physiol., New Ser. 4:450-479.

Dekker, R. F. H. and G. N. Richards. 1971. Determination of starch in plant material. J. Sci. Food Agric., 22:441-444.

De Le Harpe, A. C., J. H. Visser and N. Grobbelaar. 1981. Photosynthetic characteristics of some south African parasitic flowering plants. Zeitschrift für Pflanzenphysiologie., 103: 265-276.

Fisher, J. T. 1975. Water relations of dwarf mistletoe on pine. Ph.D. Thesis. Colorado State University. 193pp. 
Gill, L. S. and F. G. Hawksworth. 1964. Dwarfmistletoes of lodgepole pine. For. Pest Leaflet 18., 7pp.

Haissig, B. E. and R. E. Dickson. 1979. Starch measurement in plant tissue using enzymatic hydrolysis. Physiol. Plant., 47:151-157.

Hawksworth, F. G. 1958a. Rate of spread and intensification of dwarfmistletoe in young lodgepole pine stands. J. Forest., 56(6):404407.

Hawksworth, F. G. 1958b. Survey of lodgepole pine dwarfmistletoe on the Roosevelt, Medicine Bow, and Bighorn National Forests. For. Serv. Sta. paper 35. 13pp.

Hawksworth, F. G. and D. P. Graham. 1963. Spread and intensification of dwarf mistletoe in lodgepole pine reproduction. J. Forest., $61(8): 587-591$.

Hawksworth, F. G. and T. E. Hinds. 1964. Effects of dwarf mistletoe on immature lodgepole pine stands in Colorado. J. Forest., $62(1): 27-32$.

Hawksworth, F. G. and A. A. Lusher. 1956. Dwarfmistletoe survey and control on the Mescalero-Apache reservation, New Mexico. J. Forest., 54:384-390.

Hawksworth, F. G. and D. Wiens. 1972. Biology and Classification of Dwarf Mistletoes (Arceuthobium). U. S. For. Serv. Agric. Handbook 401 . 234pp.

Hawksworth, F. G. and D. Wiens. 1976. Arceuthobium oxycedri and its segregates $A$. jun iperi-procerae and $\underline{A}$. azoricum (Viscaceae). Kew Bul1., 31(1):71-80.

Hawksworth, F. G. and D. Wiens. 1977. Arceuthobium (Viscaceae) in Mexico and Guatemala: Additions and range extensions. Brittonia, $29(4): 411-418$.

Hawksworth, F. G. and D. Wiens. 1980. A new species of Arceuthobium (Viscaceae) from central Mexico. Brittonia, 32(3):348-352.

Hull, R. J. and O. A. Leonard. 1964a. Physiological aspects of parasitism in mistletoes (Arceuthobium and Phoradendron).l. The carbohydrate nutrition of mistletoe. Pl. Physiol., 39(6): 996-1007.

Hull, R. J. and O. A. Leonard. 1964b. Physiological aspects of parasitism in mistletoes (Arceuthobium and Phoradendron). 11. The photosynthetic capacity of mistletoe. PI. Physiol., 39(6): 1008-1017. 
Inman, R. E. 1962. Relationships between disease intensity and stage of disease development on carbohydrate levels of rust-infected bean leaves. Phytopathology, 32:1207-1211.

Johnson, D. W., F. G. Hawksworth, and D. B. Drummond. 1981. Yield loss of lodgepole pine stands to dwarf mistletoe in Colorado and Wyoming National Forests. Plant Disease, 65:437-438.

Knutson, D. M. and R. O. Tinnin. 1981. Arceuthobium cyanocarpum in Oregon. Plant Disease, May 1981. pp445.

Kozlowski, T. T. and T. Keller. 1966. Food relations of woody plants. Bot. Rev., 32(4):293-382.

Kramer, P. J. and T. T. Kozlowski. 1979. Physiology of Woody Plants. Academic Press. N. Y. $811 \mathrm{pp}$.

Kuijt, J. 1960. Morphological Aspects of Parasitism in the Dwarf Mistletoes (Arceuthobium). Univ. of Calf. Publ., 30(5):337-436.

Leonard, O. A. and R. J. Hull. 1965. Translocation relationships in and between mistletoes and their hosts. Hi Igardia, 37(4):115-153.

lacDonald, P. W. and G. A. Strobel. 1970. Adenosine diphosphateglucose pyrophosphorylase control of starch accumulation in rust-infected wheat leaves. Plant Physiol., 46:126-135.

Mark, W. R. and C. P. P. Reid. 1971. Lodgepole pine-dwartmistletoe xylem water potentials. For. Sci., 17(4):470-471.

McDowell, L. L. 1964. Physiological relationships between dwarf mistletoe and ponderosa pine. Ph.D. thesis. Oregon State Univ. $63 p p$.

Mellor, G. E. and E. B. Tregunna. 1972. The relationship between leaf area and leaf dry weight of three conifer species grown on three sources of nitrogen. Can. J. For. Res., 2:377-379.

Miller, J. R. and R. D. Tocher. 1975. Photosynthesis and respiration of Arceuthobium tsugense (Loranthaceae). Am. J. Bot., 62(7): 765-769.

Misra, P. C. 1970. Regionalization of the physiological effects of mistletoe infection. Indian J. of Exp. Biol., 8:324-325.

Munteanu, C. and M. Kalo. 1971. Unele aspecte biochimice ale parazitismului in familia Loranthaceae. Continutul in zahar total si reducator la Viscum album L. si gazda sa, Juglans nigra L. (Some biochemical aspects of parasitism in Loranthaceae. Amount of total and reducing sugar in Viscum album L. and its host, Juglans nigra L.). Cluj. Univ. Babes-Bolyai Stud. Ser. Biol., $16(2): 69-75$. 
Odum, E. P. 1959. Fundamentals of Ecology. 2nd. ed. W. B. Saunders Co. Philadelphia, Pa. 546pp.

Odum, E. P. 1971. Fundamentals of Ecology. 3rd. ed. W. B. Saunders Co. Philadelphia, Pa. 574pp.

Paquet, P. 1979. Seasonal variations in cytokinin activity and content in two species of dwarf mistletoes and their hosts. PH.D. thesis. Portland State Univ. 71pp.

Pianka, E. R. 1978. Evolutionary Ecology. 2nd. ed. Harper and Row, Publ. New York, New York. 397pp.

Price, P. W. 1980. Evolutionary Biology of Parasites. Princeton Univ. Press. Princeton, New Jersey. 237pp.

Rediske, J. H. and K. R. Shea. 1961. The production and translocation of photosynthate in dwarf mistletoe and lodgepole pine. Am J. Bot., 48:447-452.

Ricklefs, R. E. 1979. Ecology. 2nd. ed. Chiron Press Inc., New York, New York. 966pp.

Singh, M; D. V. Singh; P. C. Misra; K. K. Tewari and P. S. Krishnan. 1968. Biochemical aspects of parasitism by angiosperm parasites: Starch accumulation in angiosperm parasites. Physiol. Plant., $21: 525-538$.

Smith, D., L. Muscatine, and D. Lewis. 1969. Carbohydrate movement from autotrophs to heterotrophs in parasitic and mutualistic symbiosis. Biol. Rev., 44:17-90.

Sokal, R. R. and F. J. Rohlf. 1969. Biometry. W. H. Freeman and Co. San Francisco, Ca. 776pp.

Tinnin, R. O. and D. M. Knutson. 1980. Growth characteristics of the brooms on douglas-fir caused by Arceuthobium douglassii. For. Sci., 26(1):149-158.

Tinnin, R. O., F. G. Hawksworth, and D. M. Knutson. 1982. Witches' broom formation in conifers infected by Arceuthobium Spp.: An example of parasitic impact upon community dynamics. Am. Midl. Nat., 107(2):351-359.

Wardlaw, 1. F. 1968. The control and pattern of movement of carbohydrate in plants. Bot. Rev., 34:79-105.

Waring, R. H., W. G. Thies and D. Muscato. 1980. Stem growth per unit of leaf area: A measure of tree vigor. For. Sci., 26(1):112-117.

Webb, W. L. and J. J. Karchesy. 1977. Starch content of Douglas-fir defol iated by Tussock moth. Can. J. For. Res., $7(1): 186-188$. 
Webb, W. L. 1981. Relation of starch content to conifer mortality and growth loss after defoliation by douglas-fir tussock moth. For. Sci., 27:224-232.

Weir, J. R. 1916a. Mistletoe injury to conifers in the Northwest. U. S. Dept. Agric. Bull. 360. 39pp.

Weir, J. R. 1916b. Larch mistletoe: Some economic considerations of its injurous effects. U. S. Dept. Agric. Bull. 317. 25pp.

Weir, J.R. 1918. The effects of mistletoes on young conifers. J. of Agric. Res., 12(11):715-719. 
APPENDIX 


\section{LEGEND OF TABLES}

ALL OF THE PROCEEDING TABLES CONTAIN THE FOLLOWING:

Each element is: mean \pm standard error (sample error)

S:

Sisters, Oregon

$\mathrm{Cr}$ :

Crescent Lake, Oregon

$P:$

is the probability of significance as determined by a One-Way ANOVA

significant value of $r(P<0.05)$ based on a linear regression for several values of $y$ for each value of $\underline{x}$ 


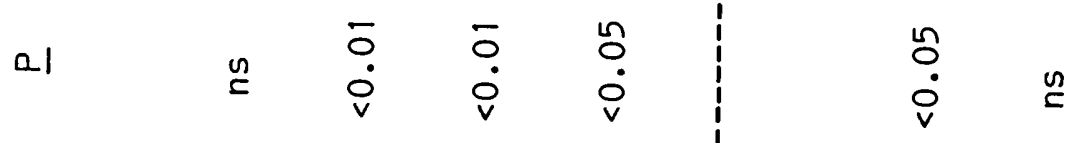

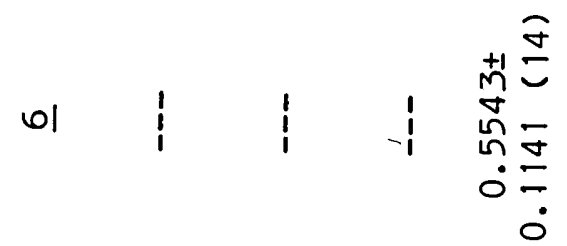

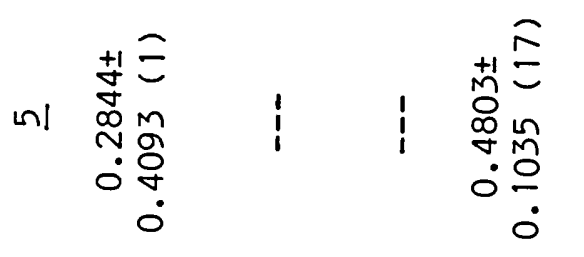

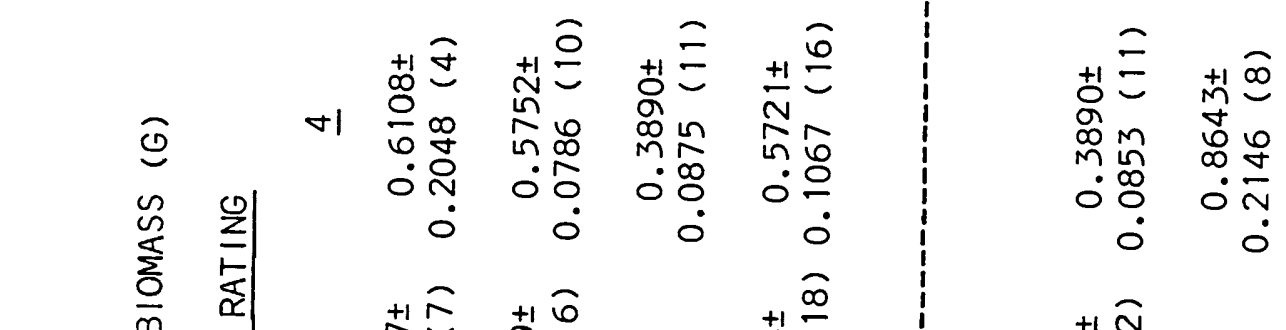

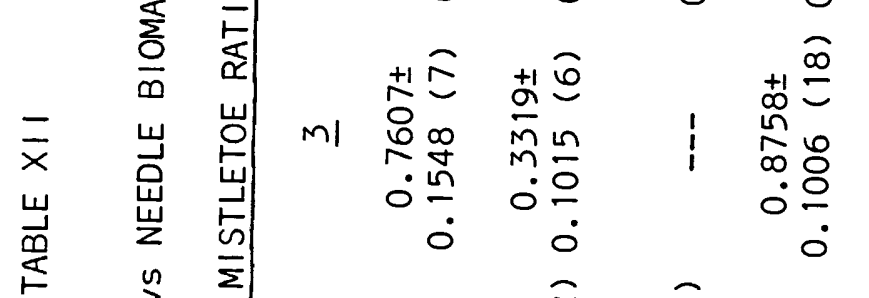

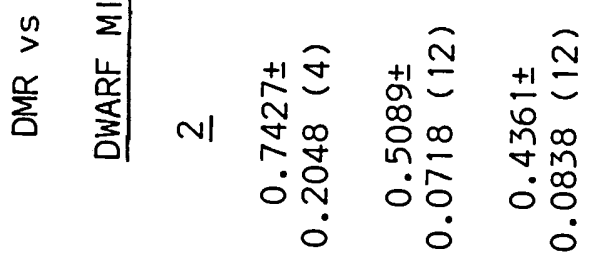

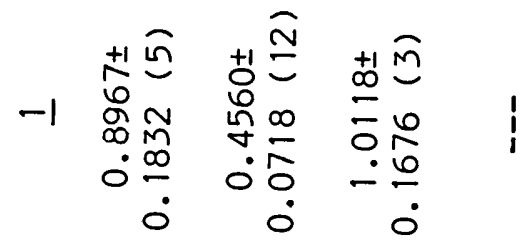

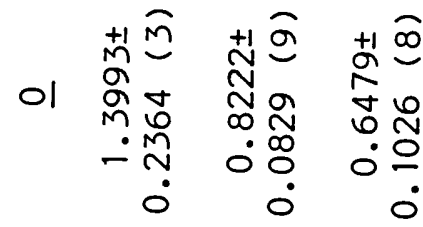

$$
\begin{aligned}
& \text { 纍 }
\end{aligned}
$$

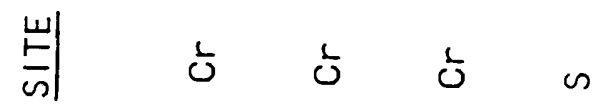

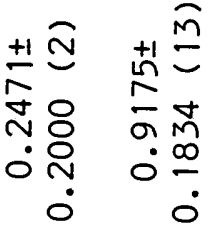

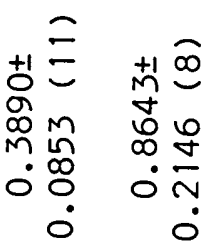

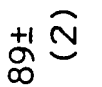

$$
\begin{aligned}
& \text { จุ๊ । } \\
& \text { ㅇํㅇ }
\end{aligned}
$$

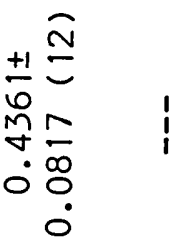

$$
\begin{aligned}
& \text { 筧高 }
\end{aligned}
$$

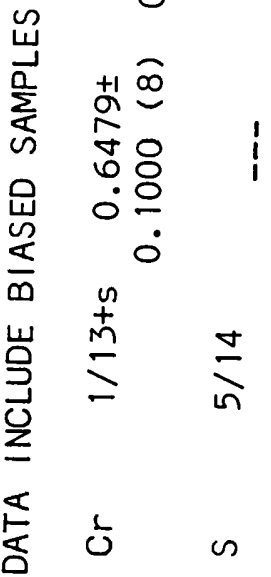




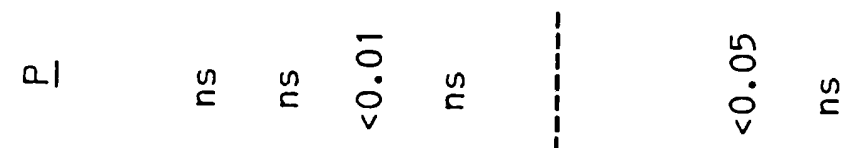

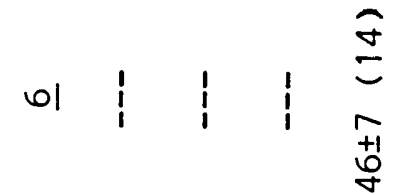

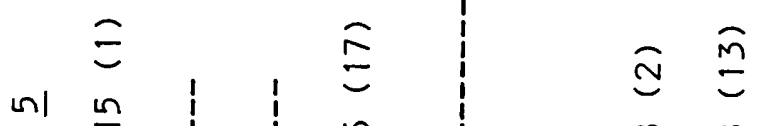

$$
\begin{aligned}
& \begin{array}{ll}
\infty & \infty \\
+1 & +1 \\
\stackrel{+}{\forall} & \stackrel{+}{\forall}
\end{array}
\end{aligned}
$$

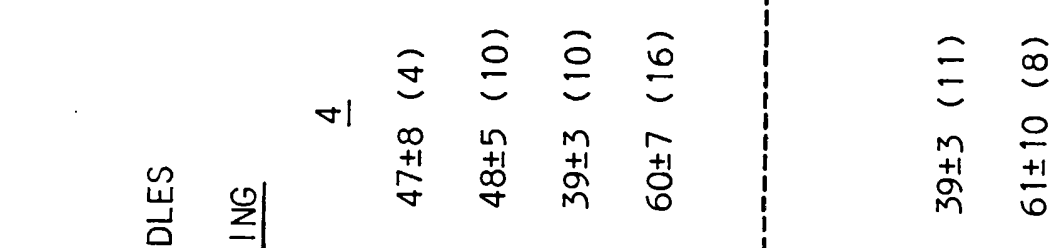

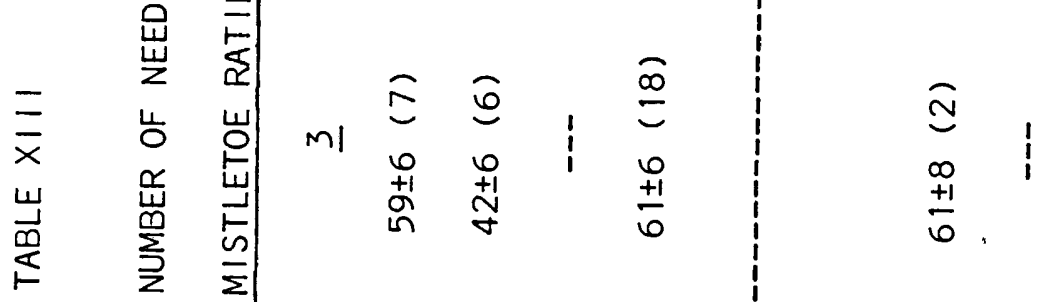

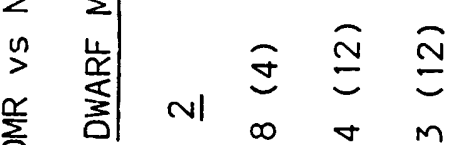

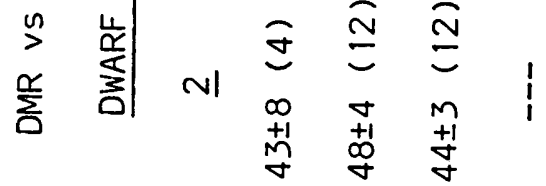

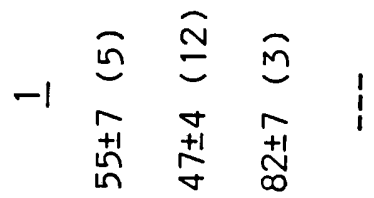

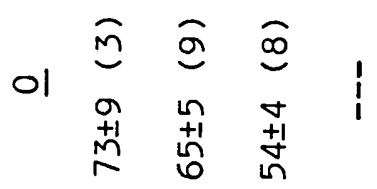

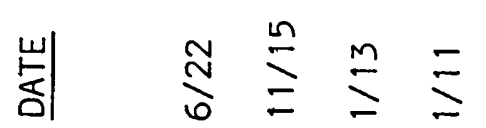

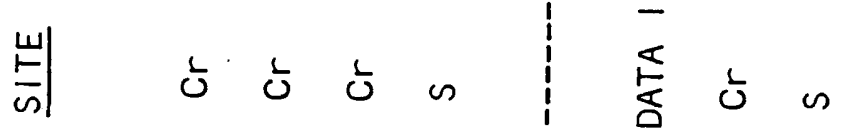




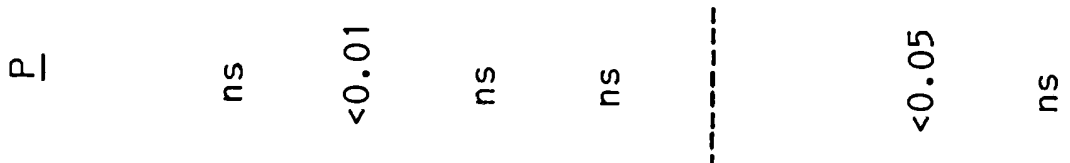

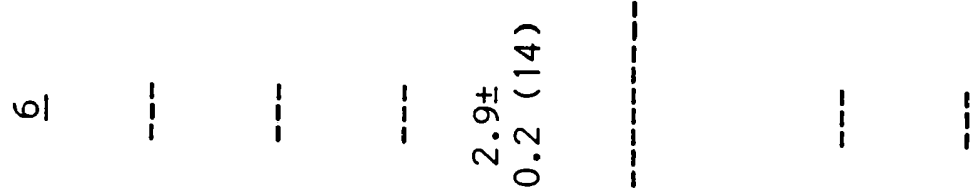

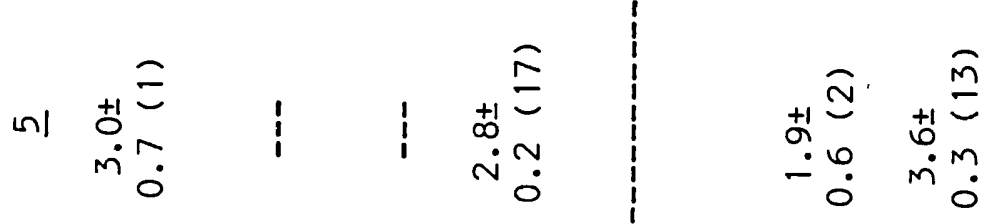

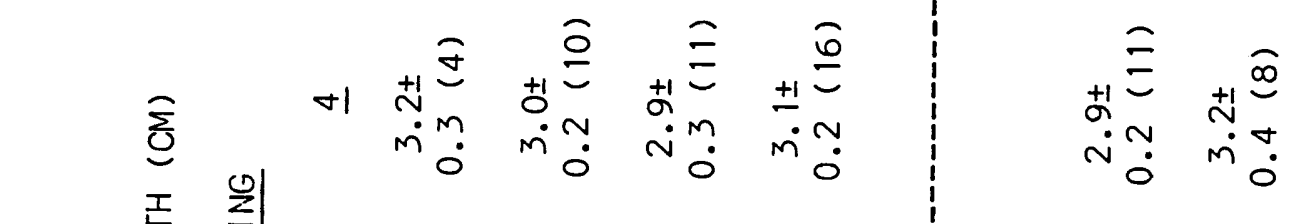

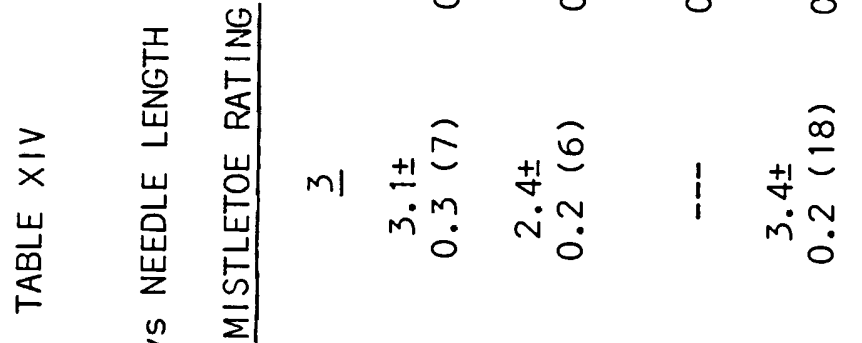

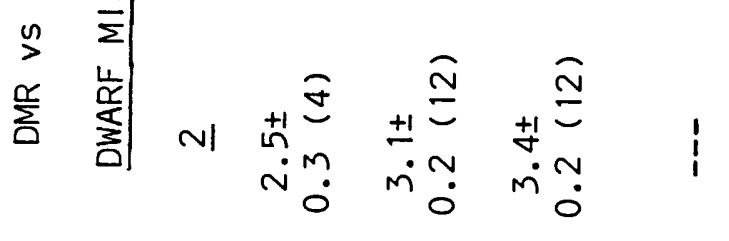

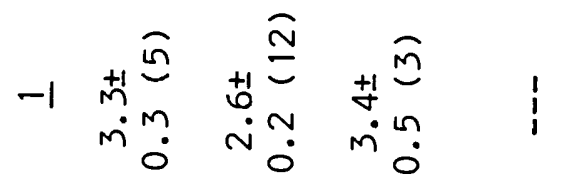

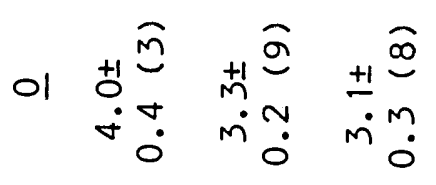

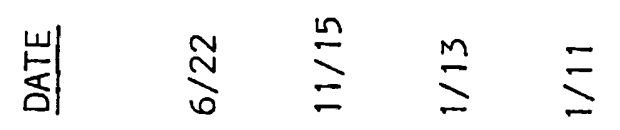

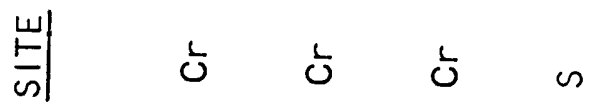

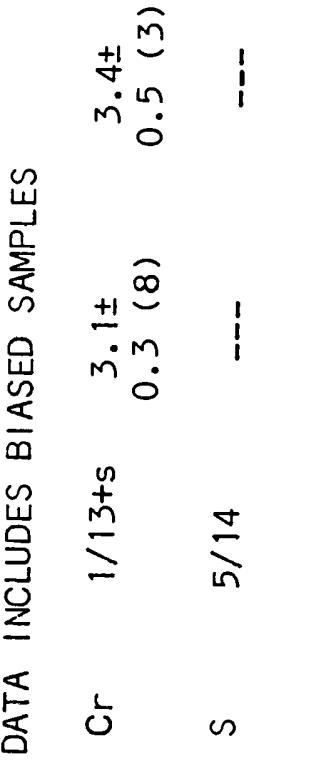

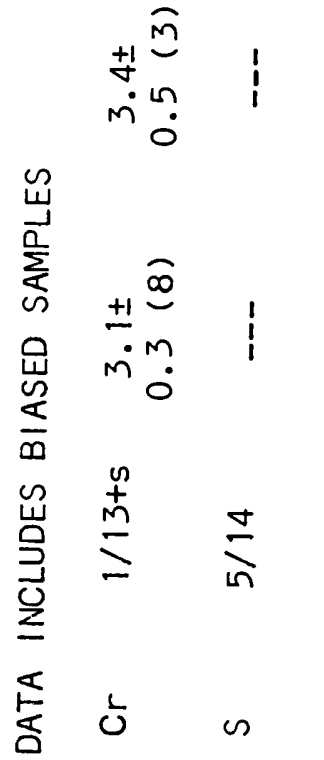




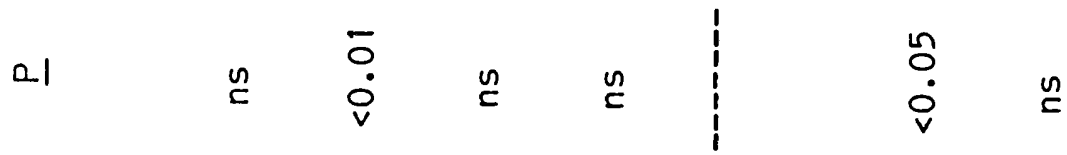

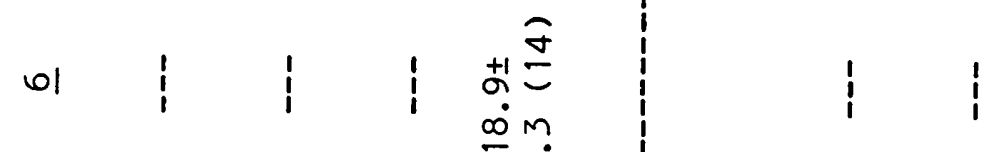

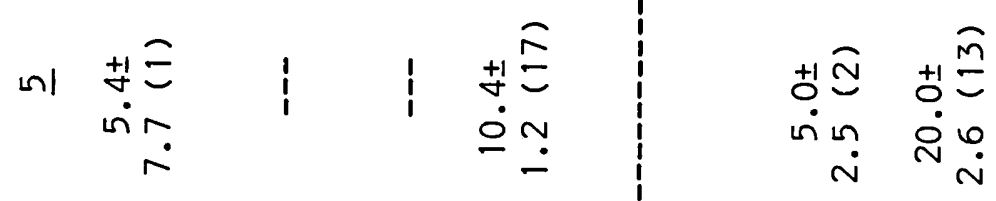

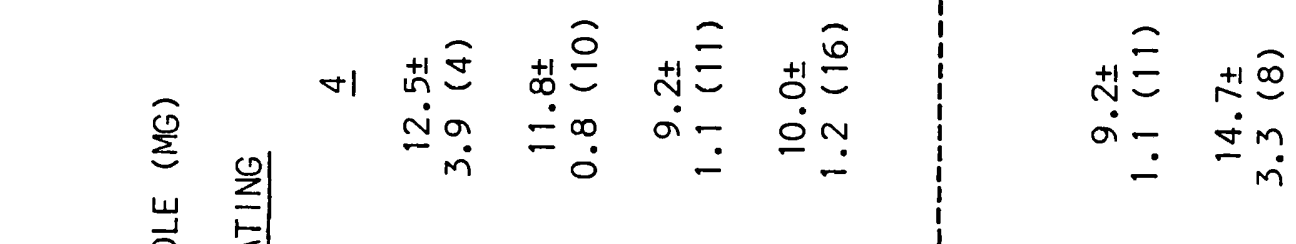

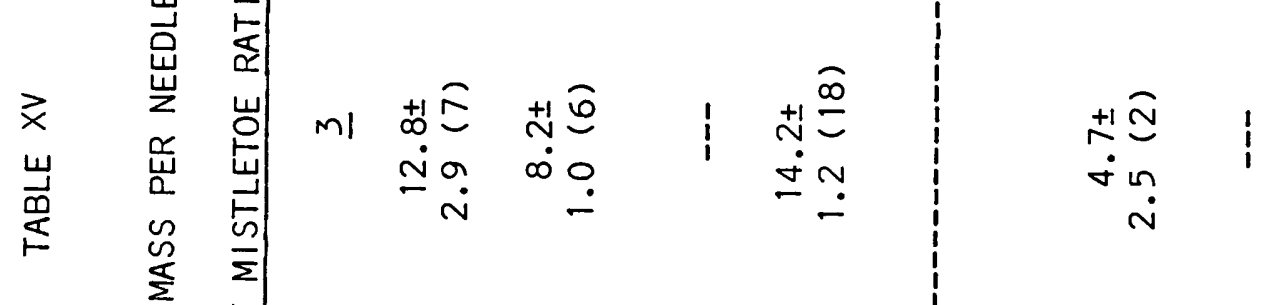

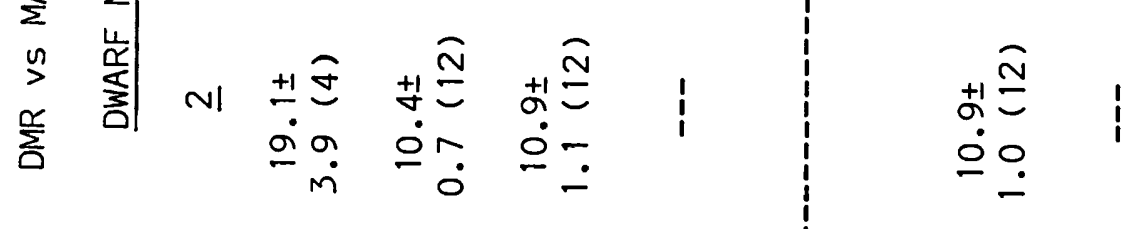

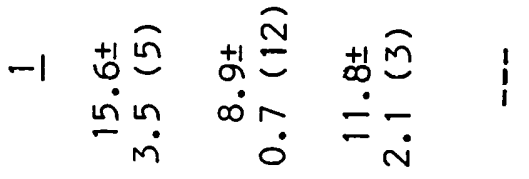

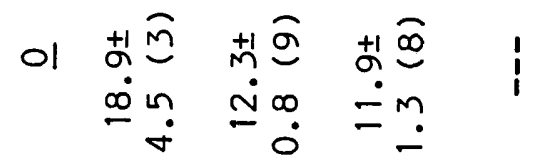

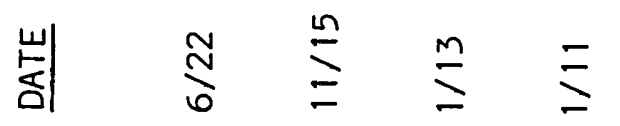

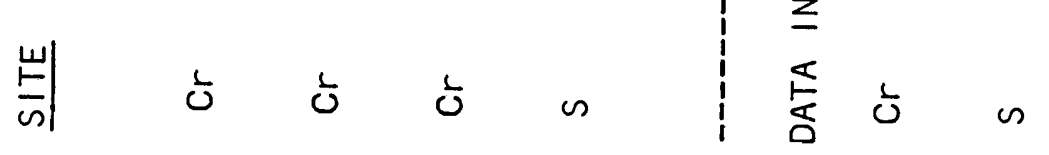




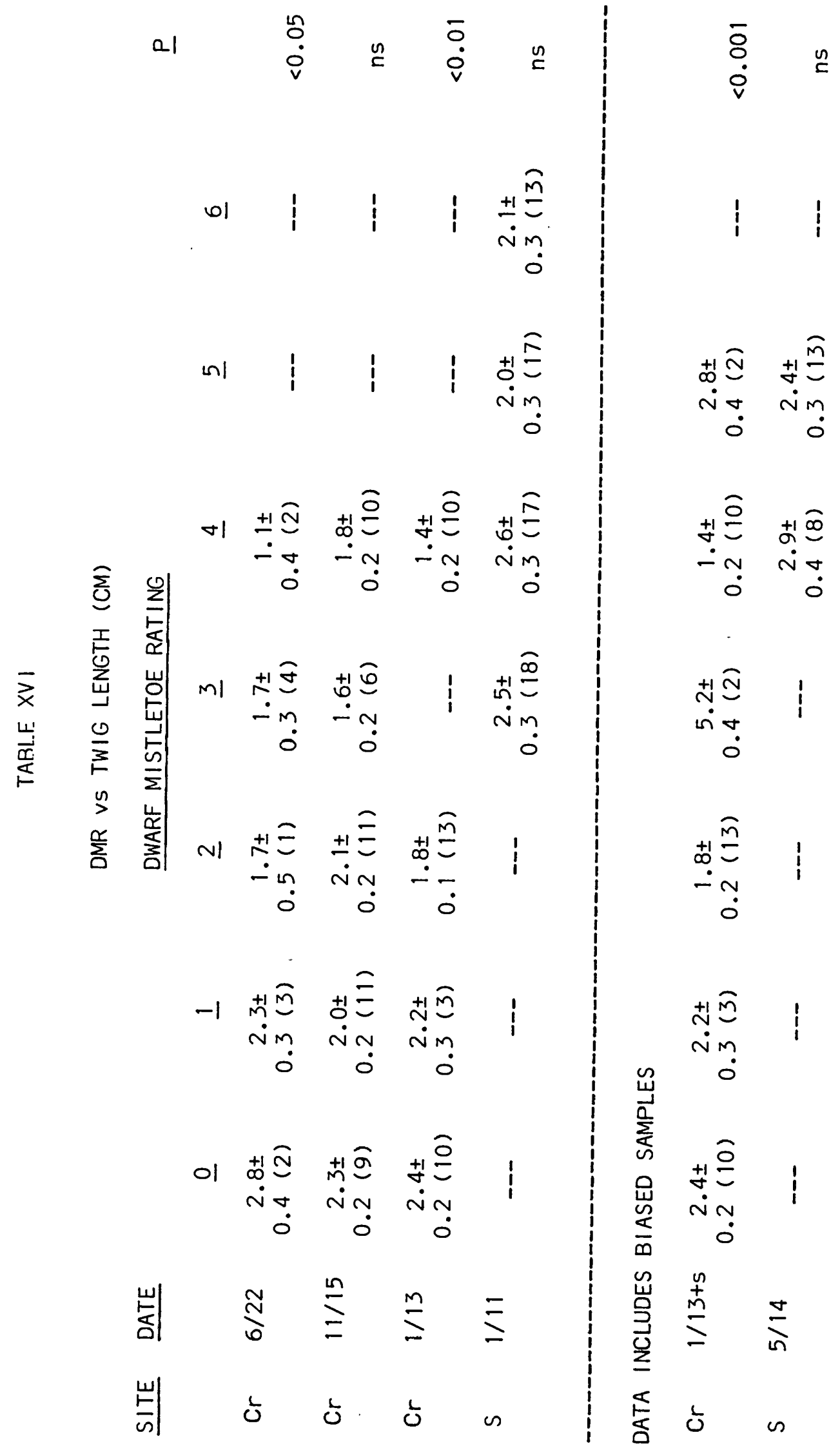




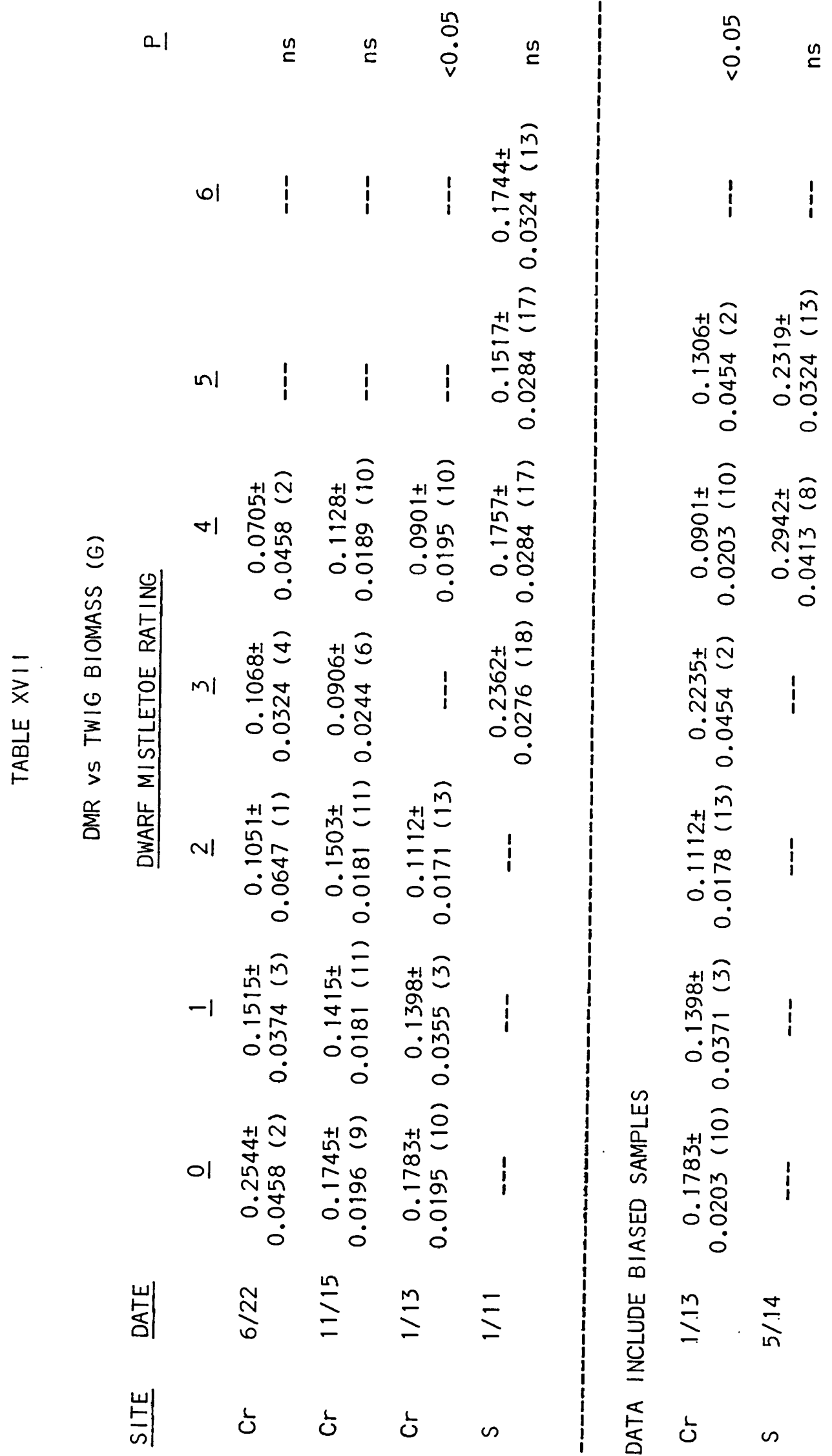




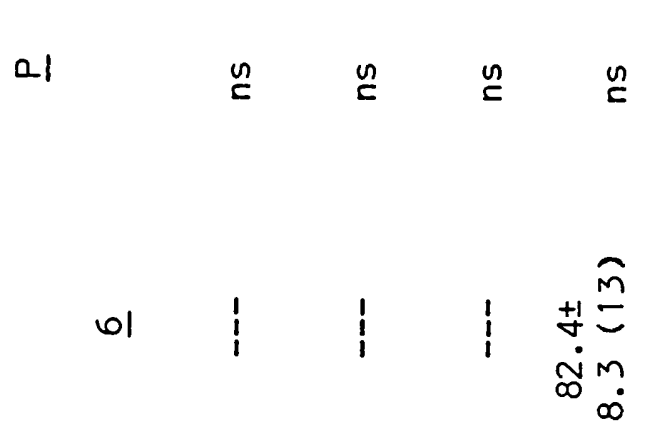

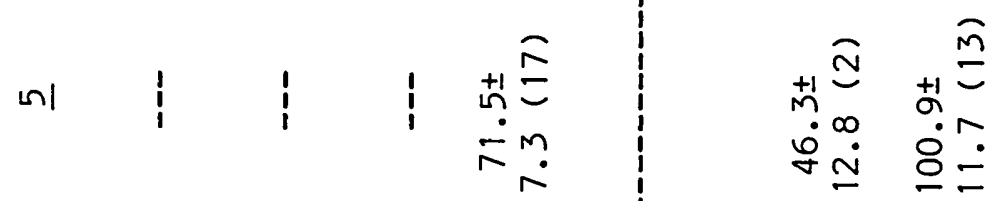

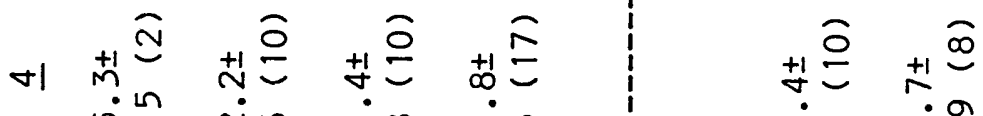

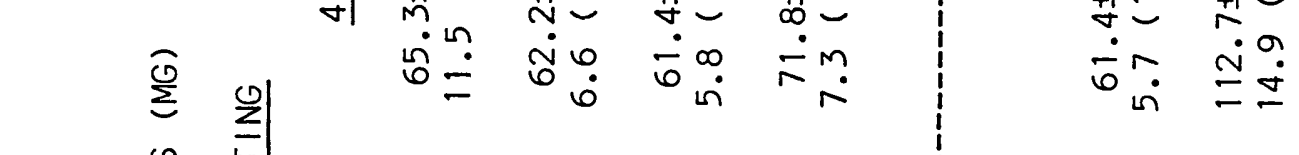

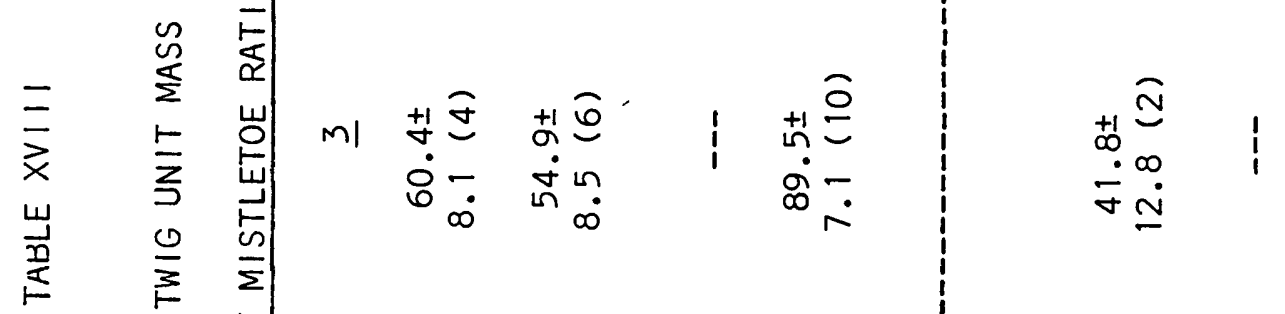

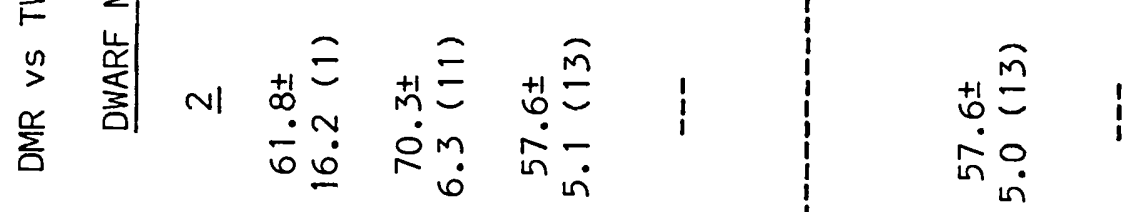

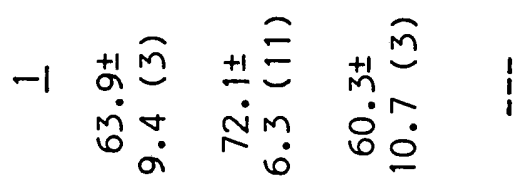

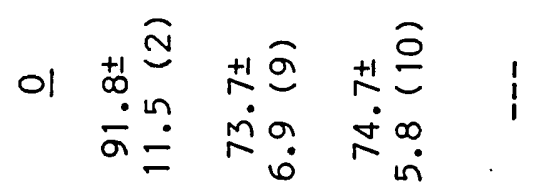

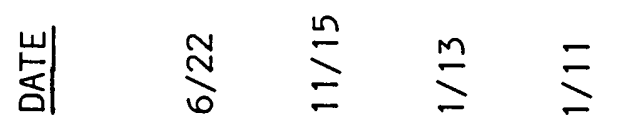

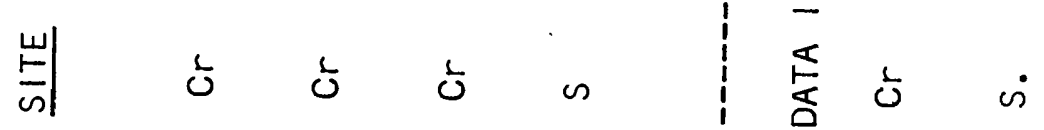


a) $\begin{array}{llll}* & * & & \\ \text { a } & \dot{0} & \dot{0} & \dot{0}\end{array}$

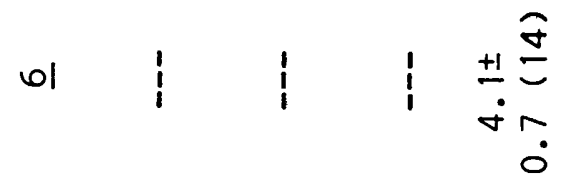

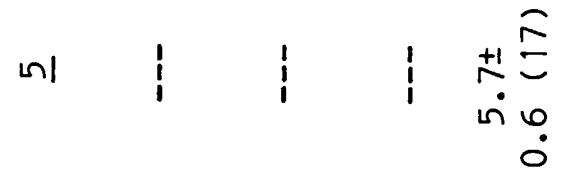

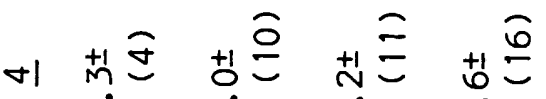

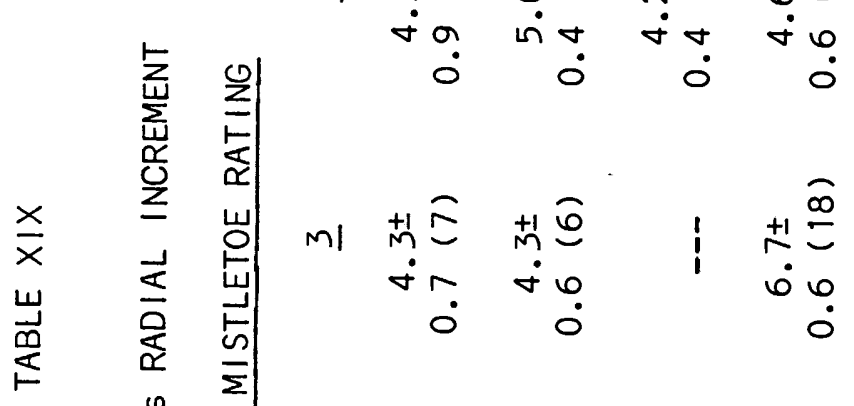

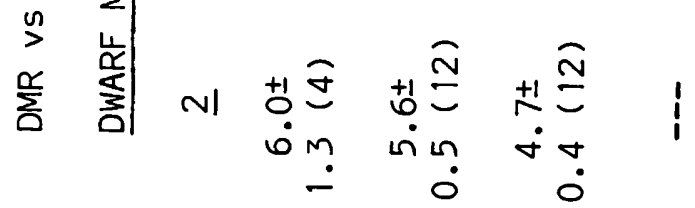

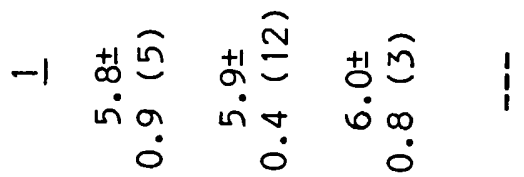

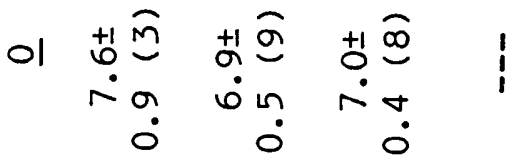

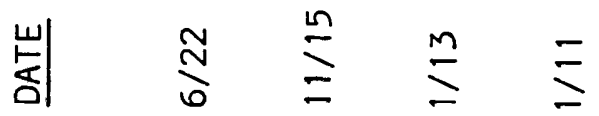

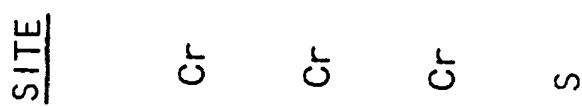




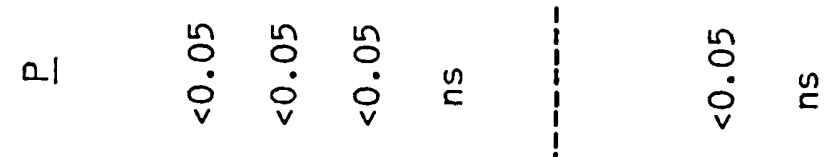

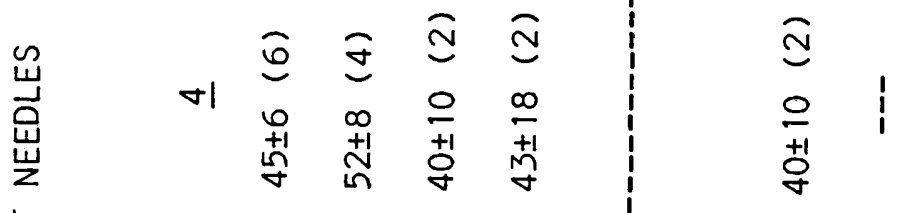

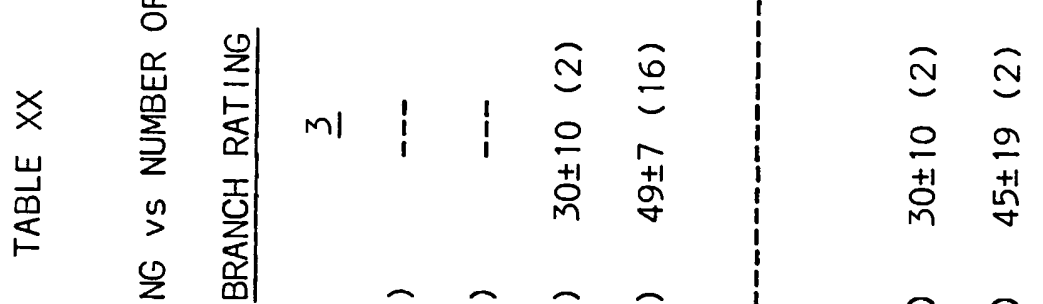

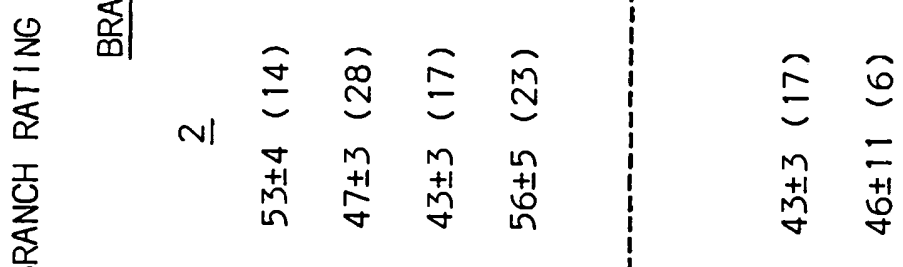

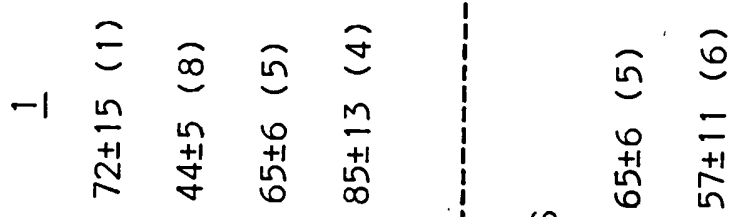

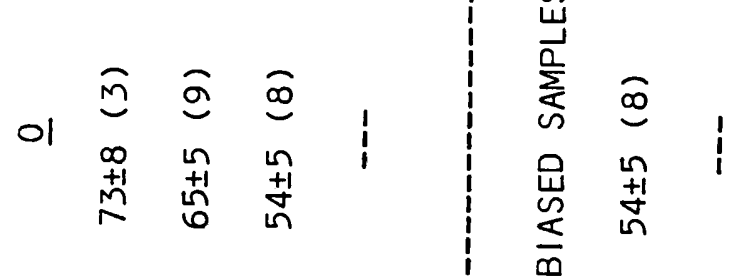

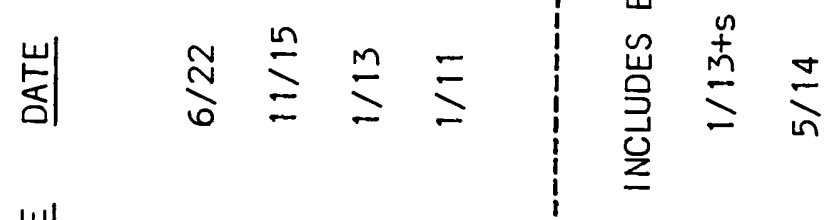

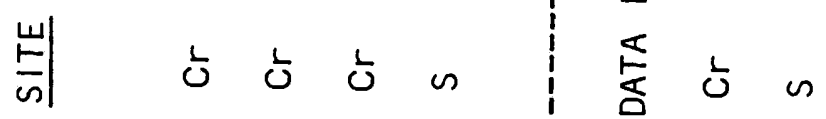




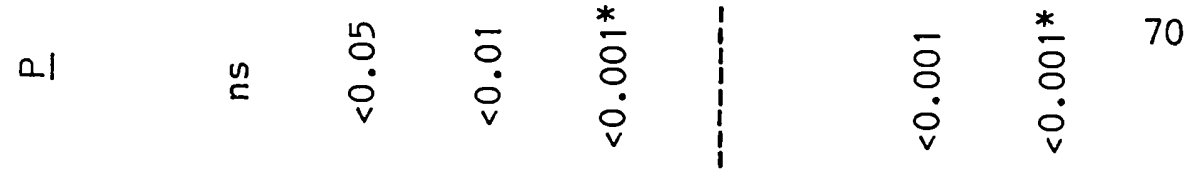

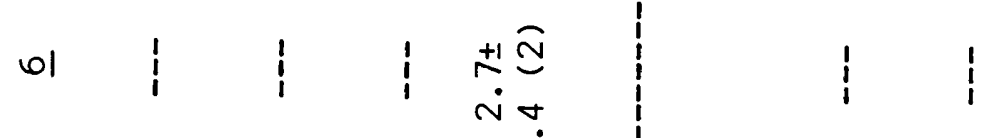

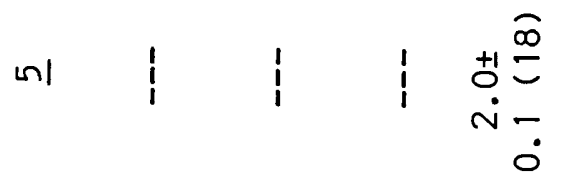

$$
\begin{aligned}
& \stackrel{+}{\sim} \pm \cong \\
& \text {-m } \\
& \text { 흘 }
\end{aligned}
$$

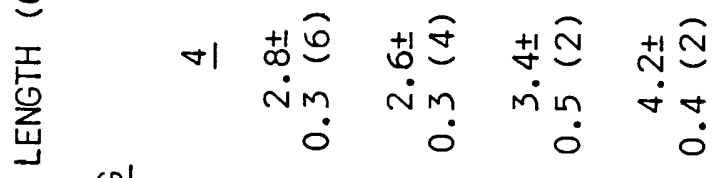

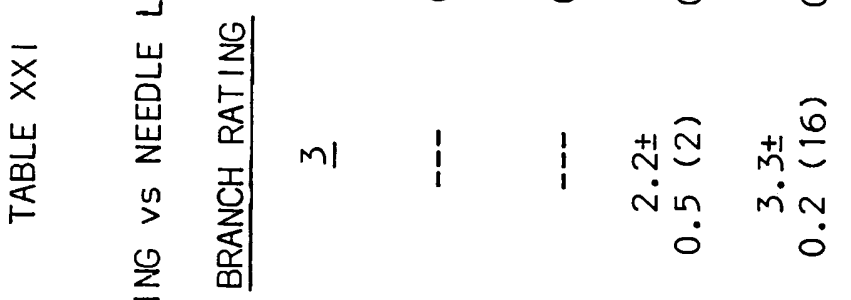

$$
\begin{aligned}
& \text { 旁 }
\end{aligned}
$$

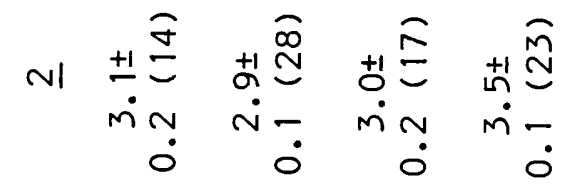

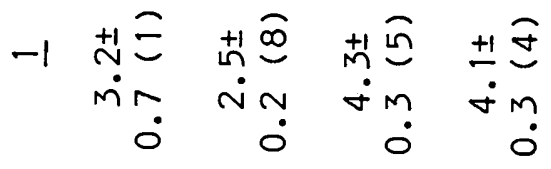

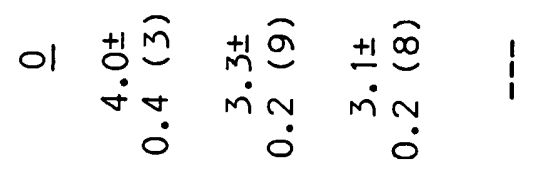

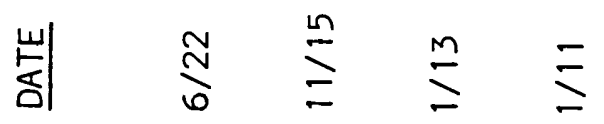

$$
\begin{aligned}
& \text { 厥 } \\
& \text { ò ò o }
\end{aligned}
$$

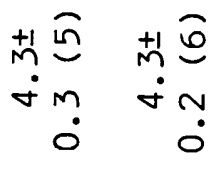

$$
\begin{aligned}
& \text { 艾可 } \\
& \begin{array}{c}
\dot{N} \text { in } \\
\dot{0}
\end{array}
\end{aligned}
$$

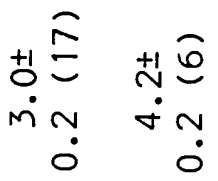

$$
\begin{aligned}
& \sum_{\frac{1}{4}}^{n} \\
& \begin{array}{c}
+\underset{y}{+1} \\
\dot{0}
\end{array} \\
& \text { 岕 } \frac{1}{\infty} \text { m }
\end{aligned}
$$

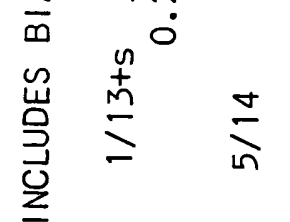

$$
\begin{aligned}
& \text { 爱战的 }
\end{aligned}
$$




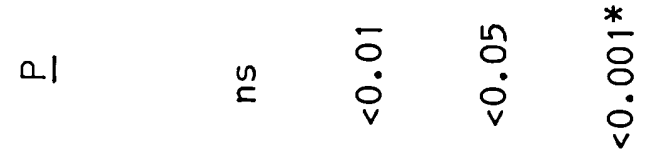

$$
\begin{aligned}
& \begin{array}{lll}
i & 0 \\
i & 0 & \\
1 & & \\
1 & 1 & 1
\end{array} \\
& \begin{array}{lll}
1 & \stackrel{+1}{N} \sqrt{ \pm} \\
\frac{N}{N} \frac{0}{N}
\end{array} \\
& \text { نั }
\end{aligned}
$$

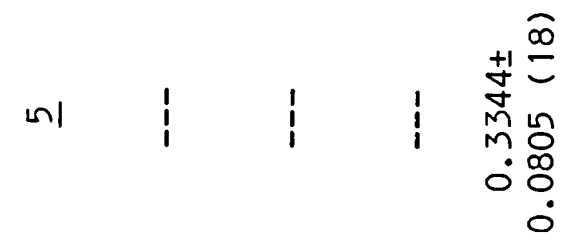

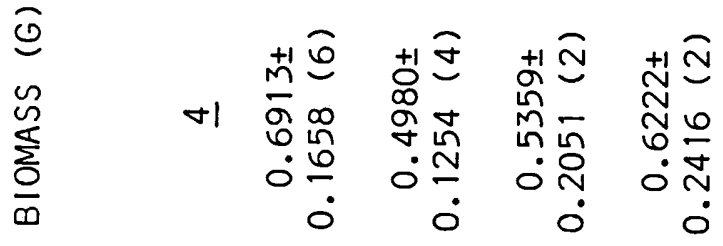

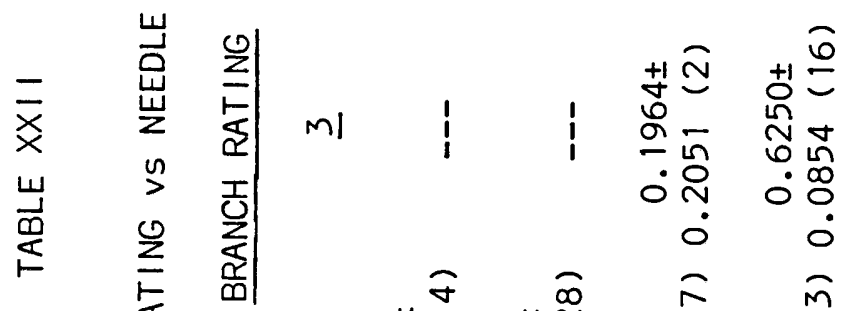

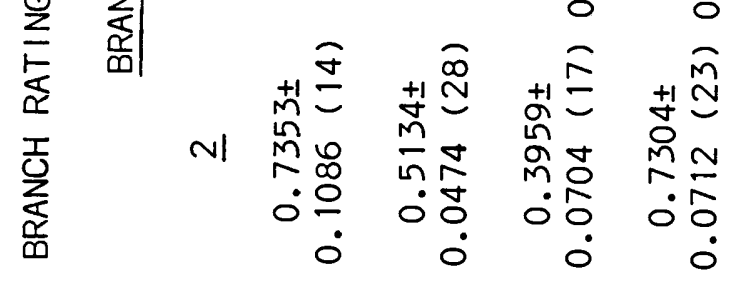

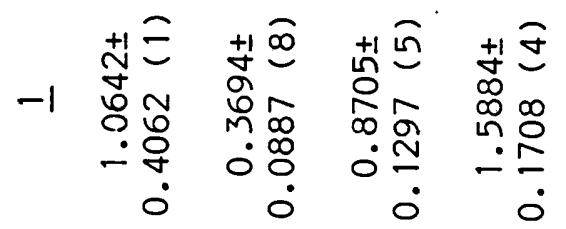

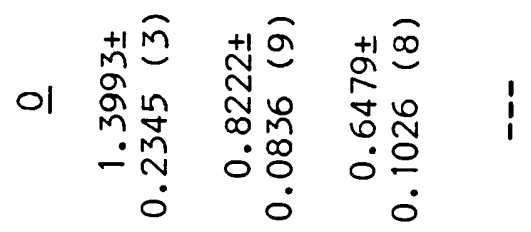

$$
\begin{aligned}
& \text { 嵌 } \\
& \text { 崩就方 }
\end{aligned}
$$

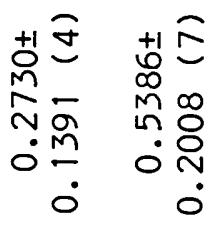

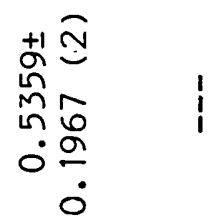

$$
\begin{aligned}
& \text { +ป ญ } \\
& \text { ดิ ลิ } \\
& \text { - } \frac{1}{-} \\
& \text { 0 } 0
\end{aligned}
$$

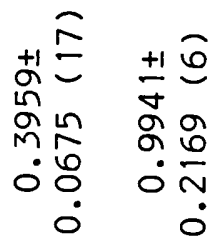

$$
\begin{aligned}
& \text { ㄴํำ } \\
& \text { 요 융요 } \\
& \dot{0} \underset{0}{\stackrel{N}{N}}
\end{aligned}
$$

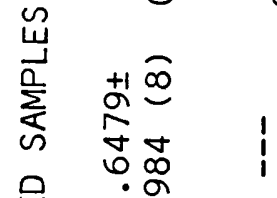

$$
\begin{aligned}
& \text { 岁 }
\end{aligned}
$$

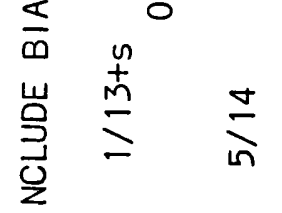

$$
\begin{aligned}
& \stackrel{5}{\mathbb{E}} \text { o }
\end{aligned}
$$




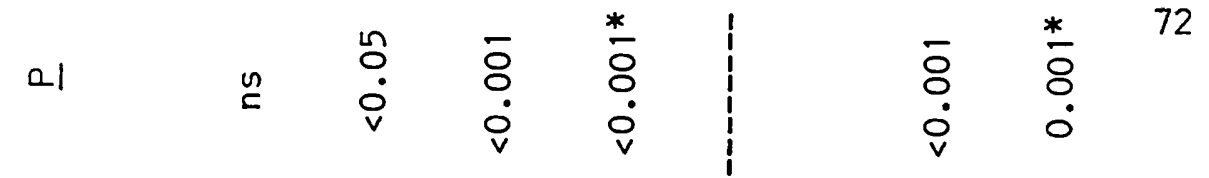

$$
\begin{aligned}
& \text { ol } \\
& \text { i } \quad \stackrel{+1}{i} \underset{\sim}{\stackrel{N}{N}} \\
& \text { 이 } \\
& i \quad \begin{aligned}
+\infty & \infty \\
i & \infty \\
\infty & \infty
\end{aligned} \\
& \stackrel{O}{\Sigma}
\end{aligned}
$$

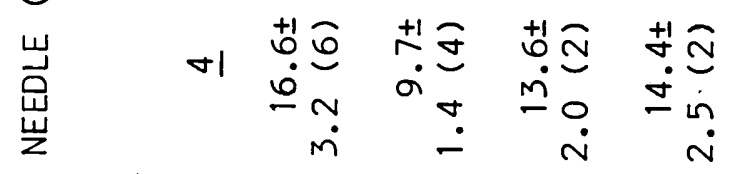

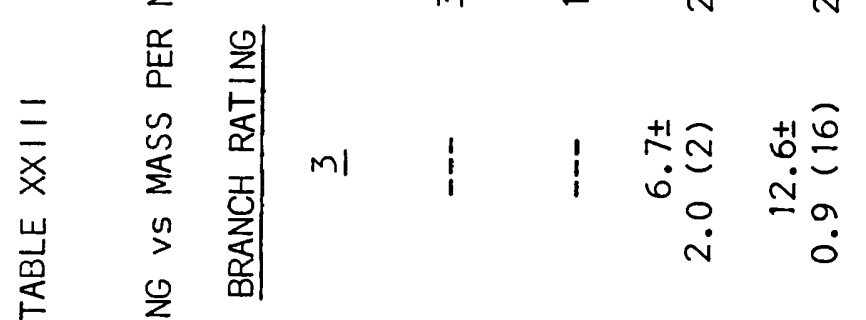

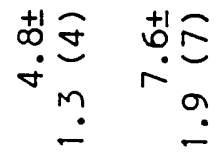

$$
\begin{aligned}
& \begin{array}{l}
+ 1 \longdiv { Y } \\
\text { ma }
\end{array}
\end{aligned}
$$

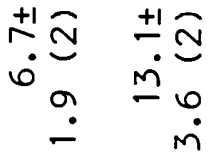

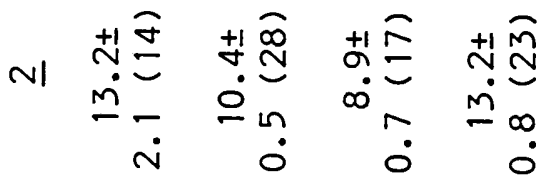

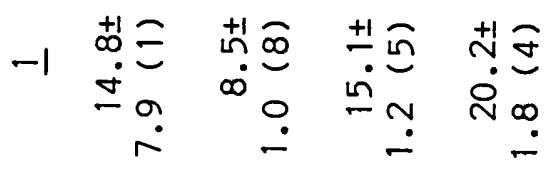

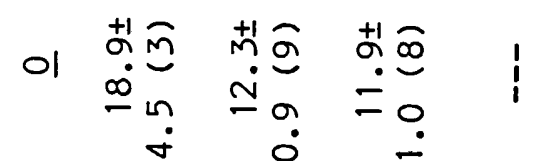

$$
\begin{aligned}
& \text { แั山ิำ } \\
& \frac{\omega}{\infty} \\
& \frac{1}{0} \quad \frac{1}{0} \quad n
\end{aligned}
$$

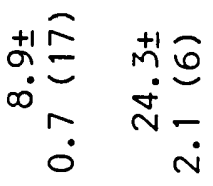

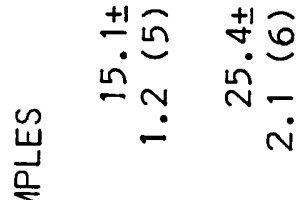

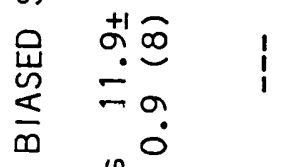

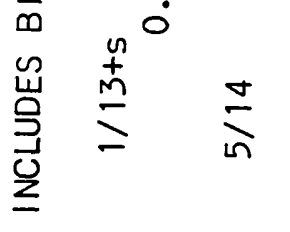

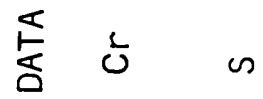




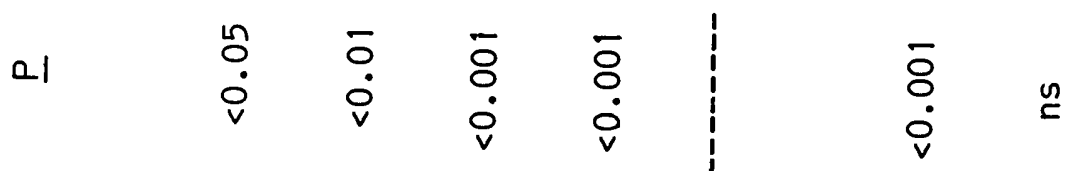

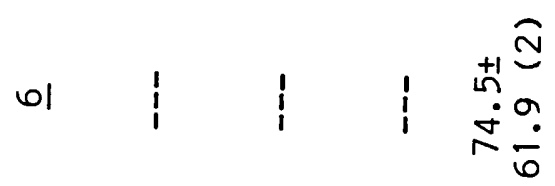

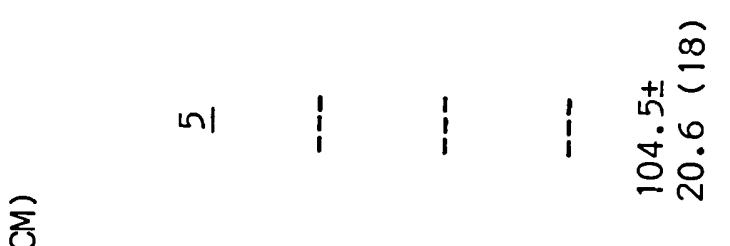

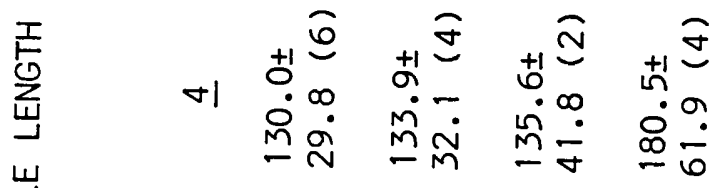

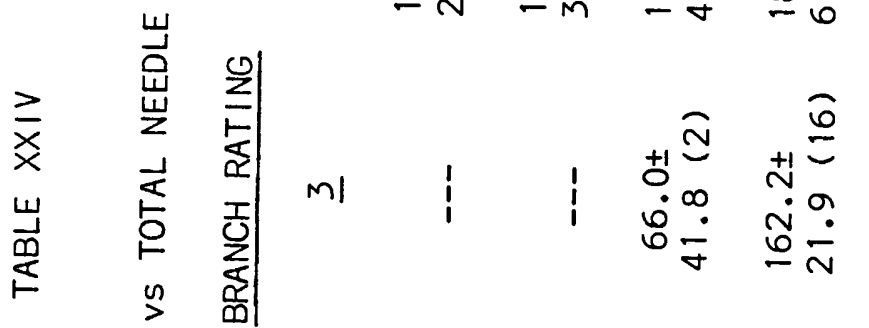

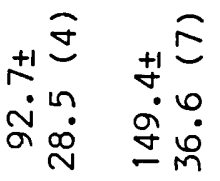

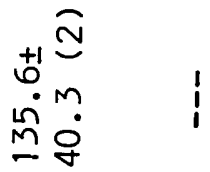

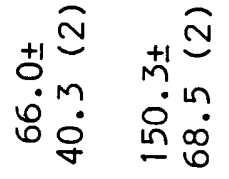

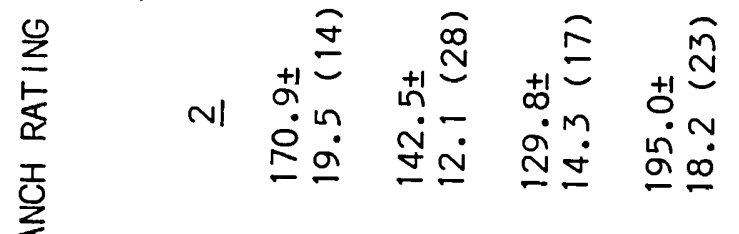

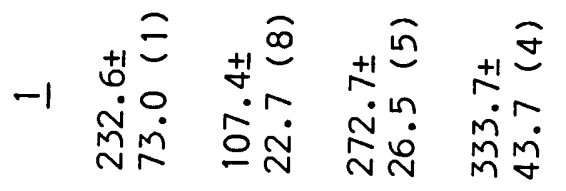

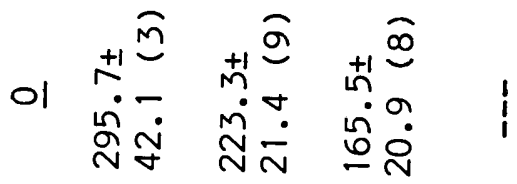

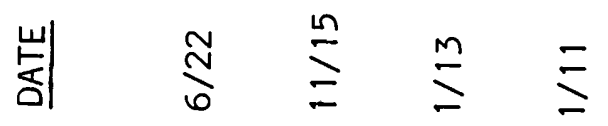

$$
\begin{aligned}
& \text { 嵌 c̀ do d o }
\end{aligned}
$$

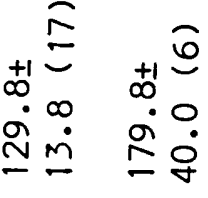

$$
\begin{aligned}
& +1 \bar{a}+\overline{0}
\end{aligned}
$$

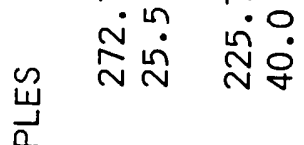

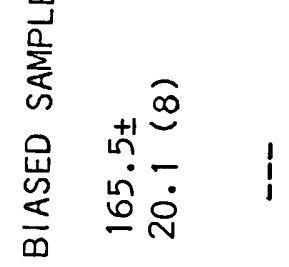

$$
\begin{aligned}
& \text { 晜 } \\
& \text { 余方 }
\end{aligned}
$$




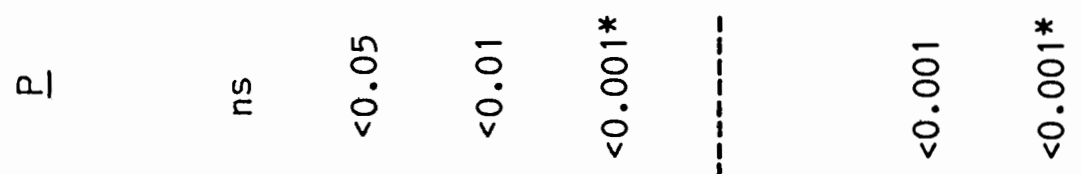

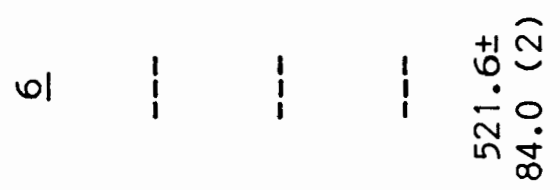

$$
\begin{aligned}
& \text { nl } \quad 1 \quad 1 \quad 1 \quad+10 \\
& \text { 迥品 } \\
& \stackrel{+}{\sum_{U}^{N}} \\
& \text { 崖 बा }
\end{aligned}
$$

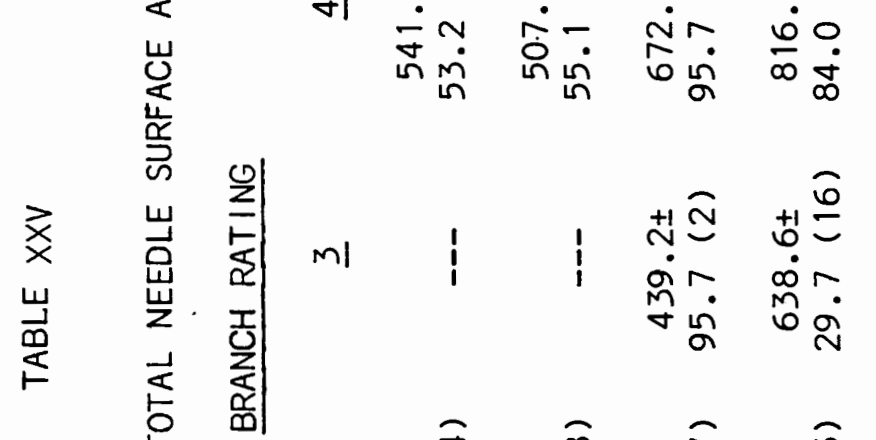

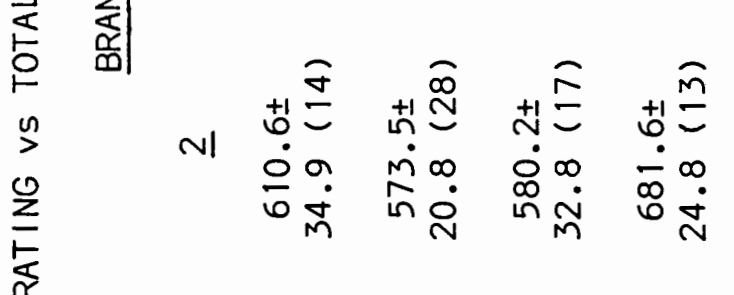

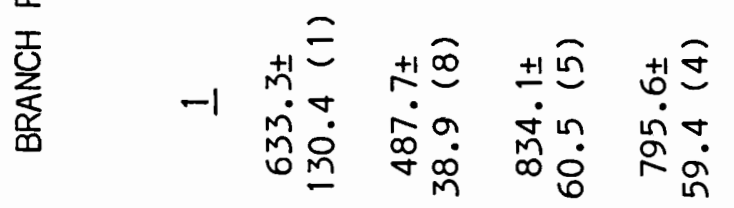

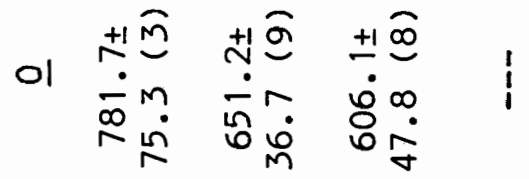

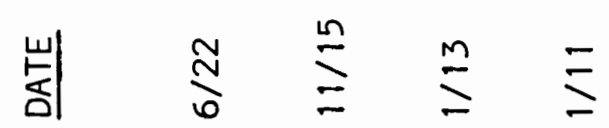

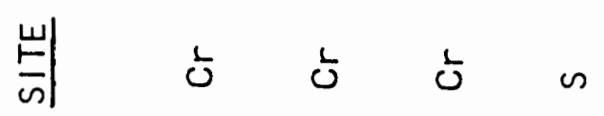

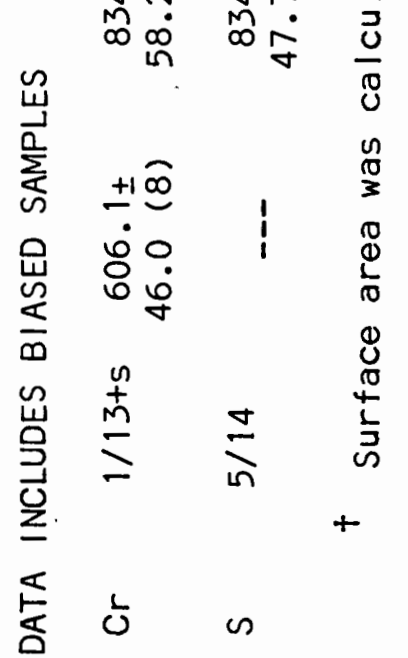

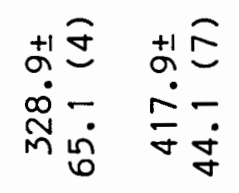

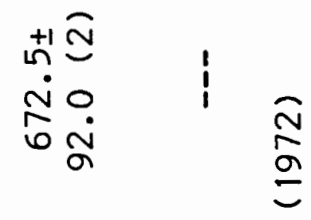

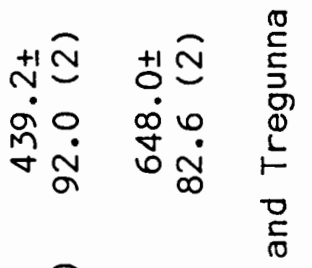

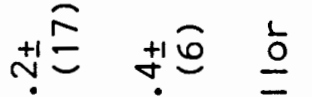

$$
\begin{aligned}
& \text { }
\end{aligned}
$$

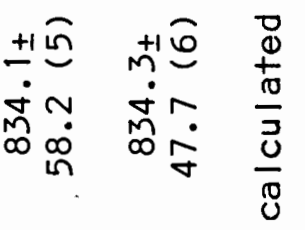




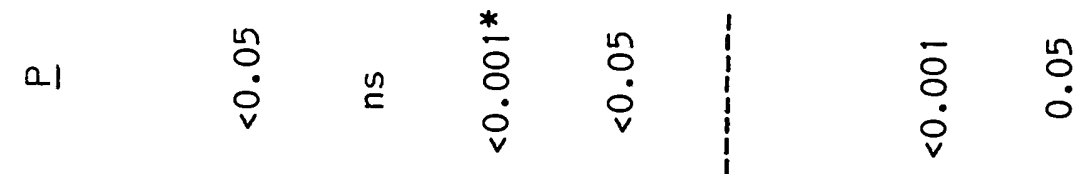

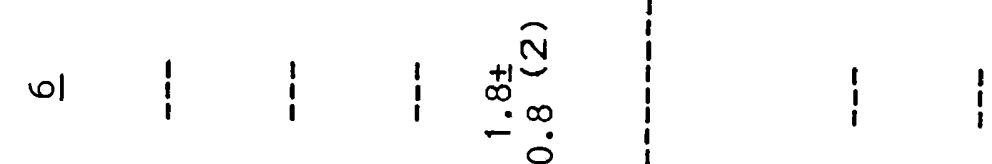

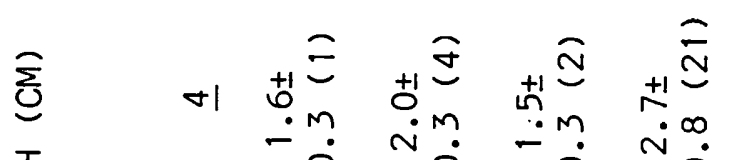

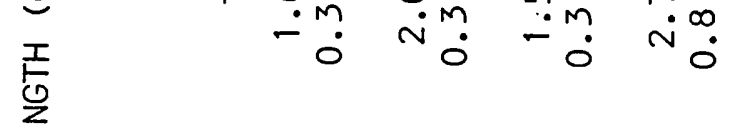

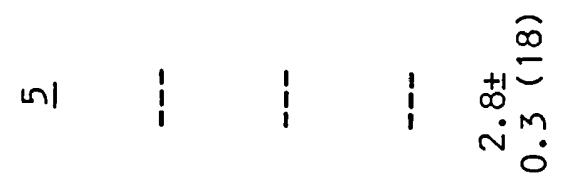

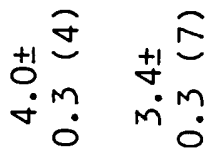

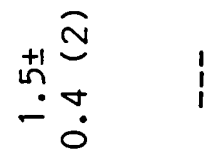

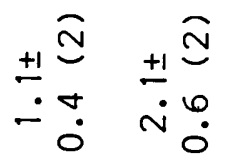

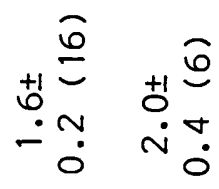

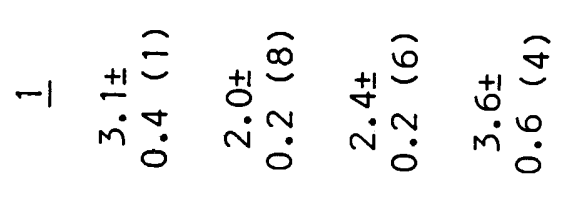

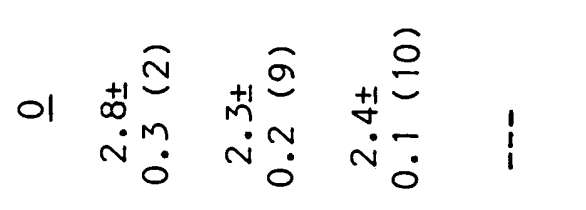

$$
\begin{aligned}
& \text { 容 } \quad \stackrel{n}{\Xi} \stackrel{m}{\equiv} \equiv
\end{aligned}
$$

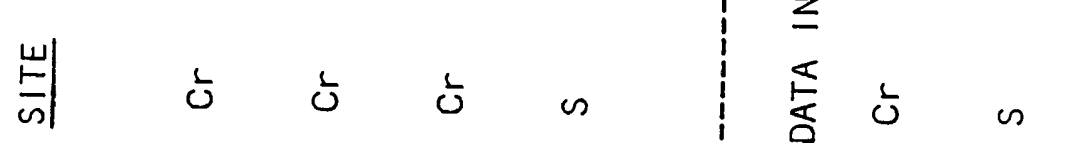

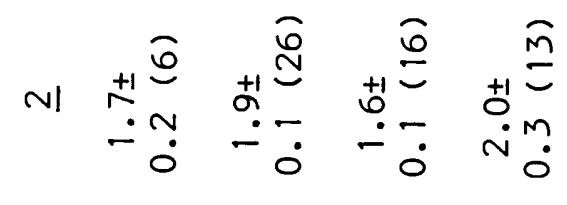

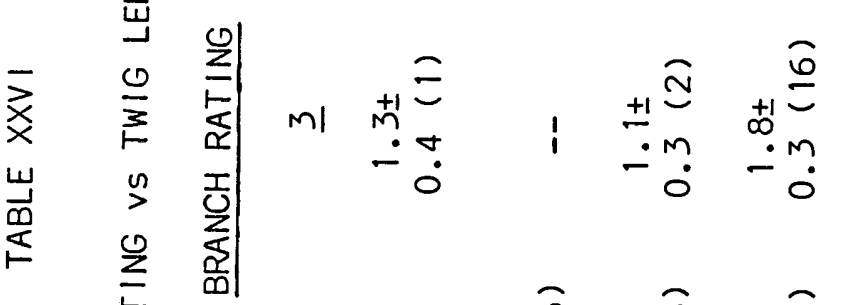

$$
\begin{aligned}
& \text { 要 }
\end{aligned}
$$




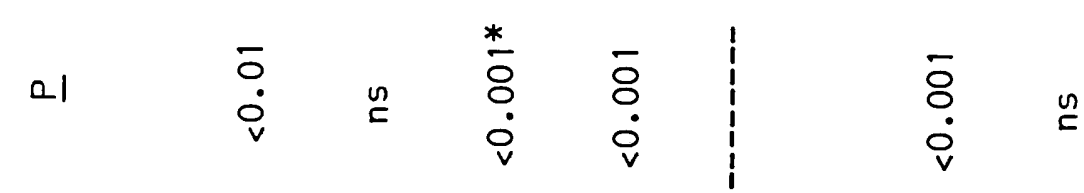

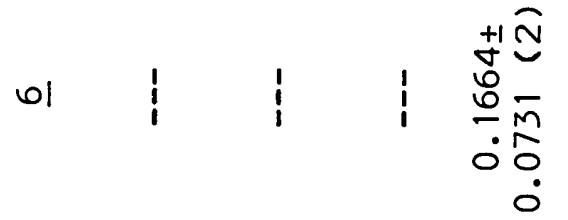

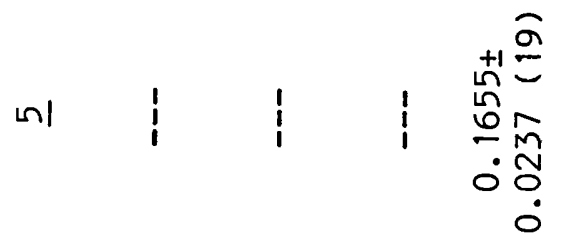

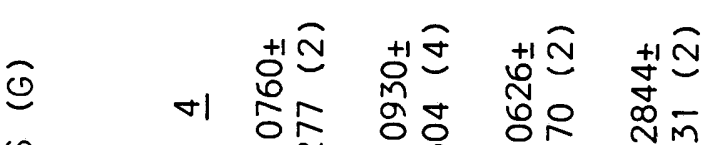

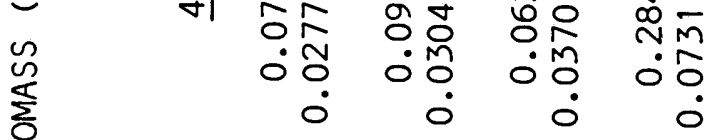

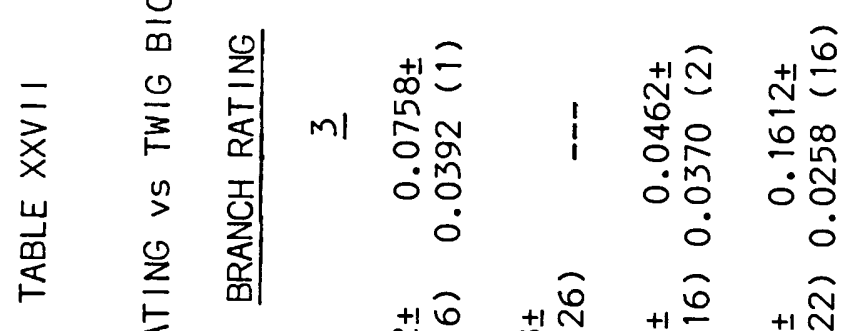

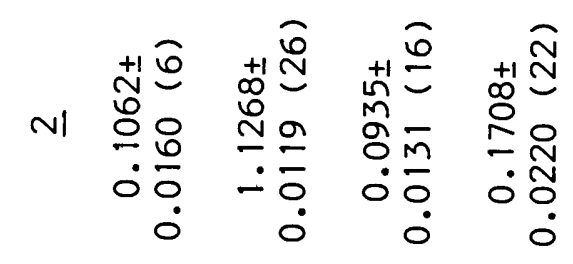

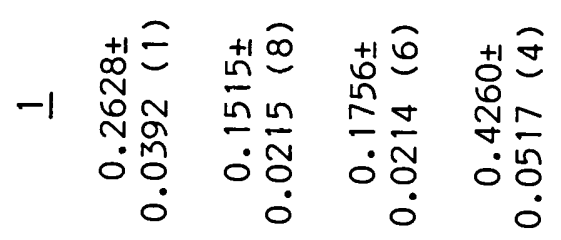

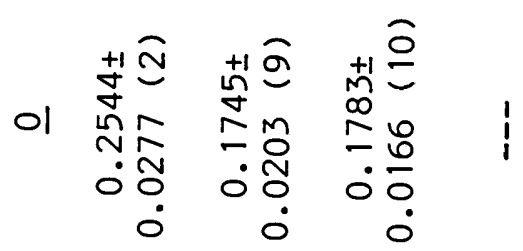

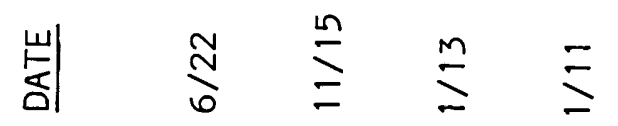

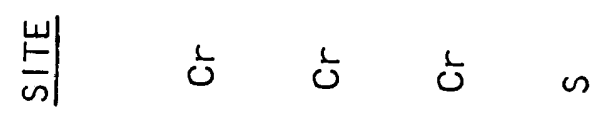

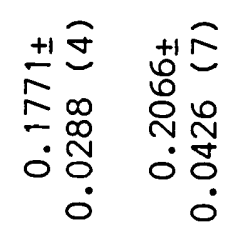

$$
\begin{aligned}
& \begin{array}{l}
\stackrel{+1}{\cong} \\
\text { ஸे } \\
0 \\
0 \\
0 \\
0 \\
0
\end{array}
\end{aligned}
$$

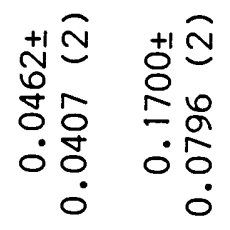

$$
\begin{aligned}
& \stackrel{+1}{\stackrel{0}{2}}+\stackrel{+1}{\underline{m}} \\
& \text { 원ำ } \\
& \text { ०० } \\
& \text { +10 } \\
& \text { 뜬 } \\
& \begin{array}{r}
0 \\
0
\end{array}
\end{aligned}
$$

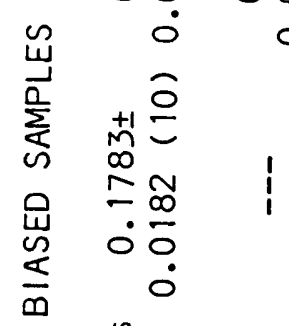

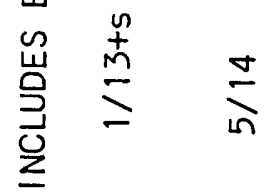

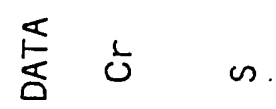




$$
\begin{aligned}
& \text {-1 n n n e n } \begin{array}{l}
\bar{O} \\
\dot{0}
\end{array}
\end{aligned}
$$

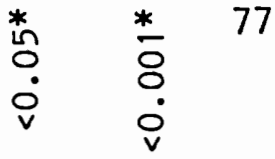

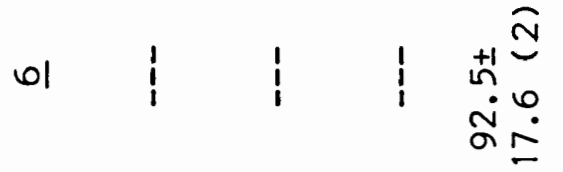

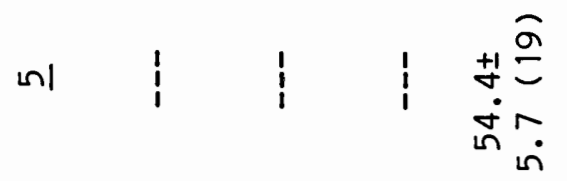

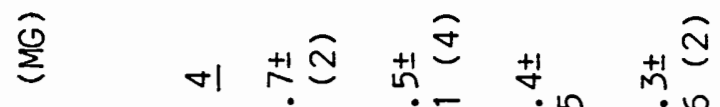

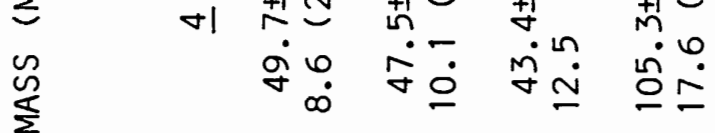

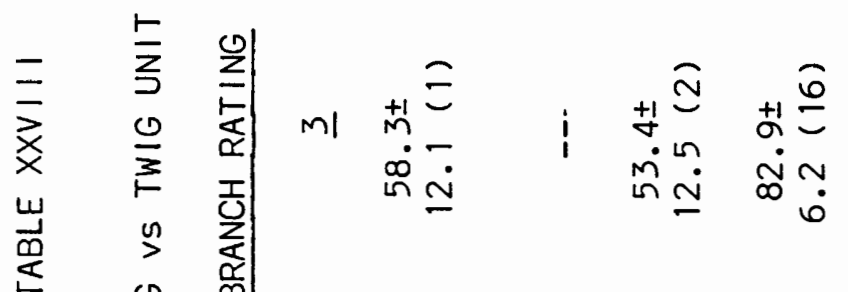

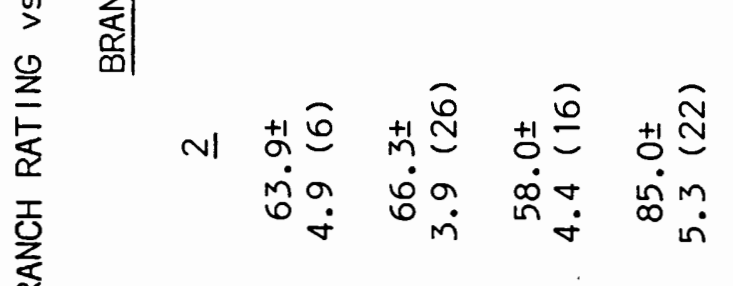

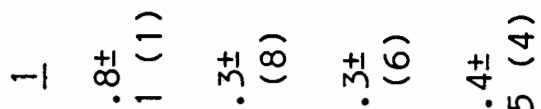

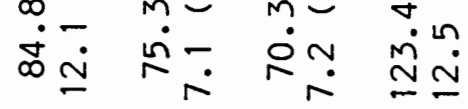

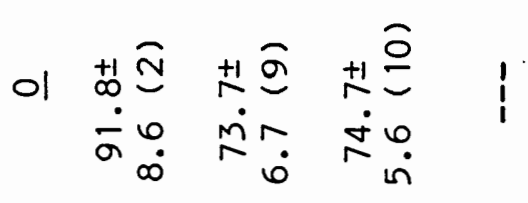

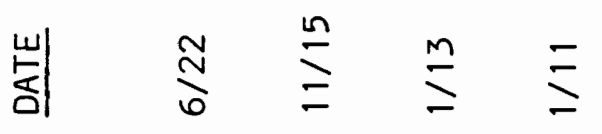

$$
\begin{aligned}
& \frac{w}{\omega} \\
& \text { ¿̀̃ ò o o }
\end{aligned}
$$

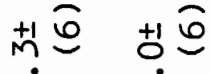

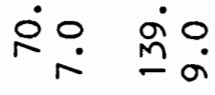

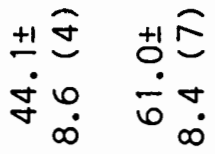

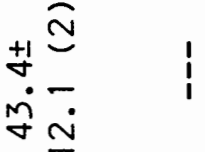

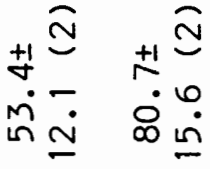

$$
\begin{aligned}
& \text { +을 } \\
& \text { in: } \frac{-1}{\circ} \dot{0}
\end{aligned}
$$

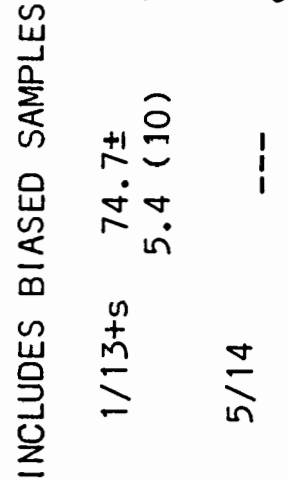

$$
\begin{aligned}
& \text { 总喜点 } \\
& \text { 余势 o }
\end{aligned}
$$




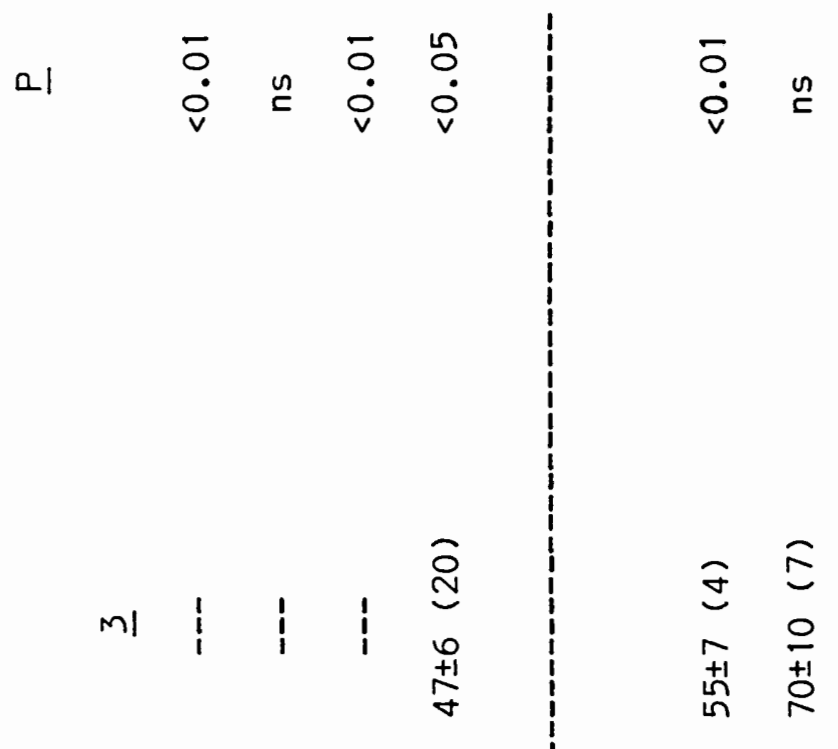

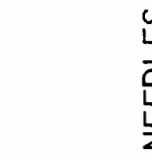

岂

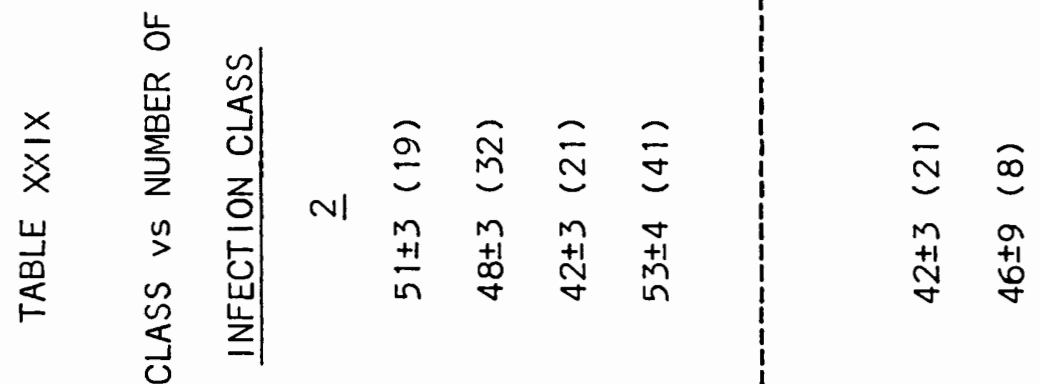

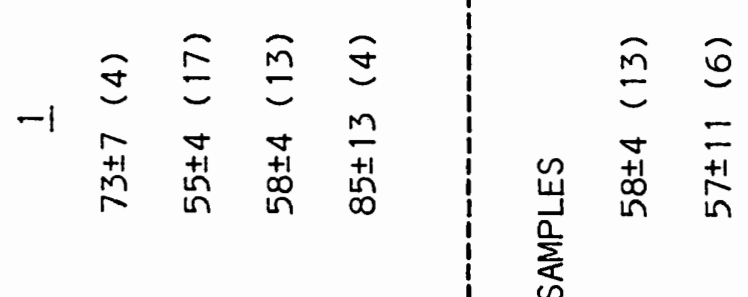

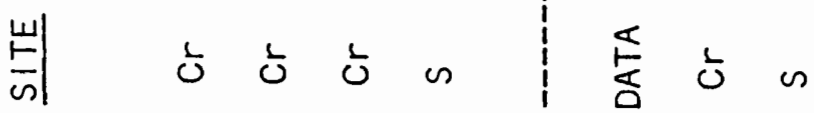




$$
\begin{aligned}
& \text { 4 } \\
& \text { 产 } \\
& \text { mi i i } \quad \text { i } \quad \text { i } \quad \text { i } \\
& \text { 跣 } \\
& \text { 焉 }
\end{aligned}
$$

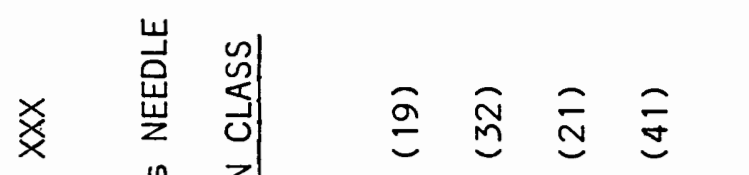

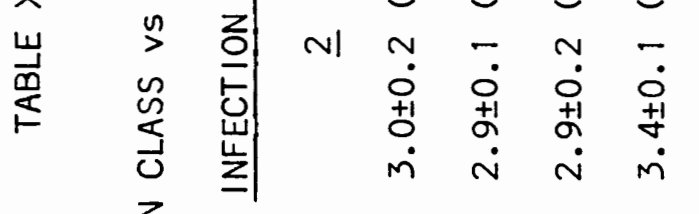

$$
\begin{aligned}
& \text { స్ } \\
& \sim N \\
& \begin{array}{ll}
\dot{0} & 0 \\
\dot{0} & \dot{0} \\
\dot{0} & \dot{1}
\end{array}
\end{aligned}
$$

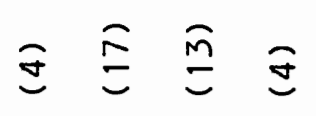

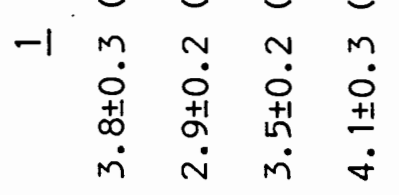

$$
\begin{aligned}
& \stackrel{m}{=}
\end{aligned}
$$

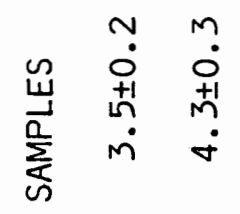

$$
\begin{aligned}
& \text { 岂 }
\end{aligned}
$$

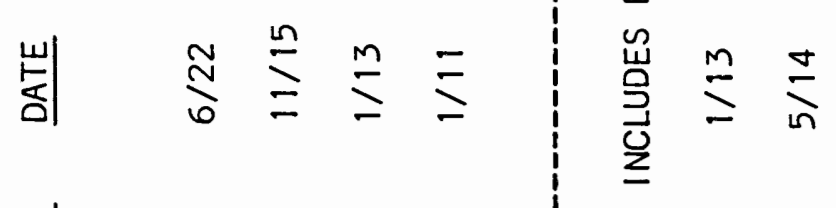

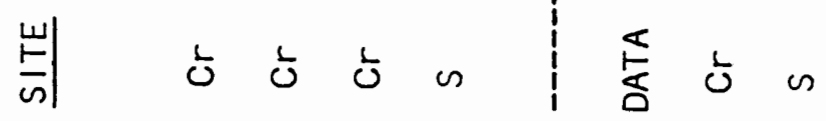




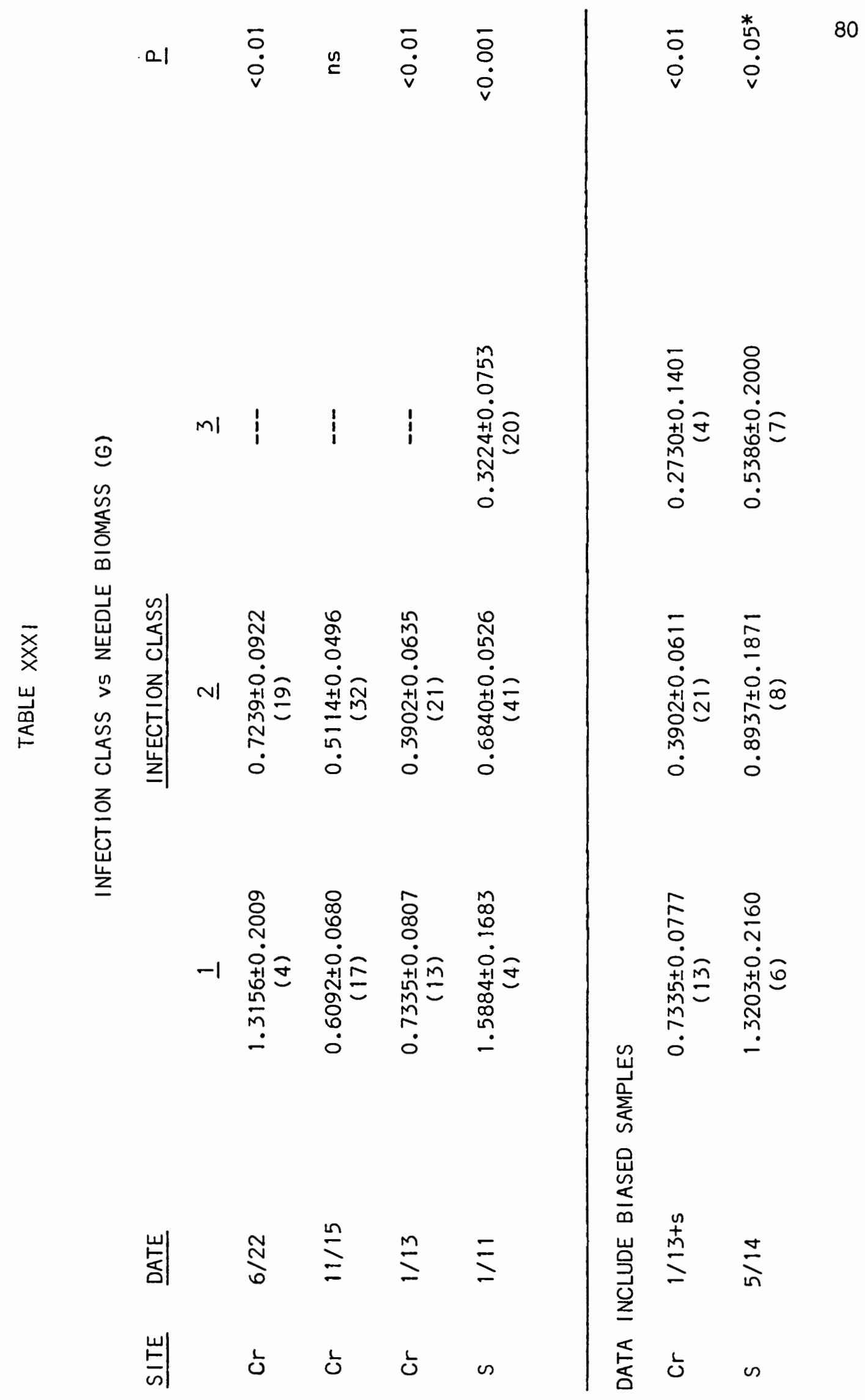




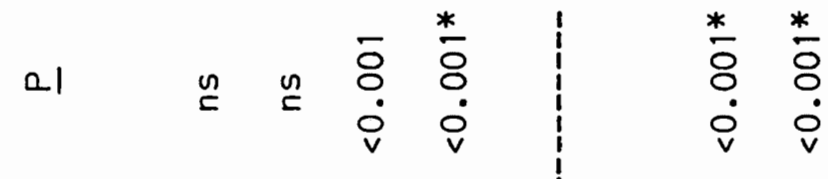

$$
\begin{aligned}
& \widehat{O} \\
& \text { o } 1 \text { i }
\end{aligned}
$$

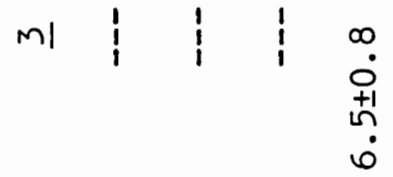

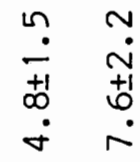

$$
\begin{aligned}
& \text { 峞 }
\end{aligned}
$$

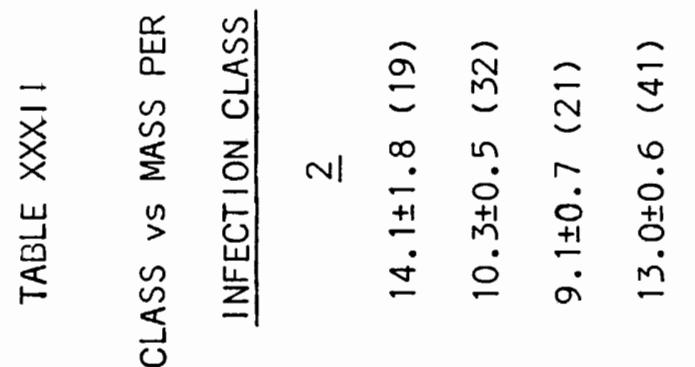

$$
\begin{aligned}
& \begin{array}{l}
\text { 으 } \\
\text { 㫐 } \\
\text { 는 }
\end{array}
\end{aligned}
$$

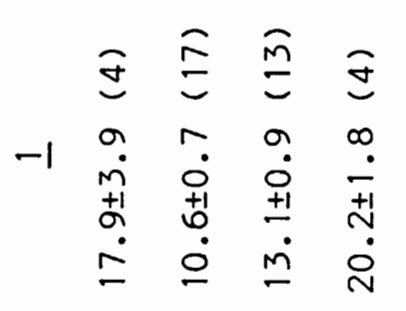

$$
\begin{aligned}
& \begin{array}{cc}
\check{\Xi} & \infty \\
\check{0} & \dot{N} \\
\dot{+1} & +1 \\
\dot{\sigma} & \bar{N}
\end{array} \\
& \underline{m}
\end{aligned}
$$

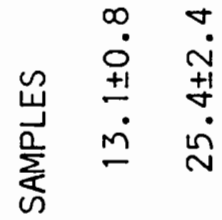

$$
\begin{aligned}
& \text { 는 } \\
& \text { 产 }
\end{aligned}
$$

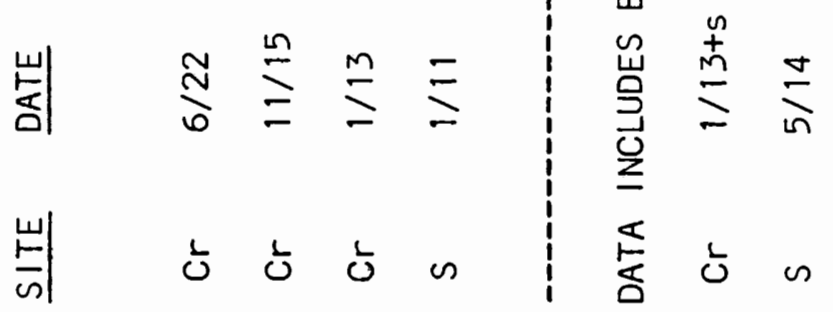




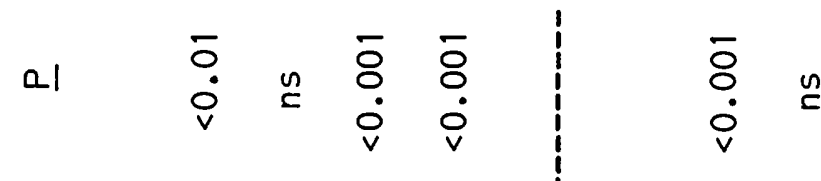

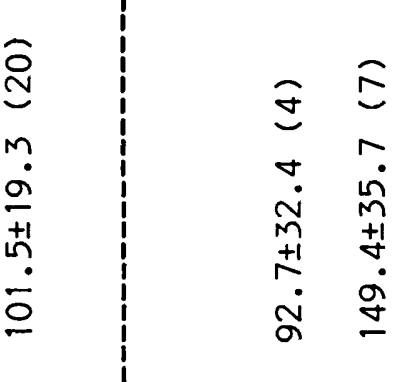

$$
\begin{aligned}
& \text { 志 } \\
& m 1: 1 \quad \frac{m}{\dot{a}} \\
& \text { 侥 }
\end{aligned}
$$

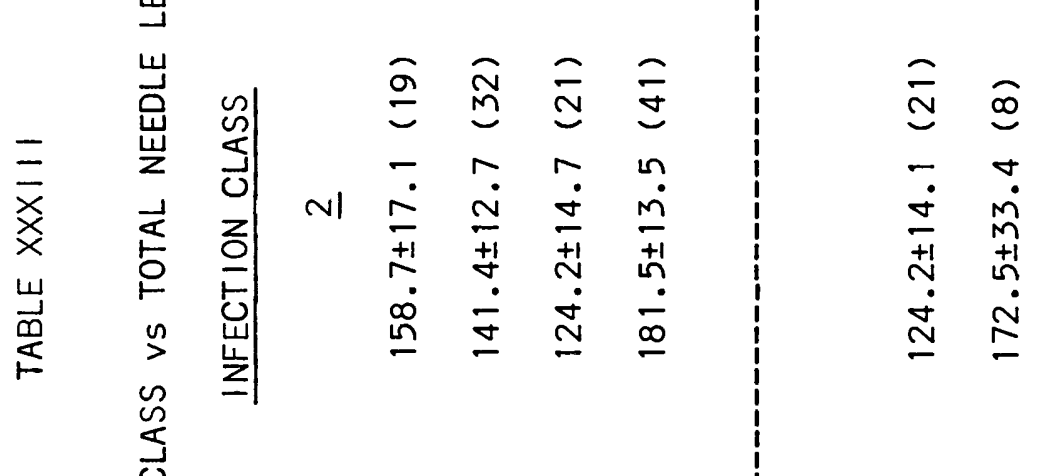

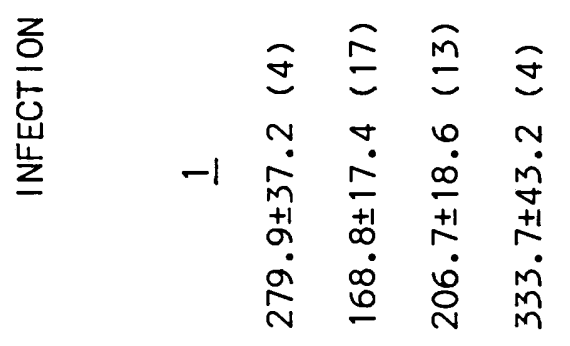

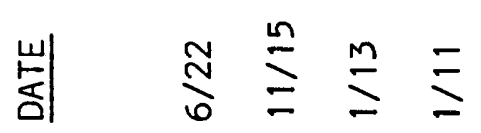

$$
\begin{aligned}
& \stackrel{m}{0} \\
& \stackrel{0}{\infty} \quad \infty \\
& \stackrel{\infty}{N} \stackrel{m}{N} \\
& \text { 峁 } \\
& \text { 岕 }
\end{aligned}
$$

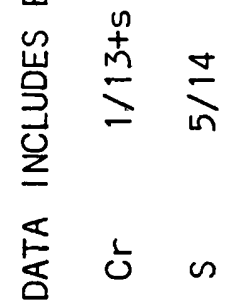




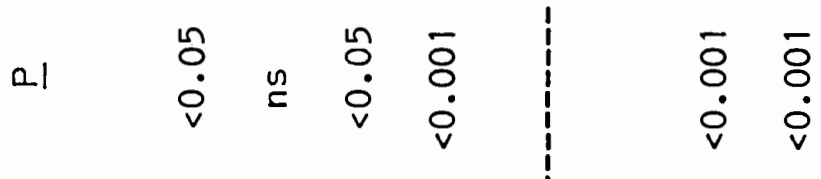

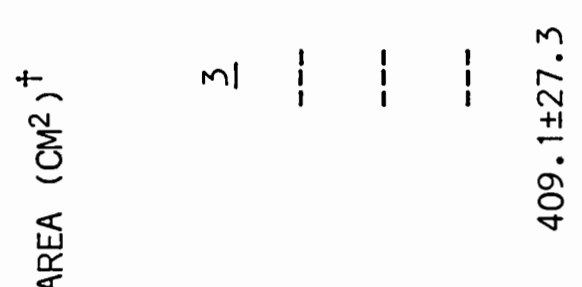

$$
\begin{aligned}
& \Xi \approx
\end{aligned}
$$

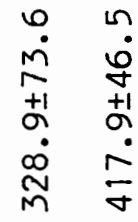

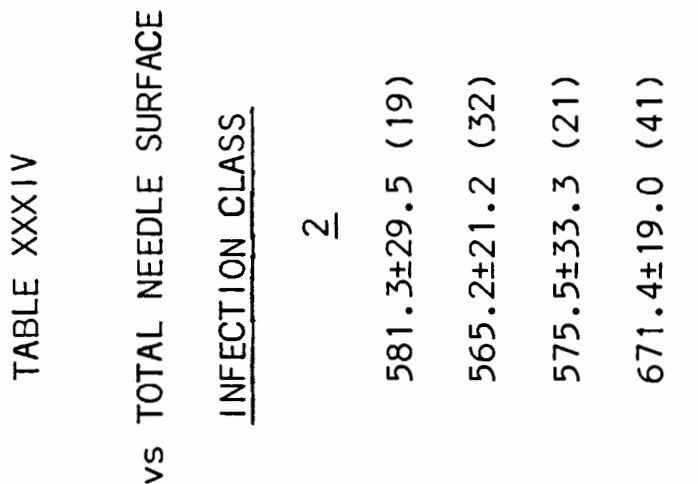

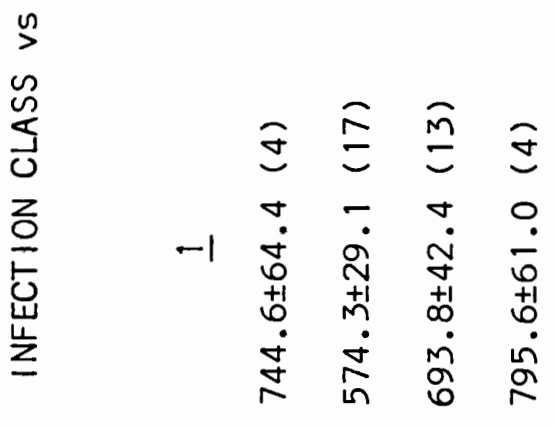

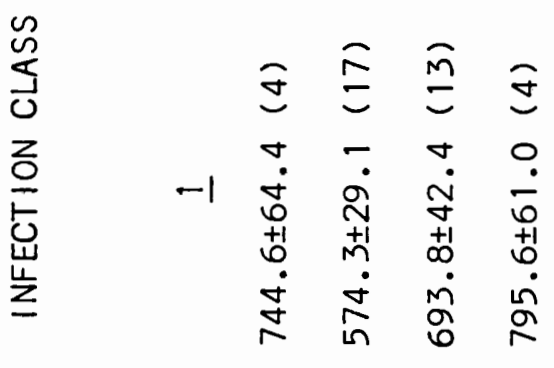

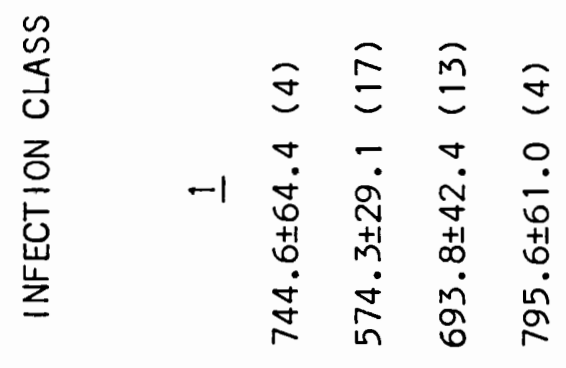

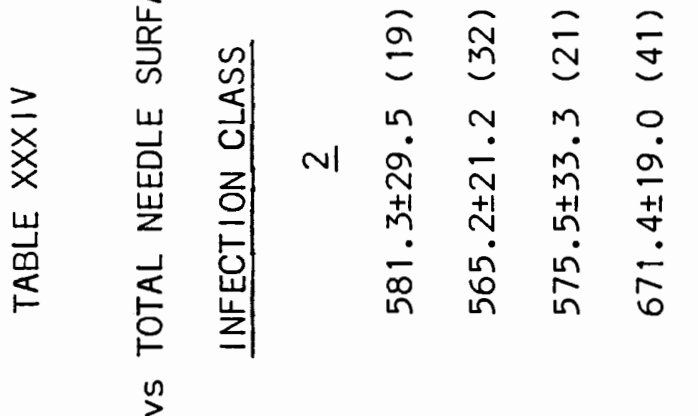

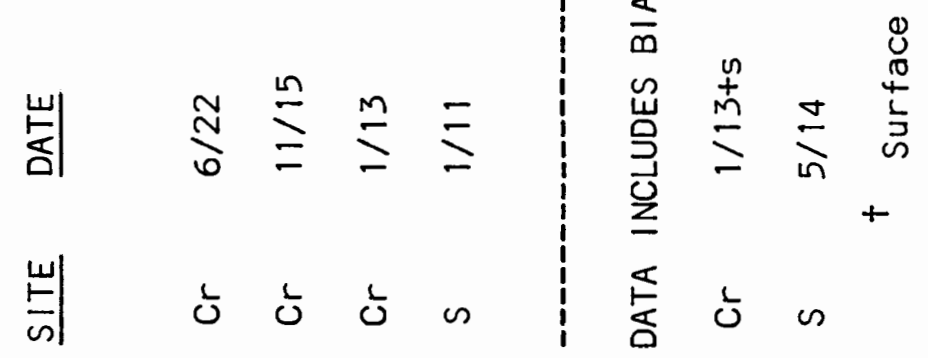

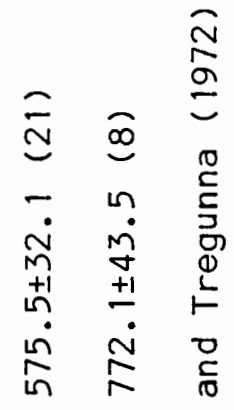

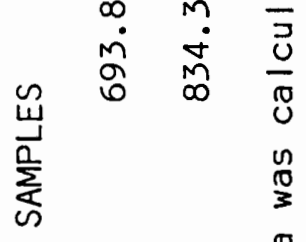

$$
\begin{aligned}
& \begin{array}{l}
\frac{1}{0} \\
\frac{0}{2} \\
\frac{1}{2} \\
\frac{1}{4}
\end{array}
\end{aligned}
$$

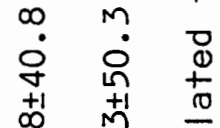

$$
\begin{aligned}
& \text { 岃 } \\
& \frac{1}{0}
\end{aligned}
$$




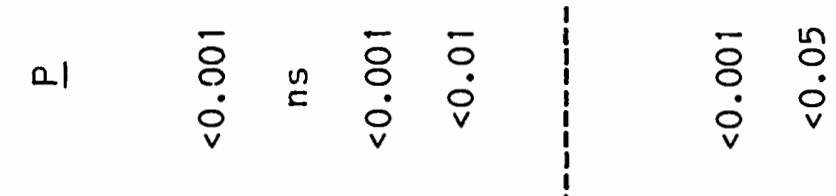

$$
\begin{aligned}
& \begin{array}{l}
\sum_{U}^{I} \\
\text { I } \\
\sum_{U}^{U}
\end{array}
\end{aligned}
$$

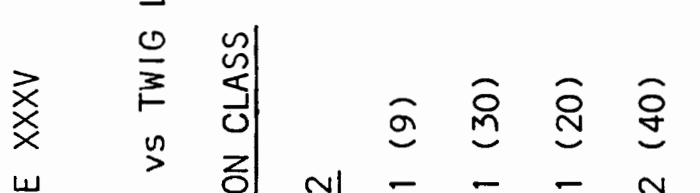

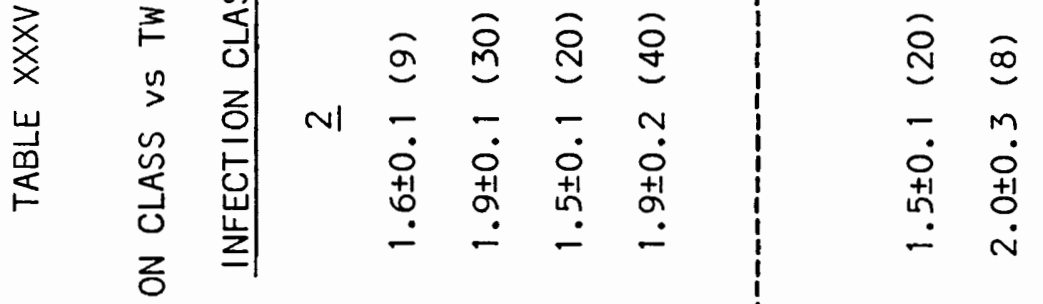

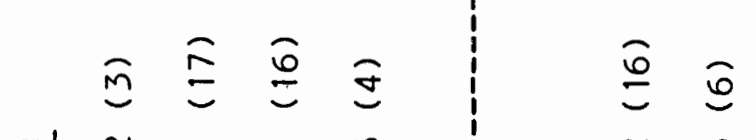

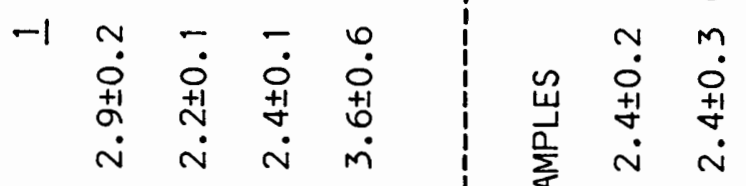

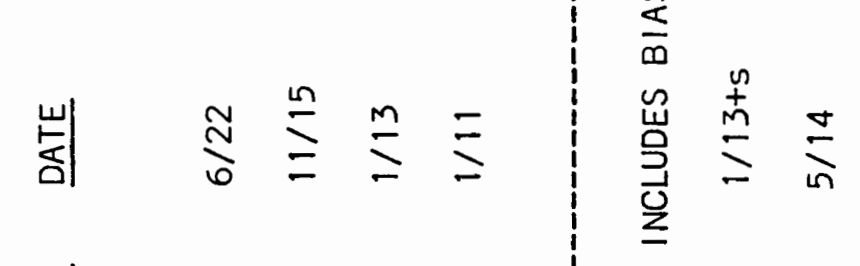

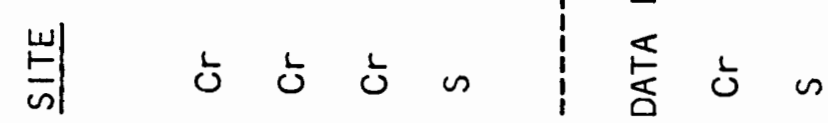




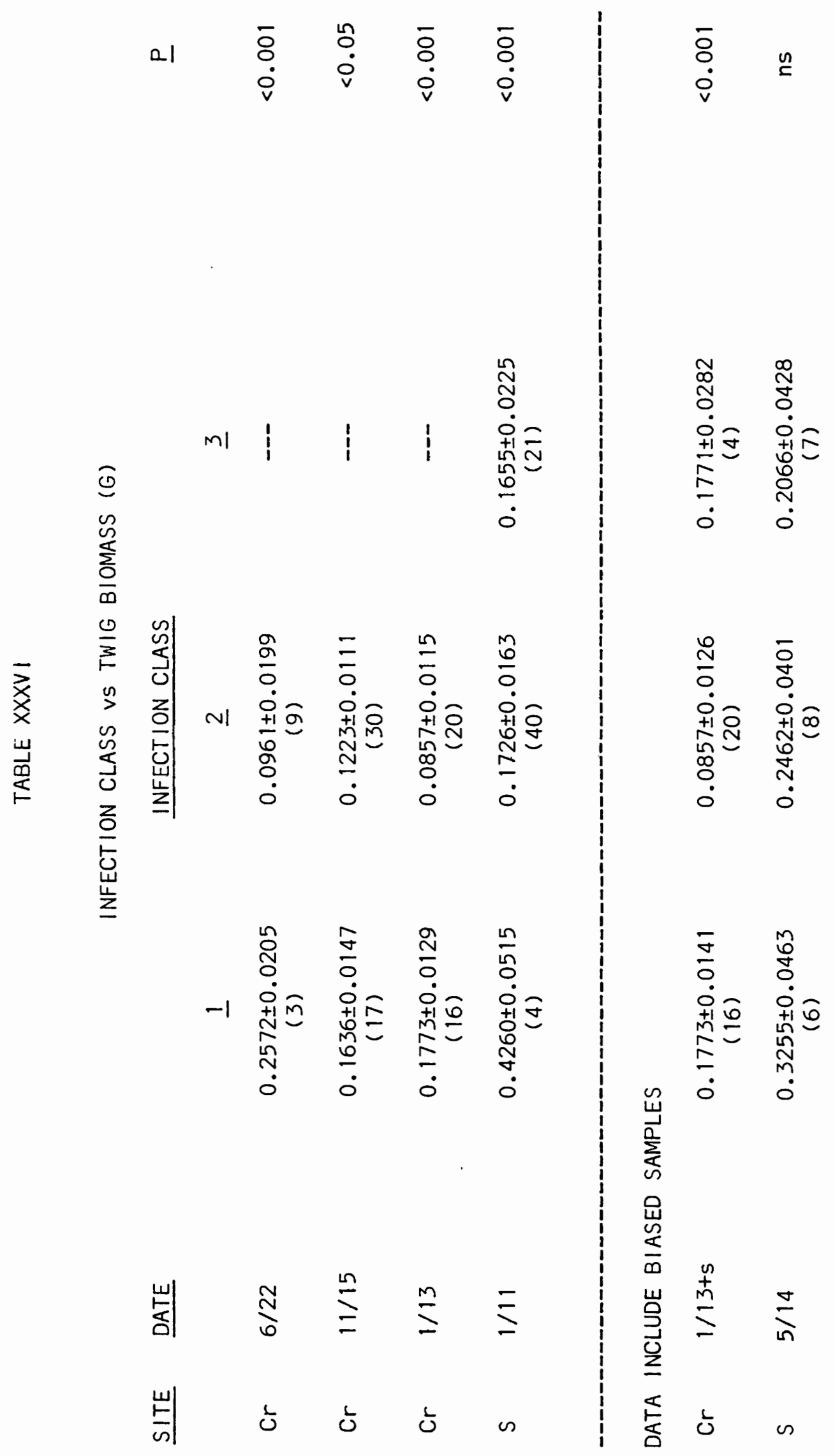




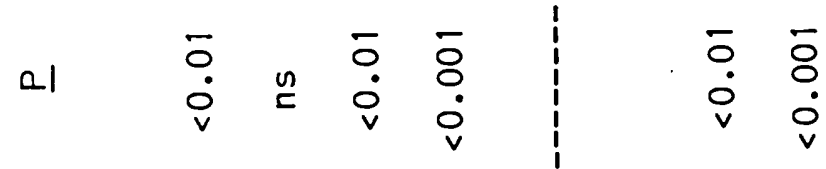

$$
\begin{aligned}
& \text { ฮ }
\end{aligned}
$$

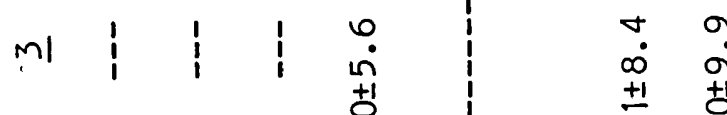

$$
\begin{aligned}
& \pm \text { 茾 } \\
& \dot{\forall} \dot{\sigma} \\
& \text { Ð } \\
& \stackrel{\infty}{\infty} \stackrel{\sim}{\sim} \\
& \pm \text { 항. } \\
& \text { in }
\end{aligned}
$$

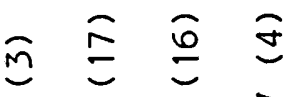

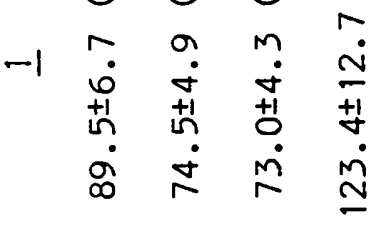

$$
\begin{aligned}
& \text { 응 } \\
& \stackrel{\sim}{\circ} \stackrel{0}{\circ}
\end{aligned}
$$

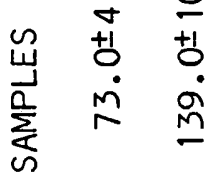

$$
\begin{aligned}
& \text { 忌 }
\end{aligned}
$$

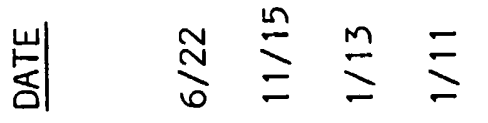

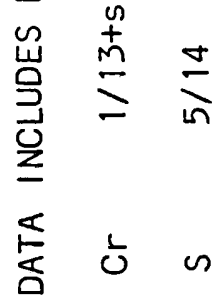

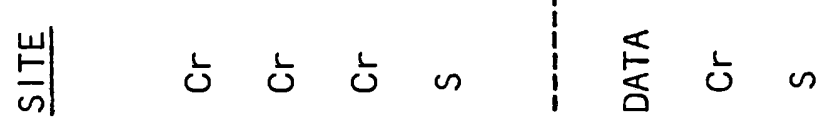




$$
\begin{aligned}
& \text { Q } \\
& \stackrel{n}{0} \stackrel{n}{\ln }
\end{aligned}
$$

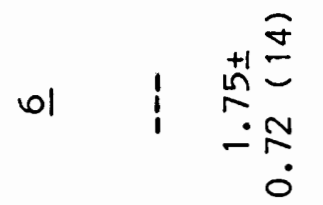

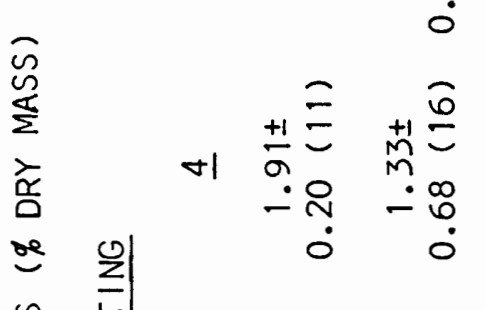

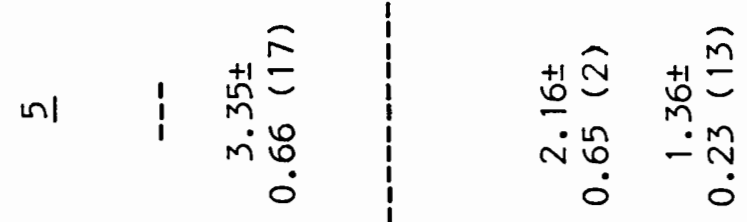

$$
\begin{aligned}
& \text { v }
\end{aligned}
$$

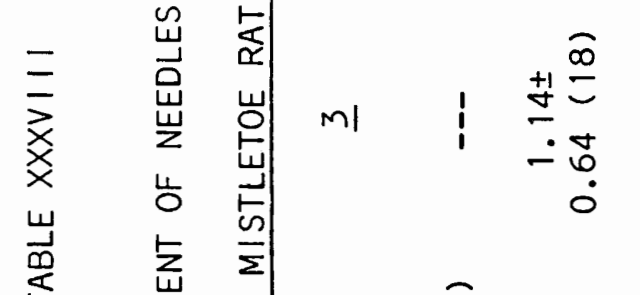

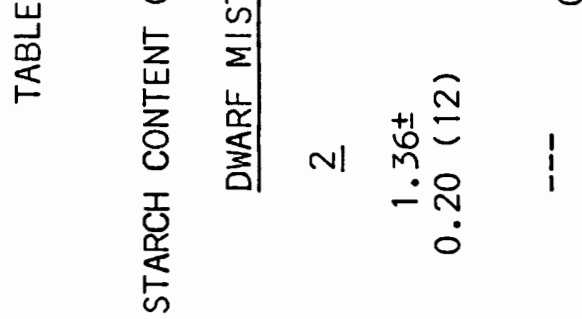

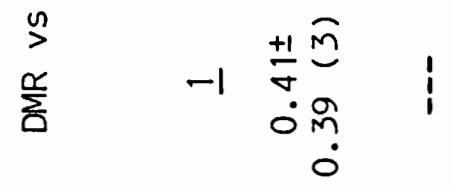

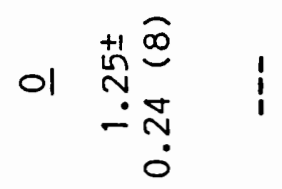

$$
\begin{aligned}
& \text { 빟ำ }
\end{aligned}
$$

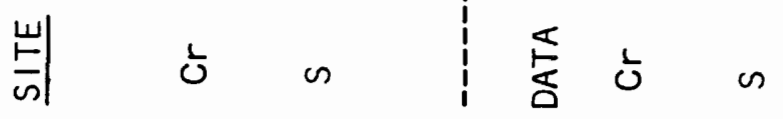




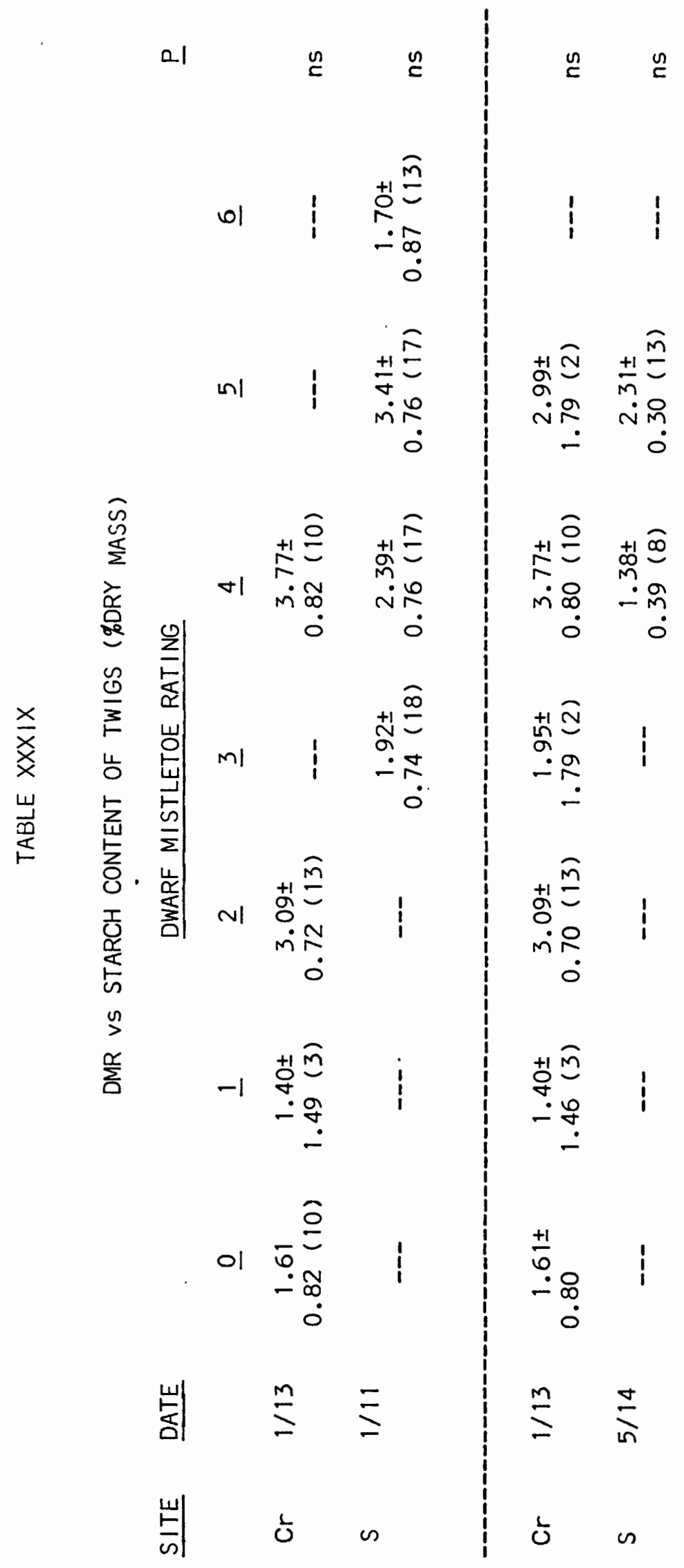




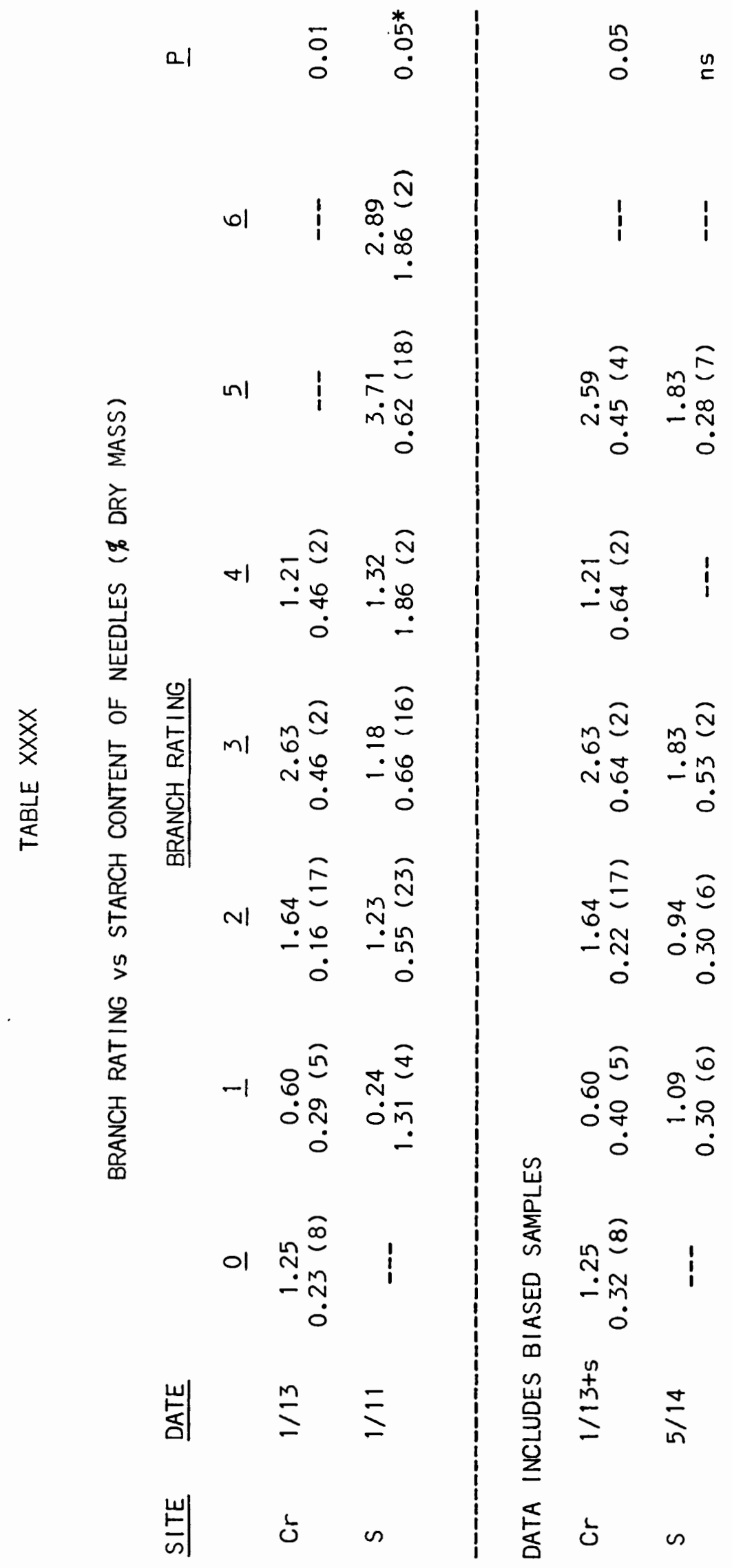




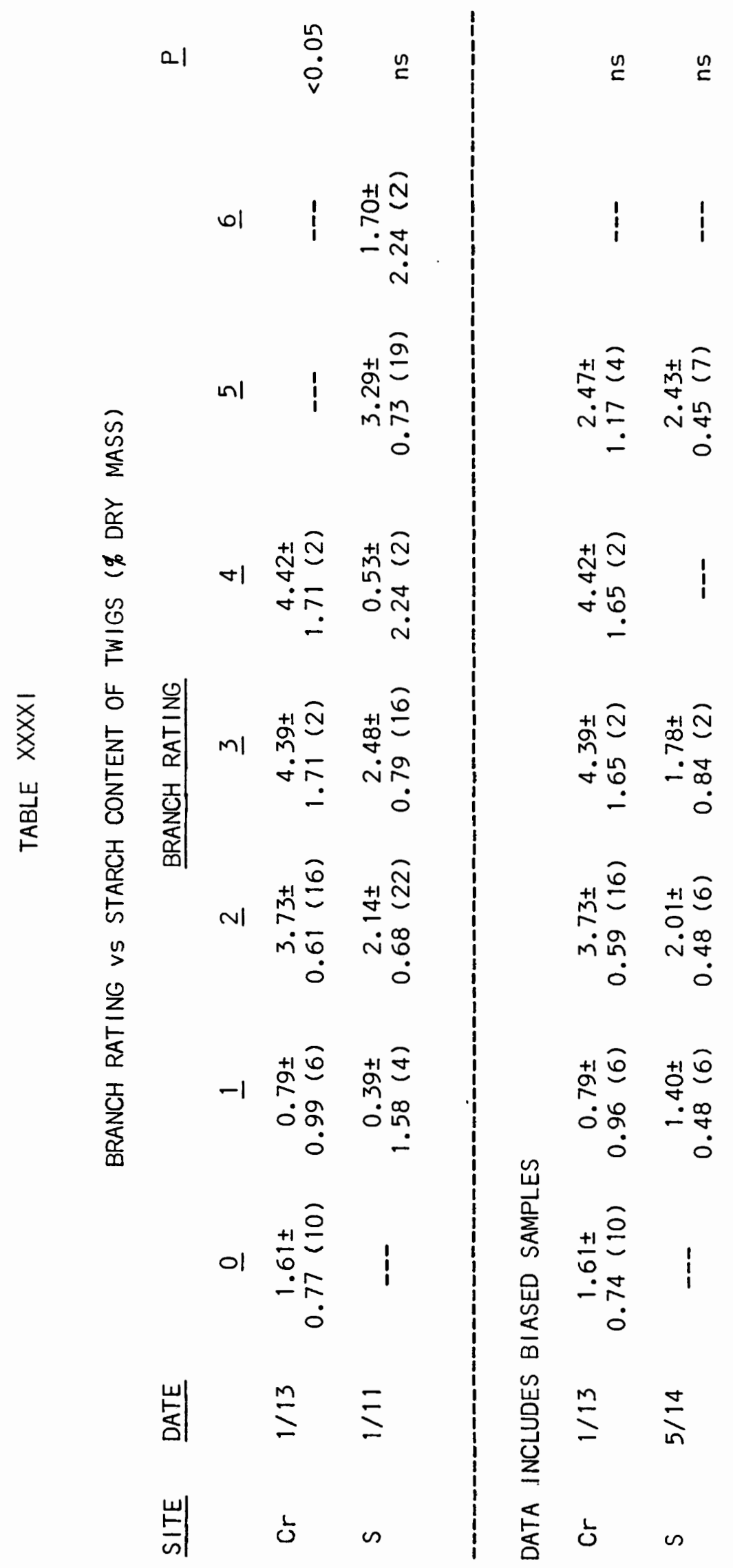




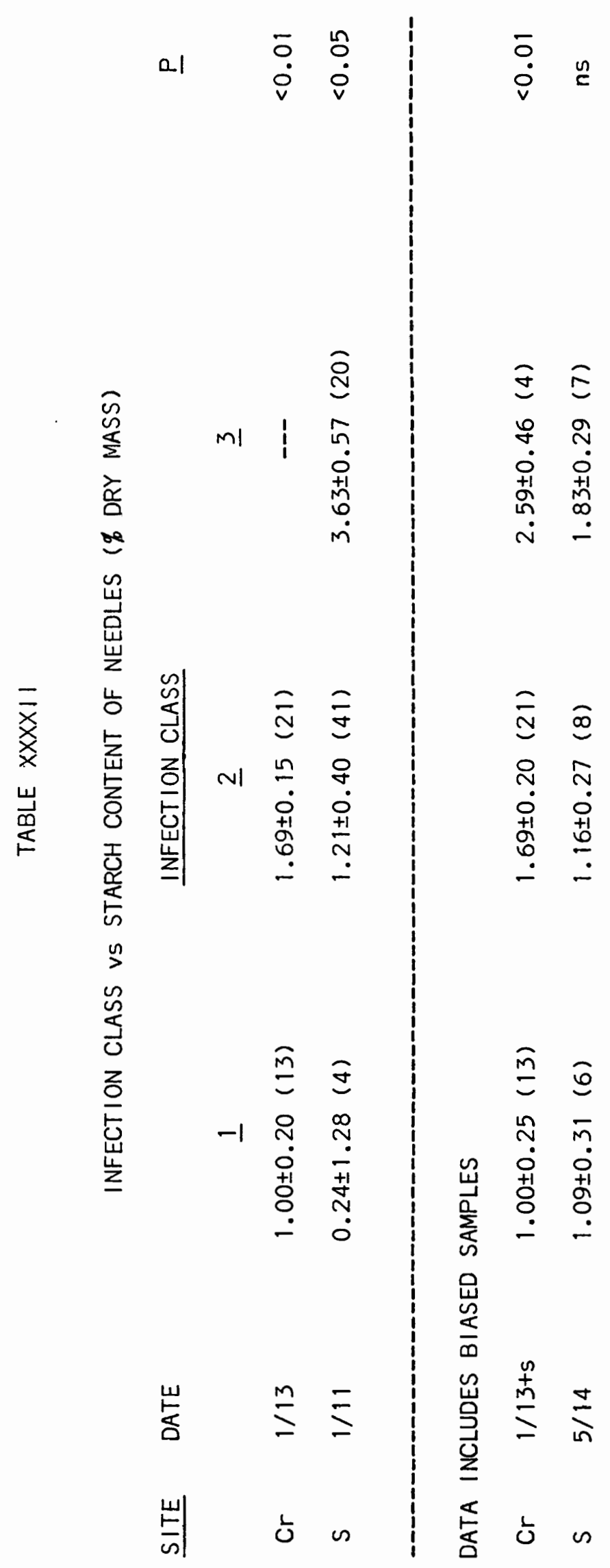




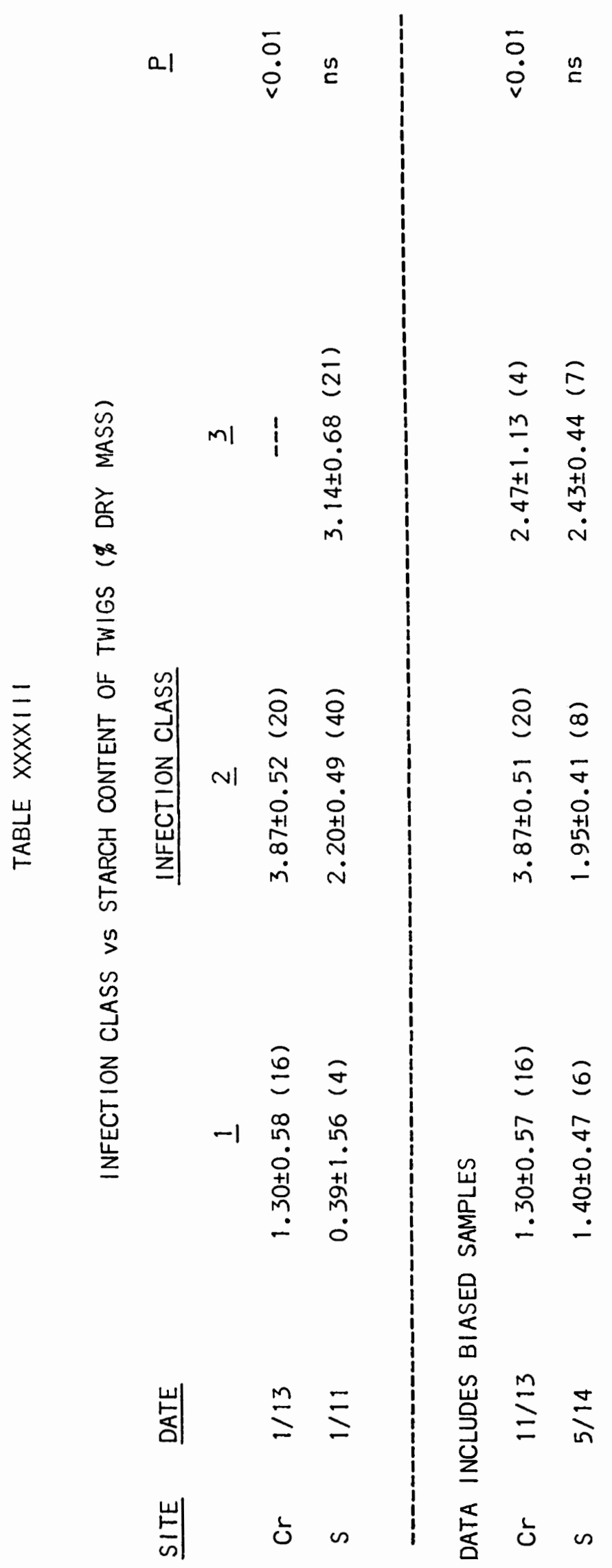

